\title{
Micro-and macro-plastics in marine species from Nordic waters
}

Bråte, Inger Lise N.; Huwer, Bastian; Thomas, Kevin V.; Eidsvoll, David P. ; Halsband, Claudia; Almroth, Bethanie Carney ; Lusher, Amy

Link to article, DOI:

10.6027/TN2017-549

Publication date:

2017

Document Version

Publisher's PDF, also known as Version of record

Link back to DTU Orbit

Citation (APA):

Bråte, I. L. N., Huwer, B., Thomas, K. V., Eidsvoll, D. P., Halsband, C., Almroth, B. C., \& Lusher, A. (2017). Micro-and macro-plastics in marine species from Nordic waters. Nordic Council of Ministers. TemaNord No. 2017:549 https://doi.org/10.6027/TN2017-549

\section{General rights}

Copyright and moral rights for the publications made accessible in the public portal are retained by the authors and/or other copyright owners and it is a condition of accessing publications that users recognise and abide by the legal requirements associated with these rights.

- Users may download and print one copy of any publication from the public portal for the purpose of private study or research.

- You may not further distribute the material or use it for any profit-making activity or commercial gain

- You may freely distribute the URL identifying the publication in the public portal 
(1I) Nordic Council of Ministers

\section{Micro-and macro-plastics in marine species from Nordic waters}





\section{Micro-and macro-plastics in marine species from Nordic waters}

Inger Lise N. Bråte, Bastian Huwer, Kevin V. Thomas, David P. Eidsvoll, Claudia Halsband, Bethanie Carney Almroth and Amy Lusher

TemaNord 2017:549 
Micro-and macro-plastics in marine species from Nordic waters

Inger Lise N. Bråte, Bastian Huwer, Kevin V. Thomas, David P. Eidsvoll, Claudia Halsband,

Bethanie Carney Almroth and Amy Lusher

ISBN 978-92-893-5118-8 (PRINT)

ISBN 978-92-893-5120-1 (PDF)

ISBN 978-92-893-5119-5 (EPUB)

http://dx.doi.org/10.6027/TN2017-549

TemaNord 2017:549

ISSN 0908-6692

Standard: PDF/UA-1

ISO $14289-1$

(c) Nordic Council of Ministers 2017

Cover photo: unsplash.com

Print: Rosendahls

Printed in Denmark

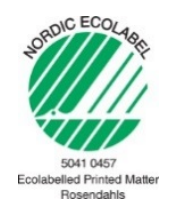

Disclaimer

This publication was funded by the Nordic Council of Ministers. However, the content does not necessarily reflect the Nordic Council of Ministers' views, opinions, attitudes or recommendations.

Rights and permissions

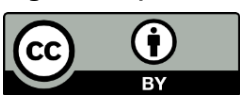

This work is made available under the Creative Commons Attribution 4.0 International license (CC BY 4.0) https://creativecommons.org/licenses/by/4.o.

Translations: If you translate this work, please include the following disclaimer: This translation was not produced by the Nordic Council of Ministers and should not be construed as official. The Nordic Council of Ministers cannot be held responsible for the translation or any errors in it.

Adaptations: If you adapt this work, please include the following disclaimer along with the attribution: This is an adaptation of an original work by the Nordic Council of Ministers. Responsibility for the views and opinions expressed in the adaptation rests solely with its author(s). The views and opinions in this adaptation have not been approved by the Nordic Council of Ministers.

Third-party content: The Nordic Council of Ministers does not necessarily own every single part of this work. The Nordic Council of Ministers cannot, therefore, guarantee that the reuse of third-party content does not in- 
fringe the copyright of the third party. If you wish to reuse any third-party content, you bear the risks associated with any such rights violations. You are responsible for determining whether there is a need to obtain permission for the use of third-party content, and if so, for obtaining the relevant permission from the copyright holder. Examples of third-party content may include, but are not limited to, tables, figures or images.

\section{Photo rights (further permission required for reuse):}

Page 26, figure 3: Data originally from Kuhn et al. 2015. Adopted by GRID-Arendal (2016).

Page 36, figure 4: Photo: Bo Eide.

Page 40, figure 6: Photo: Fredrik Myhre.

Page 41, figure 7: Photo: Eric Fokke.

Page 42, figure 8: Photo: Bo Eide.

Any queries regarding rights and licences should be addressed to:

Nordic Council of Ministers/Publication Unit

Ved Stranden 18

DK-1061 Copenhagen $\mathrm{K}$

Denmark

Phone +4533960200

pub@norden.org

\section{Nordic co-operation}

Nordic co-operation is one of the world's most extensive forms of regional collaboration, involving Denmark, Finland, Iceland, Norway, Sweden, and the Faroe Islands, Greenland and Åland.

Nordic co-operation has firm traditions in politics, economics and culture and plays an important role in European and international forums. The Nordic community strives for a strong Nordic Region in a strong Europe.

Nordic co-operation promotes regional interests and values in a global world. The values shared by the Nordic countries help make the region one of the most innovative and competitive in the world.

\section{The Nordic Council of Ministers}

Ved Stranden 18

DK-1061 Copenhagen K, Denmark

Tel.: +453396 o200 www.norden.org

Download Nordic publications at www.norden.org/nordpub 


\section{Content}

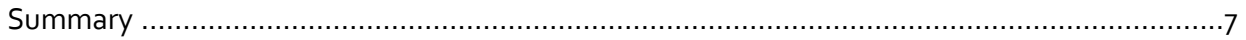

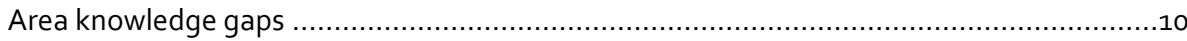

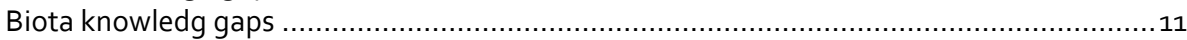

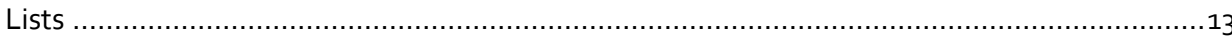

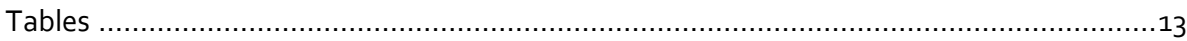

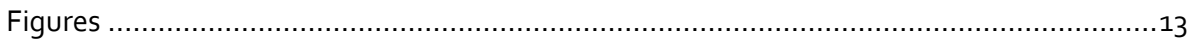

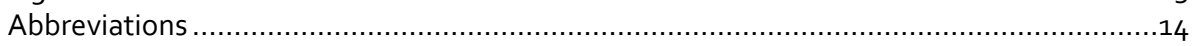

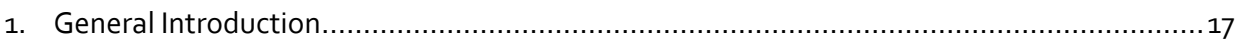

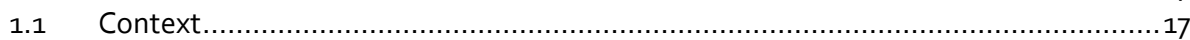

1.2 Definitions used ......................................................................................... 19

1.3 Purpose and target audience of the report .................................................. 20

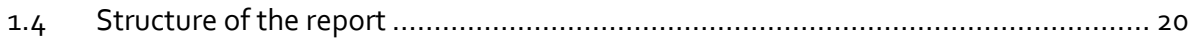

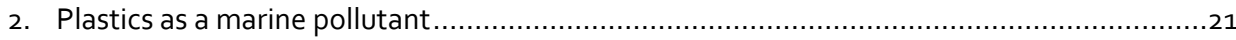

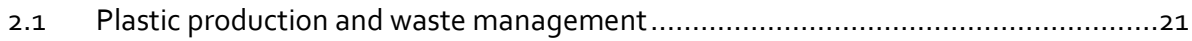

2.2 Route of entry for plastics into the marine environment .................................... 22

2.3 Distribution of plastics in the marine environment and biota .............................. 24

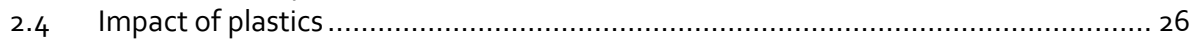

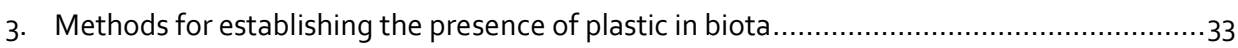

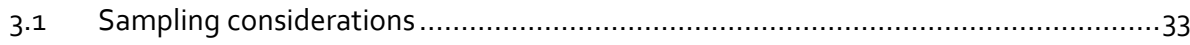

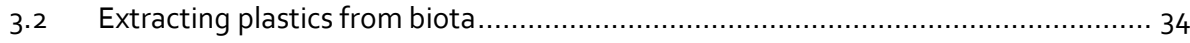

3.3 Methods for identifying plastics extracted from biota samples ............................

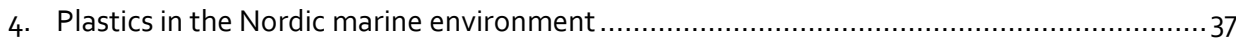

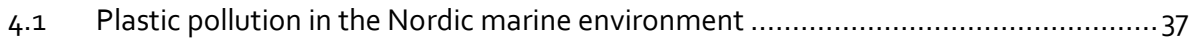

4.2 Plastic ingestion in Nordic Marine biota.................................................. 43

4.3 Factors influencing microplastic ingestion in marine biota - Comparability of studies

(a)

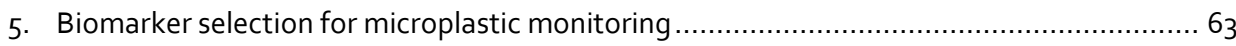

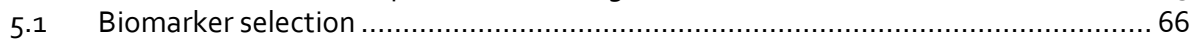

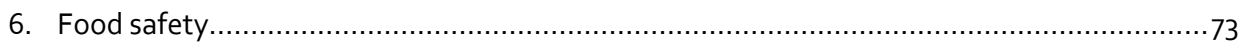

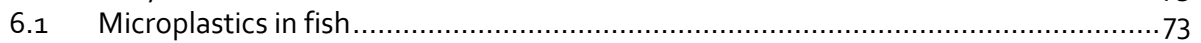

6.2 Microplastics in shellfish and crustaceans .................................................... 73

6.3 Uptake of microplastics into humans from food ............................................

7. Main knowledge gaps on plastics within Nordic Marine biota ....................................75

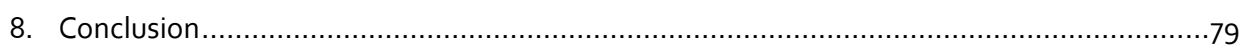

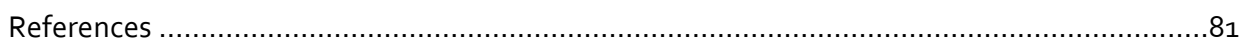

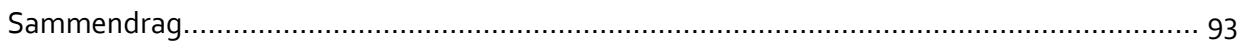

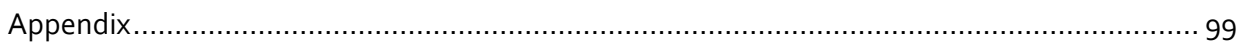





\section{Summary}

Concerns regarding marine pollution as an environmental issue has fuelled research and driven the development of international directives to preserve and maintain good environmental status. Plastics are the largest and most discussed components of marine litter. This document will discuss two types of plastic items, macroplastics and microplastics, the former being large visible items of plastics and the latter being smaller than $5 \mathrm{~mm}$ in size.

Plastic items can be made from different polymers and additive chemicals which makes them a versatile material with many different uses. The main applications in the EU include packaging and building and construction. Global production of plastics reached 322 million tonnes in 2015 and plastic production, and mass consumption, ultimately results in waste products when items reach their end of use. If discarded plastics escape waste collection schemes or are deliberately disposed of into the environment, they become debris. Plastics have been identified in terrestrial, freshwater estuarine and marine environments worldwide.

There are several sources and pathways for plastics to reach the marine environment e.g. riverine transport from land, or loss at sea from fishing vessels. Plastics are found throughout the marine environment, from urban beaches and highly polluted coastal waters to remote locations including isolated islands, the deep seafloor, and polar regions. Large plastic items, collectively known as macroplastics, are visibly noticeable and can be seen littering shorelines and floating in surface waters. Microplastics have been documented in every habitat of the open-ocean and enclosed seas, including beaches, surface waters, the water column, and the deep seafloor. Due to their small size however, it is harder to identify than macroplastics.

Impacts of plastic on the environment include habitat damage, provision of additional habitats and substrates for settling organisms, transport vectors for nonnative species through adherence to floating litter, entanglement, and ingestion of plastics by biota.

Marine organisms interact with microplastics in several ways and interactions can lead to a suite of negative effects or potential effects which have been monitored under laboratory studies. However, for wild biota there is still no documented link in between microplastic interaction and negative consequences. Marine organisms are impacted by several environmental stressors in addition to microplastics, such as increased temperature and other pollutants. Therefore, it is not possible to consider microplastics as the only reason for a negative effect. If a small organism contains significant amounts of microplastics, in relation to their size, it is likely that this could have a negative impact on growth or development; for example, affecting their ability to get sufficient amounts of food. Ingestion of microplastics could also lead to transfer of adsorbed chemicals into organisms. However, the latter is heavily debated, and several researchers claims that 
the plastic pathway for hazardous chemicals are small when compared to other routes of exposure, e.g. prey. This is still though a lot of ongoing science on this topic, and more answers will come with new research.

There are many different methods used for establishing the presence of plastics in biota, and method development is still ongoing. Sampling considerations should include replicability, comparability, contamination control and consider environmental conditions when sampling. Methods of extraction include e.g. visual dissection of digestive tracts and through dissolving digestive tract contents with chemicals such as potassium hydroxide $(\mathrm{KOH})$. Once plastics have been extracted they can be assessed based on visible observations of their morphological characteristics, and using analytical techniques to determine the chemical characteristics of polymers.

Plastics pollute the Nordic Marine Environment despite the comparatively good waste handling systems of Norway, Sweden, Denmark, Finland, and Iceland. For the Nordic region, plastics are found on beaches, at the sea surface, in the water column, at and in sediment and even in sea ice. Several organisations are involved in beach cleaning and increasing public awareness of plastics in the Nordic marine environment. In general, the Nordic environment is different from other geographical areas, regarding for example the colder climate.

Most historical data of plastic ingestion in the Nordic marine environment comes from long term monitoring studies of sea birds. There are also intermittent reports of plastic ingestion by marine mammals in the Nordic marine environment, however this data is just qualitative. In recent years, the awareness of ingestion by fish and invertebrates has increased. Most available literature of plastic in fish and invertebrates from the Nordic biota are from reports, there are only four peer-reviewed publications. Specifically, there are nine studies which have looked at 14 different fish species, most of which were conducted in the Baltic Sea and the North Sea. These fish species are:

Herring (Atlantic and Baltic), Atlantic cod, European sprat, European flounder, Atlantic mackerel, Three-spined sticklebacks, Common dab, Gray gurnard, Whiting, Horse mackerel, Haddock, European eelpout, Long-spined bullhead and Twaite shad.

These species are pelagic or demersal species from coastal and offshore locations. Herring and Cod are the most studied species by number and by study location. Percentage ingestion ranged from $0-30 \%, 13-47 \%$ and $0-31 \%$ in herring, cod, and mackerel, respectively.

There are very few studies of microplastic ingestion by bivalves and other invertebrates in the Nordic marine environment. Blue mussels are the most studied invertebrate with four studies and a total of 205 individuals from Denmark, Sweden, Skagerrak, and Svalbard. Currently, only one study with five individuals exists on the presence of microplastics in biota from aquaculture in the Nordic environment. A total of three studies exist on deposit feeding invertebrates, and plastics were found in marine worms from the North Sea, snow crabs from the Barents Sea and in Chinese mitten crab from the Baltic Sea. There are also unpublished reports of plastics found in faeces from brittle stars and polychaetes in Swedish waters.

Comparability between and within studies from the Nordic environment and other regions, are difficult as there are 1) a limited number of studies, 2) limited number of 
studies on the same species from different location and, 3) different methods used. Several other factors can also impact the level of plastic ingestion in species, especially for fish. Species ecology may affect their chance of interaction with plastics, for example, demersal species may be more exposed to settled plastics than those feeding in the water column which is a transition zone for plastics. Uptake could also be related to distance from urbanised locations, distance from sources of input or source of accumulation. Trophic level, age, size, and spawning cycle of organisms may also have an impact on plastic ingestion. In addition, stomach fullness (time since feeding) may affect the number of plastics recorded, giving us only a "snap-shot" in time when analysing fish.

To understand the impact plastic pollution has on biota, it is important to monitor ingestion and subsequent effects. Therefore, so-called biomarkers or bioindicators may be used to monitor the impacts of plastics on biota. When discussing selection of a suitable fish species for the Nordic environment, there are a limited empirical data to provide sufficient species recommendations. It is therefore proposed that Nordic countries screen several fish species and increase the number of individuals, both from pelagic and demersal environments to get a better overview on the levels of plastic ingestion. However, it is imperative to do so with comparable methods. Cod, herring and mackerel, one demersal and two pelagic species, are abundant and commercially important within Nordic countries and should be assessed for further research. Bivalves fulfil many of the criteria required for a biomonitor species, and some of the main advantages over fish is that they are sessile and much easier to process with more standardised methods available. Blue mussels have been suggested for monitoring microplastics because they have a clearly defined ecological niche and are abundant throughout the Nordic environment, as well as being used for other monitoring studies. Since benthic sediment may be a sink for plastic pollution, benthic dwelling organisms, particularly marine worms, have the potential for monitoring plastics. Arenicola marina is suggested as a suitable species because it is already used for biomonitoring and is abundant in the marine environment, and laboratory studies have already shown individuals are affected by microplastic exposure.

From a food safety perspective, the presence of microplastics in products sold for consumption raises concern for human dietary exposure. Microplastics have been found in fish and shellfish sold for human consumption, some of them, such as blue mussels, are consumed whole. Consuming food items contaminated by microplastics may facilitate the transfer of plastics-associated chemicals to humans. Current expert reviews suggest that microplastics in fish and shellfish pose negligible risk to human health. However, there are still a lot of uncertainties around plastic and food-safety, for example are the effects of nanoplastics still unknown. However, for food safety, it is necessary to establish the levels present in different commercially important biota, and also to understand what risks this could have for humans, which are currently unclear.

There are several large knowledge gaps regarding the ingestion of microplastics in Nordic marine biota, both geographically but also regarding different phyla of biota investigated. The most studied areas are the North Sea and the Baltic Sea, with few studies in Skagerrak, Kattegat and northern Norway. There are also few studies from 
the sea areas west and north of the Faroe Islands, including areas around Iceland and Greenland. For the vast majority of the west and the north of the Nordic environment, few studies exist.

Seabirds from the Nordic marine environment are used to monitor plastics down to $1 \mathrm{~mm}$ in size. However, there are no data on microplastics smaller than $1 \mathrm{~mm}$. Therefore, monitoring of microplastics smaller than $1 \mathrm{~mm}$ should also be included for seabirds.

For fish, there are some data on ingestion of microplastics in pelagic and demersal fish species, but there is a limited understanding about and the possible effects in the Nordic environment. There is a need to increase the amount of data for the different fish species using standardised methods so that it is possible to make accurate comparisons between studies. There are also no data on earlier developmental stages of fish which should be further investigated.

Currently there is no information on phytoplankton or zooplankton on ingestion or other interactions with microplastics from the Nordic marine environment. It is important to study organisms from lower trophic levels because of their position in the food web. Additionally, there are no data from studies investigating cnidarian, sponges, or corals. Since a lot of the microplastics in the marine environments are possibly associated with the sediments, it is also important to study sediment dwelling organisms. Very little information is available on marine worms with only a few preliminary studies being conducted with Arenicola marina. For the arthropods, there are also limited data available and there is a requirement to understand the effects of microplastics on crustaceans. For the bivalves, there are some studies on blue mussels, but we still need more information to establish whether they can be a useful species for biomonitoring. In addition to the blue mussels, which are filter feeders, there are many other important bivalve species that have different feeding mechanisms, and therefore can contribute to a broader understanding on plastic exposure to this group of organisms. No information is available on gastropods or cephalopods. Furthermore, there is insufficient knowledge on microplastics in marine mammals from the Nordic marine environment and since they are at the top of the food chain they could be indicators of whether trophic transfer occurs.

\section{Area knowledge gaps}

- North Sea and the Baltic Sea are the most studied areas.

- Few studies have been carried out in Skagerrak, Kattegat, and north in the Nordic marine environment. There are also very few studies from the sea areas west and north of the Faroe Islands, including areas around Iceland and Greenland. 


\section{Biota knowledge gaps}

- Organization of discussion forums to discuss suitable methods for monitoring microplastic ingestion in biota. In addition to discuss suitable methods, the focus should also be on dealing with biases such as stomach fullness, subjectivity of methods, internal laboratory.

- Quality controls ("buddy checks" etc.), contamination control and so on;

- Method development to lower the detection limit. Current methods have a detection limit at typically 200 to $100 \mu \mathrm{m}$.

- Harmonization and standardization of methods used to biota for plastic ingestion.

- Inter-calibration between laboratories with e.g. ring test to learn about interlaboratory variation.

- Identification of suitable monitoring species for different habitats. For example, identification of pelagic and benthic species from coastal and offshore locations.

- Increase number of phyla studied for microplastic ingestion from the Nordic marine environment.

- Obtain information of ingestion in species from lower trophic levels in the Nordic marine environment.

- Obtain information on ingestion of microplastics by higher trophic levels (expect for sea birds).

- Increase the number of studies of all phyla already investigated to some extent, especially for invertebrates.

- Study microplastic ingestion in same species with comparable methods for different areas to investigate spatial trends.

- Monitoring schemes should have methods adapted to include smaller microplastics. For example, the lower size limit is currently $1 \mathrm{~mm}$ for monitoring Northern fulmars under OSPAR.

- Studies of biota from more locations in the Nordic marine environment are required to better understand the interaction and ingestion of microplastics. 



\section{Lists}

Tables

1. Common plastic materials density, market demand and examples.

2. Presence of microplastics in the most important commercial species of fish.

3. Steps to minimise biases for biota being assessed for plastic contamination.

4. Categories used when classifying microplastics by shape.

5. Data collected for fish from the Nordic environment.

6. Data collected for invertebrates from the Nordic environment.

7. Habitat information on fish species found to contain plastics in the Nordic area.

8. Methods to detect plastics in the marine biota from the Nordic environment.

9. Suitability for groups of species to act as a bioindicators/biomonitor.

10. Suitability for groups of species to act as a bioindicators/biomonitor continues.

11. Knowledge gaps regarding areas defined as Nordic marine environment.

12. Microplastic knowledge gaps regarding phyla from Nordic marine environment.

13. Study ID corresponds to figures 4.10-4.14.

\section{Figures}

1. Study area defined as the "Nordic marine environment".

2. Sources and routes of transport for plastics in the marine environment.

3. Ingestion of plastics in different marine species.

4. Photo of plastic pollution in the Nordic environment.

5. Photo of car tire particle found in sediment from a Norwegian freshwater river.

6. Photo of plastic pollution on Nordic sea floor.

7. Photos of plastic interaction with Nordic biota (birds and seal).

8. Photo of plastic interaction with Nordic biota (birds).

9. Photo of plastic ingestion for Nordic biota (found in dolphin).

10. Pie chart no. of studies on plastic ingestion in biota from the Nordic marine environment.

11. Pie charts with the different fish species studied for microplastic ingestion in the Nordic marine environment. 
12. Boxplot with $\%$ of microplastic ingestion for fish from the Nordic marine environment.

13. Map with microplastic studies in herring from the Nordic marine environment.

14. Map with microplastic studies in cod from the Nordic marine environment.

15. Map with microplastic studies in pelagic fish from the Nordic marine environment.

16. Map with microplastic studies in demersal fish from the Nordic marine environment.

17. Map with microplastic studies in invertebrates from the Nordic marine environment.

18. Pie chart with polymers found in cod from the Norwegian coast.

19. Photo of polymers found in cod from Bergen city harbour.

\section{Abbreviations}

ABS Acrylonitrile butadiene styrene.

ALDFG Abandoned, lost or otherwise discarded fishing gear.

AMAP Arctic Monitoring Assessment Programme.

DAPSTORM Integrated Database and Portal for Fish Stomach Records.

DMS Dimethyl sulphide.

EcoQos The OSPAR system of Ecological Quality Objectives.

EFSA European Food Safety Authority.

EPS Expanded polystyrene.

FAO Food and Agriculture Organization.

FTIR Fourier transform infrared spectroscopy.

FTIR-ATR Fourier transform infrared spectroscopy - Attenuated total reflection.

GC/MS Gas Chromatography Mass Spectrometry.

GES Good environmental status.

GESAMP joint Group of Experts on the Scientific Aspects of Marine Pollution.

GIT Gastrointestinal tract.

HELCOM the Baltic Marine Environment Protection Commission.

ICES The International Council for the Exploration of the Sea.

$\mathrm{KOH} \quad$ Potassium hydroxide.

MARPOL International Convention for the Prevention of Pollution from Ships.

MSFD Marine Strategy Framework Directive.

NGOs Non-Governmental Organisations. 
OSPAR the Convention for the Protection of the Marine Environment of the North East Atlantic.

PA Polyamide or Nylon.

PBTs Persistent, Bio-accumulative and Toxic Substances.

PE Polyethylene (PE-HD high density, and PE-LD: low density).

PET Polyethylene terephthalate.

POPs Persistent Organic Pollutants.

PP Polypropylene.

PS Polystyrene.

PTFE Polytetrafluoroethylene.

PUR Polyurethane.

PVC Polyvinyl chloride.

PYR-GC-MS Pyrolysis-gas chromatography-mass spectrometry.

SBR Styrene-butadiene or styrene-butadiene rubber.

UNEA United Nations Environment Assembly.

UNEP United Nations Environment Programme.

WWTP Wastewater treatment plant. 



\section{General Introduction}

Abstract: Plastics are the largest and most discussed components of marine litter. This report will synthesise the current knowledge status and understanding of plastics in biota. For this report, the study area is defined as the "Nordic marine environment" which includes: The Norwegian Sea, Greenland Sea, the Norwegian and Danish sector of the North Sea, Skagerrak and Kattegat as well as the Baltic Sea. It also includes all sea areas close to Greenland (south, east and north), sea areas north and north-east of Svalbard, and coastal sea areas north-east of Varangerhalvøya.

\subsection{Context}

Marine environmental pollution takes many forms. Marine litter is recognized stakeholders as an environmental issue, and is included in international directives to preserve and maintain good environmental status (GES). For example, the EU Marine Strategy Framework Directive (MSFD 2008/56/EC) includes 11 qualitative descriptors for how countries should achieve or maintain GES in the marine environment by 2020 (European Commission, 2008). Descriptor 10 is specifically focused on marine litter, of which plastics are the largest contributor and the most widely discussed component.

Since the onset of industrial manufacturing of plastics in the 1950s, plastic production has increased substantially, with the most recent global estimate for plastic production reaching 322 million tonnes in 2015 (Plasticseurope, 2016). Nowadays, almost all aspects of daily life involve plastics. In the European Union, the main applications of plastics include: packaging (39.9\%, much of which is single-use), building and construction $(19.7 \%)$, the automotive industry $(8.9 \%)$, electrical and electronics (5.8\%), agriculture (3.3\%) and other applications (22.4\%), including consumer and home appliances, furniture, sport, health and safety) (Plasticseurope, 2016). Plastic is a very popular material for use in products due to many different qualities, however its attractiveness as a durable material when combined with improper waste management practices can lead to environmental contamination on land and water. Certain plastic products will degrade over time into smaller sizes, ranging from the macroscopic to the microscopic. Laboratory studies have further shown degradation to nanoplastics (Lambert \& Wagner, 2016).

As early as the 1960 , the implications of macroplastic in the environment were discussed in the scientific community (Harper \& Fowler, 1987). However, it is only in the last decade that microplastic has received increased attention by the scientific community, international organisations, governments, and public media. This rise in interest has been primarily driven by concerns on the potential environmental and human health effects of exposure to microplastics (UNEP, 2016). 
The occurrence of plastic debris of all sizes has been detected in all environmental matrixes; surface waters, the water column, beaches, the sea floor, and selected organisms. Several reviews have been performed to assess the current state of knowledge worldwide (e.g. Galgani et al., 2015; GESAMP, 2015; GESAMP, 2016) and national and regional projects have attempted to highlight sources and sinks of plastic pollution (e.g. Hong et al., 2014; Sundt et al., 2014). The quantities and types (size, shape, density, chemical composition, colour) of plastics, together with their routes of entry to the marine environment, may determine their distribution and subsequent possible impacts. In recent years, concern has shifted towards the impacts on marine organisms that are consumed by humans or are commercially important (Lusher et al., 2017; FAO, in press).

Methods used to determine the quantities and types of plastics in the environment vary, and therefore there have been calls from the scientific community to standardise methodological approaches allowing replication and better comparability between studies. An ability to effectively compare studies utilising different methods is at the forefront of current research since there is an absence of comparable methods for microplastic and macroplastic studies (Lusher, 2015; Galgani et al., 2015). In addition, since microplastics do not behave and move as classical particle-bound environmental pollutants, and are not evenly distributed in the environment (Nuelle et al., 2014), it is a challenge to sample representative parts of different matrixes.

Plastic contamination of Nordic waters is of concern for the public, researchers, NGOs and policy makers, but little knowledge is available to help stakeholders make informed decisions regarding topics such as food safety. However, there are some published papers on findings within the water column (e.g. Lusher et al., 2015; Talvitie et al., 2015; Gewert et al., 2017) as well as ingestion in biota such as seabirds (van Franeker, 1985; van Franeker et al., 2011), fish (Skóra et al., 2012; Foekema et al., 2013; Bråte et al., 2016; Rummel et al., 2016) and invertertes (Vandermeersch et al., 2015; Wójcik-Fudalewska et al., 2016). The current data ground is small, but there are several ongoing projects on plastics in Nordic waters which have a specific focus on plastic ingestion. This report will synthesise the current knowledge status and understanding of plastics in biota. For this report, the study area is defined as the "Nordic marine environment" which includes: The Norwegian Sea, Greenland Sea, the Norwegian and Danish sector of the North Sea, Skagerrak and Kattegat as well as the Baltic Sea. It also includes all sea areas close to Greenland (south, east and north), sea areas north and north-east of Svalbard, and coastal sea areas north-east of Varangerhalvøya (Figure 1). 
Figure 1: The Nordic Environment as defined in this report inside the red marking; The Norwegian Sea, Greenland Sea, the Norwegian and Danish sector of the North Sea, Skagerrak and Kattegat as well as the Baltic Sea. It also includes all sea areas close to Greenland (south, east and north) as well as sea areas north and north-east of Svalbard, and coastal sea areas north east of Varangerhalvøya

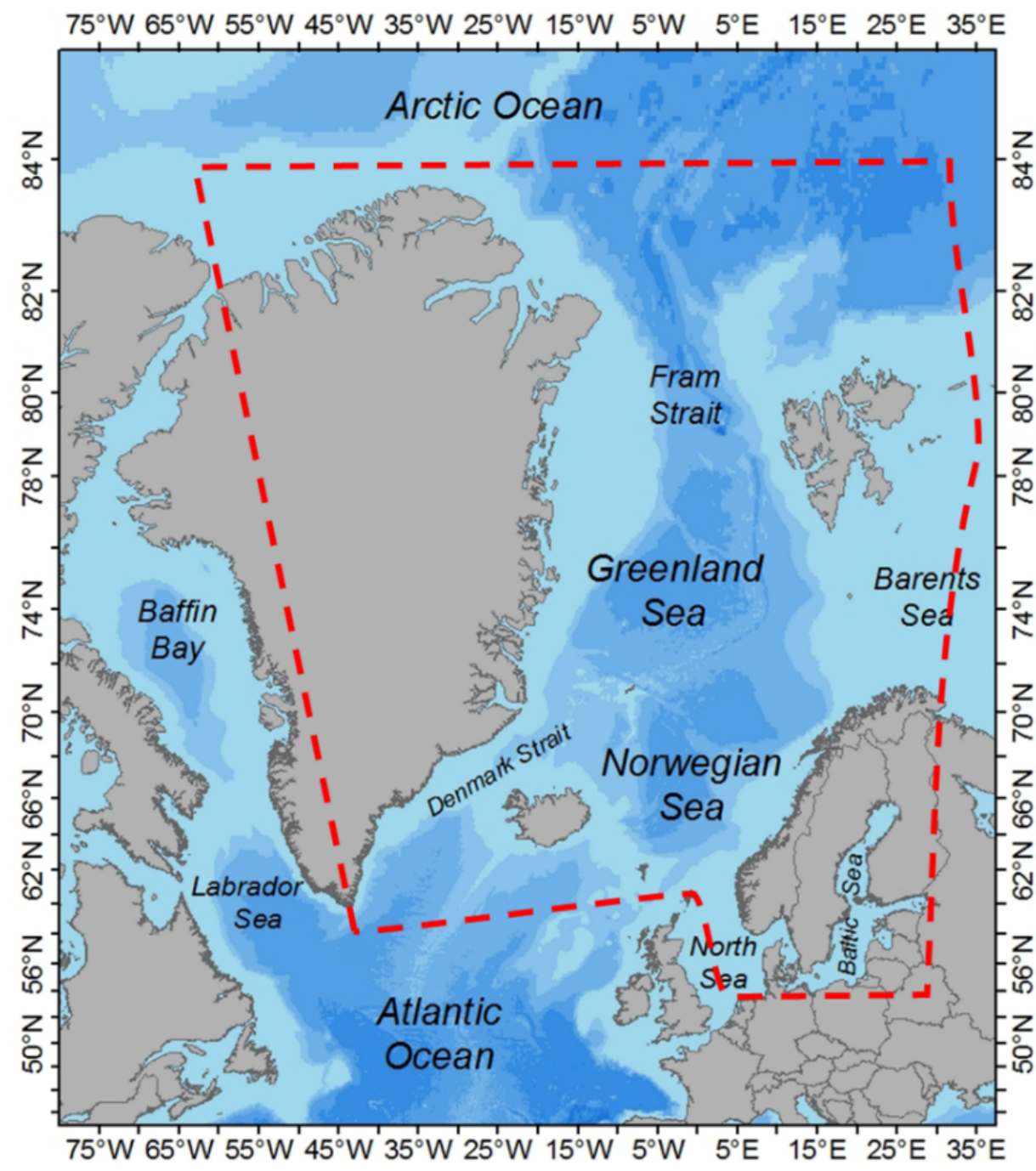

\subsection{Definitions used}

Several definitions are used to define plastic pollution. For this report, the definitions follow the standards suggested by expert working groups (GESAMP, UNEP):

- Marine litter is defined as any persistent, manufactured or processed solid material discarded, disposed of, abandoned or lost in the marine and coastal environment

- Macroplastics are large items of marine plastics that are $>5 \mathrm{~mm}$ in size. 
- Microplastics: plastic particles of size ranging between 0.1 to 5,000 micrometres $(\mu \mathrm{m})(0.0001-5.0 \mathrm{~mm})$ in their longest dimension.

- Nanoplastics: plastic particles of size ranging from 1 to 100 nanometers ( $\mathrm{nm}$ ) (0.001 $\mu \mathrm{m}-0.1 \mu \mathrm{m})$.

In the case of microplastics there has been recent debate as to whether the classification should follow SI unites ( $1 \mathrm{~mm}$ ) or adhere to the original definition of $5 \mathrm{~mm}$ (Arthur et al., 2009). Furthermore, researchers have started to use two different definitions for microplastics, smaller than $1 \mathrm{~mm}$ small microplastics and $1-5 \mathrm{~mm}$ large microplastics. Therefore, for this report we use smaller than $5 \mathrm{~mm}$ to encompass both the traditional definitions and the SI units. Additionally, nanoplastics, which have been often discussed together with microplastics, will also be included here as part of the microplastics category.

\subsection{Purpose and target audience of the report}

Marine litter in the environment, and plastics found within ecologically and commercially important organisms, may have negative consequences on marine wildlife. This creates a need for assessing how plastics in the environment create a risk for ecosystems and humans. This report summarises the current state of knowledge on the occurrence of plastics in marine species from Nordic marine waters and it aims to give policy makers and stakeholders, as well as scientific and general audiences, an overview of the knowledge available for microplastics in Nordic biota. There is a specific emphasis on microplastics as their small size increases the probability to be consumed by many species. In addition to peer-reviewed literature, the report also aims to include information from other sources such as scientific reports and unpublished data. In summary, this report provides a comprehensive overview of the current state of knowledge on plastics in biota from the Nordic environment.

\subsection{Structure of the report}

To present a comprehensive report on the current state of knowledge of the presence of plastics in the Nordic marine biota this report has seven clearly defined content sections followed conclusions and a comprehensive reference list. Firstly, a general introduction to plastics as a marine pollutant is presented. Secondly, the methods used to detect plastics in marine biota are discussed. Thirdly, current information on the presence and abundance of plastics in Nordic marine environment, with a specific focus on ingestion by biota, is discussed. Fourthly, the use of biota as monitoring tools for the Nordic marine environment are proposed. Finally, the implications for food safety and human health are described, followed by a discussion of the main knowledge gaps on plastic pollution in biota from the Nordic environment. 


\title{
2. Plastics as a marine pollutant
}

\begin{abstract}
Plastics are found throughout the marine environment, from urban beaches and highly polluted coastal waters to remote locations including isolated islands, the deep seafloor, and polar regions. Microplastics have been documented in every habitat of the open-ocean and enclosed seas, including beaches, surface waters, the water column, and the deep seafloor. Impacts of plastic on the environment include habitat damage, provision of additional habitats and substrates for settling organisms, and ingestion of plastics by biota. Marine organisms interact with microplastics in several ways and interactions can lead to a suite of negative effects or potential effects which have been monitored under laboratory studies.
\end{abstract}

\subsection{Plastic production and waste management}

Plastic is a catch-all term used to describe a group of synthetic polymers that are manufactured to have different properties (UNEP, 2016). Plastic polymers are the building blocks used to create plastics and can be mixed with different additives during manufacture to enhance their performance. Additives includes plasticizers, antioxidants, flame retardants, ultraviolet stabilizers, lubricants and colourants. Common examples of thermoplastics include polyethylene ( $P E$, high and low density), polyethylene terephthalate (PET), polypropylene (PP), polyvinyl chloride (PVC) and polystyrene (PS, including expanded EPS). Common examples of thermoset plastic materials include polyurethane (PUR) and epoxy resins or coatings. These polymers are used to make create a variety of products (Table 3, Plasticseurope, 2016).

In the European Union, the main applications of plastics include: packaging (39.9\%, much of which is single-use), building and construction (19.7\%), the automotive industry (8.9\%), electrical and electronics (5.8\%), agriculture (3.3\%) and other applications (22.4\%, including consumer and home appliances, furniture, sport, health and safety). When the market demand for materials is divided by polymer type, it is evident that low-density polyethylene (PE-LD), followed by polypropylene (PP) packaging is the most widely used material. Large-scale plastic production started in the early 1950s, when production levels were about two million tonnes per year, and by 2015 the production of plastic reached 322 million tonnes (Plasticseurope, 2016).

There are clearly many benefits from the use of plastic products; and dependence on plastic products has fuelled mass production. Obstacles arise when managing plastics which are no longer useful. This includes every step in the life cycle of plastics from spills and release at production sites, to losses during usage and at end-of-life when plastics reach their end of usefulness. Generated solid waste needs to be managed appropriately to prevent it discharging into the environment. The extent to 
which discarded plastic items reach the environment as waste, is dependent on the effectiveness of solid waste collection, management and wastewater treatment facilities but can also be affected by environmental conditions (GESAMP, 2015). Waste and recycling infrastructure may not be adequate for the volume of waste it receives or may be ineffective in areas with large urban populations. Conversely, consumers may adequately dispose of waste products with the intention of items reaching recycling or landfill facilities, but adverse weather conditions can displace items into the environment. In the case of microplastics generated from consumers, through the use of cosmetics and personal care products containing microbeads or washing synthetic clothing, small plastics can pass through wastewater treatment plants depending on the sophistication of the equipment, number of treatment stages and procedures used (Napper et al., 2015; Ziajahromi et al., 2016; Mahon et al., 2017).

There may be regional, national and international differences in the contribution of wastewater plants on the input of microplastic fibres to the environment. In addition, many researchers consider including micro litter or microscopic litter under the same banner as microplastics (Norén \& Naustvoll, 2011; Magnusson \& Norén, 2011) to include rubber particles and other polymers which may also have detrimental effects on the environment and biota. This term also includes car tire particles, road wear, and artificial turf. In Sweden for example, these types of particles are being prioritized in research schemes. Mass production, mass consumption and inadequate waste management of plastics have led to the contamination of terrestrial, freshwater, estuarine and marine environments (GESAMP, 2016). It is estimated that between 4.8 million and 12.7 million tonnes of this plastic waste has entered the world's oceans (Jambeck et al., 2015).

\subsection{Route of entry for plastics into the marine environment}

There are multiple sources and routes of entry for plastics of all sizes into the ocean although the contributions from different sources of input remain largely unknown (Figure 2). At present, it is not possible to generate reliable quantitative comparisons between plastic input loads, sources and originating sectors, and this represents a significant knowledge gap (UNEP, 2016). Attempts have been made to estimate some of the sources (e.g. Jambeck et al., 2015)). However, numbers presented in these reports should be treated with caution due to the large number of uncertainties and extrapolations involved. Land-based inputs of plastics may be direct from shorelines or via rivers and wastewater pipelines. Along with the unintentional loss of "in use plastics" to the environment through weather events, plastics may escape during the waste management process. Inputs at sea may be from normal shipping operations, accidental losses, or deliberate discarding (Figure 2). 
Figure 2: Sources and routes of transport for plastics (macro and micro) in the marine environment

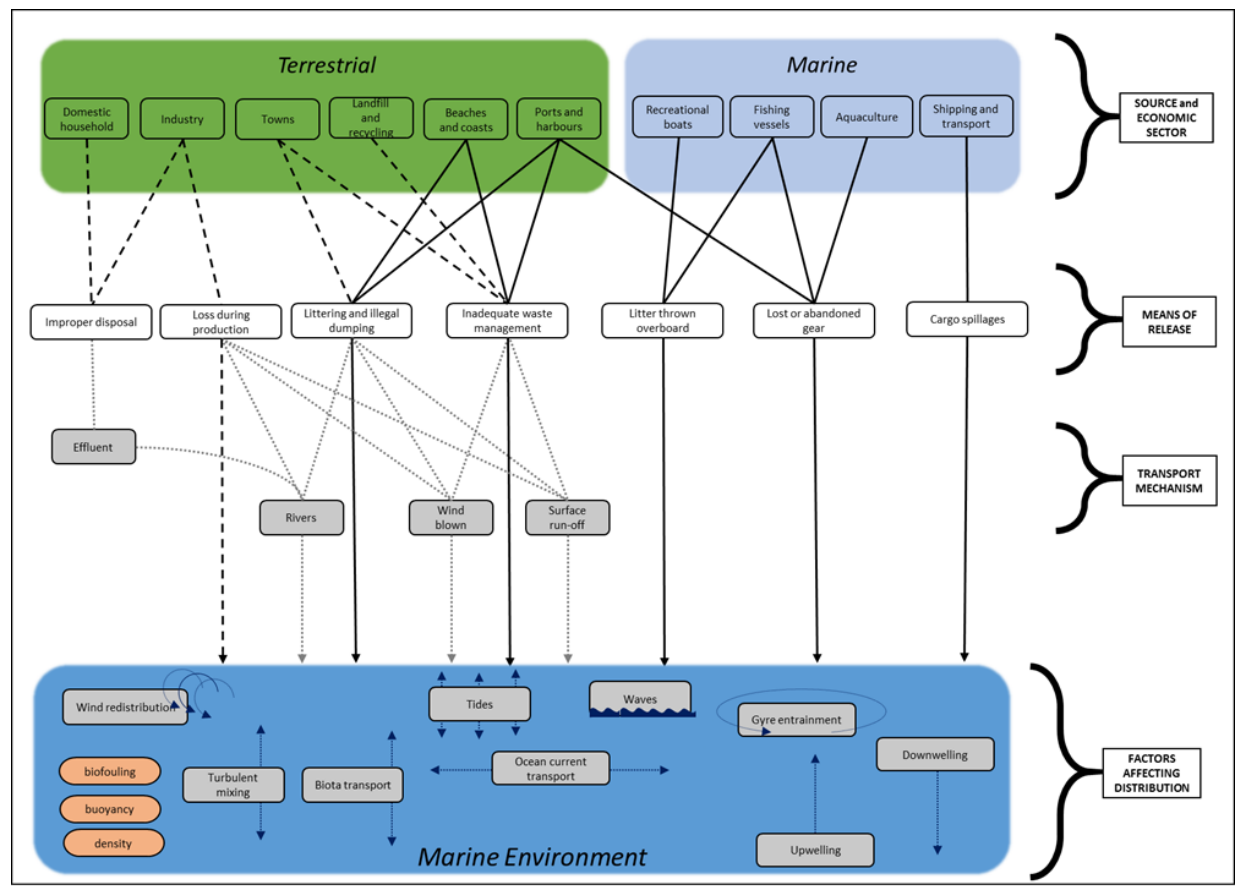

Land-based sources of macroplastics include food and drink containers, household goods, packaging, constructions and tourism. Marine-based sources of macroplastics include fisheries and shipping sectors. Abandoned, lost or otherwise discarded fishing gear (ALDFG) is considered the main source of plastic waste from fisheries and aquaculture sectors, but its relative contribution is not well known at regional and global levels (GESAMP, 2016). ALDFG tends to concentrate around fishing grounds, but can be transported considerable distances. Furthermore, aquaculture structures are primarily made of plastic materials and if structures are not maintained or are damaged by environmental conditions, they can produce significant amounts of plastic debris. Concerning shipping, the disposal of galley waste and waste materials is prohibited under MARPOL, but shipping may be responsible for loss of items during operations and through the loss of cargo in transport.

Microplastics can enter the environment in many different forms. Primary microplastics are those, which are manufactured in sizes smaller than $5 \mathrm{~mm}$, and secondary microplastics are plastics that reach the micro scale following the breakdown of larger items in the environment (Arthur et al., 2009; Cole et al., 2011). Several processes lead to the formation of microplastics for larger plastic items, including weathering, UV-degradation, oxidation and wave action (Andrady, 2011; Andrady, 2015). Therefore, microplastic pollution might increase in the near future as result of environmental breakdown and fragmentation of present stocks and future production of plastic items. Land-based sources of microplastics include: raw plastic pellets from plastic producers and fabricators, which are used in plastic manufacturing and forming larger plastic products, plastic beads and grains incorporated into cosmetics and 
personal care product, synthetic fibres from textiles and clothing, and airborne fibres and fragments from the breakdown of car tyres during use (Figure 2). Monomers and polymers are the building blocks of plastics but they can also be released from plastics as they become brittle and break down in the environment. For example, styrene monomers, dimers and trimers have all be detected in seawater and sediments from coastal regions (Kwon et al., 2015). Additives are incorporated into plastics during plastic production although the quantities used vary greatly. It is estimated that additives account for around $4 \%$ of the total weight of plastics produced (Andrady \& Neal, 2009; Lambert et al., 2014).

\subsection{Distribution of plastics in the marine environment and biota}

In the marine environment, plastics occur in all five environmental matrixes which are the beaches, surface waters and the water column, the sea floor, in sediments and in biota. Dispersal and behaviour of plastics in the marine environment can be influenced by (i) the characteristics and properties of the plastics themselves and (ii) environmental conditions which includes processes acting both within and between matrixes. Plastics have different characteristics that are dependent on the polymers used in their production. These polymer properties can influence their behaviour in the environment. For example, density relative to seawater is one of the most influential properties of plastics with respect to environmental distribution. Plastic densities range from 0.90 to $1.39(\mathrm{~kg} \mathrm{~m} \mathrm{-3)} \mathrm{(Table} 1$ ) and for plastics that are less dense than the surrounding water, will float whereas those that have a density greater than sea water will sink.

Table 1: Common plastic materials, their specific density, share of market demand and examples. These values are dependent on temperature and salinity and varies geographically and with water depth

$\begin{array}{lrll}\text { Material } & \text { Density } & \% \text { of market } & \text { Examples } \\ \text { Polyethylene (PE) } & 0.91-0.94 & \text { HD: 12.1. LD: 17.3 } & \text { Bags, bottles, fishing gear } \\ \text { Polypropylene (PP) } & 0.90-0.92 & 19.1 & \text { Ropes, bottle caps } \\ \text { Styrene-butadiene/ styrene-butadiene rubber (SBR) } & 0.94 & - & \text { Roofing and car tires } \\ \text { Pure water } & 1.00 & \\ \text { Expanded Polystyrene (EPS) } & 0.96-1.05 & \text { see PS } & \text { Bait boxes, floats, packaging } \\ \text { Seawater } & 1.02-1.029 & \\ \text { Polystyrene (PS) } & 1.04-1.09 & 6.9 & \text { Utensils, packaging } \\ \text { Acrylonitrile butadiene styrene (ABS) } & 1.03-1.11 & - & \text { Electronics, car interiors } \\ \text { Acrylic } & 1.09-1.20 & - & \text { Textiles, paints } \\ \text { Poly vinyl chloride (PVC) } & 1.16-1.30 & 10.1 & \text { Buoys, fishing gear } \\ \text { Polyamide or Nylon (PA) } & 1.13-1.15 & - & \text { Fishing ropes, textiles } \\ \text { PUR } & 1.2 & 7.5 & \text { Insulation } \\ \text { Cellulose acetate or Rayon } & 1.22-1.24 & - & \text { Textiles, cigarette filters } \\ \text { Polyethylene tetraphalate (PET) } & 1.34-1.39 & 7.1 & \text { Bottles and single use plastics } \\ \text { Polyester resins } & >1.35 & - & \text { Textiles } \\ \text { Polytetrafluoroethylene (PTFE) or Teflon } & 2.2 & - & \text { Insulating plastics }\end{array}$

Source: Adapted from Plasticseurope, 2016. 
Of all the plastics that are produced, approximately $50 \%$, by weight, of the polymers produced for Europe, float in seawater (Plasticseurope, 2016); polyethylene (PE) and polypropylene (PP) float in both freshwater and seawater while expanded polystyrene (EPS) and PE, PP float in seawater. However, inherently buoyant plastics and items that contain entrapped air will float in surface waters, as common for polystyrene. Buoyancy will also be dependent on environmental conditions such as weathering and biofouling together with water disturbance and turbulence, in addition to additives added to the polymers (Andrady, 2015).

Marine plastics are globally distributed from the Arctic to the Antarctic and everywhere in between. Run-off, currents and mixing of water layers are responsible for the fast and far-reaching movement of plastics within and between oceans and from land to sea (UNEP, 2016; GESAMP, 2015). In the open ocean, a broad pattern of persistent surface currents characterizes the circulation of oceanic waters and dominates the passive transport of floating objects. Persistent oceanic features such as accumulation zones in upwelling areas and ocean gyres can accumulate floating objects. For example, the five sub-tropical gyres in the Indian Ocean, North and South Pacific, and North and South Atlantic, are areas with relatively high concentrations of floating plastic items, including microplastics. Larger floating items can be driven by winds and accumulate on shores and remote ocean islands large distances from their sources. Coastal regions, such as those with high urban populations and tourism, inadequate waste disposal and management and intensive fisheries, tend to have high abundances of plastics. Furthermore, rivers and estuaries can influence coastal currents on a local scale.

Floating plastic debris is transported in surface waters by winds and ocean currents. Plastics may remain suspended in the water column (pelagic zone) for a long time until they sink to the seafloor or are deposited on shorelines back on land. Over time, floating litter will weather and become brittle when exposed to environmental conditions such as sea water, solar radiation and wave action (Andrady, 2011), and these items will eventually degrade into microplastics. However, weathering, biofouling, wind, wave, current, tidal action, can force plastic items to mix - at least to some extent throughout the water column.

Marine plastics are commonly found along shorelines. In the case of macroplastics, much effort has been focused on these coastal areas. However, it is difficult to compare concentrations between coastal areas as different methods and reporting units have been used, i.e. number of items per area or total weight per area. Some common patterns have emerged though, such as greater loads of debris close to urban and touristic areas (Barnes et al., 2009). Flooding and heavy weather events also increase the number of beached items found, this is due to either the increased transport of plastics from terrestrial sources or the deposition of plastics items following high tides and storms. Beach monitoring schemes provide the most comprehensive data on plastic items but currently, it is hard to quantify levels of microplastics on coastlines, although there are some examples on regional and local scales (Lusherk, 2015). Plastics are not only found at the surface but also buried on beaches (Turra et al., 2014). At 
present, the ecological impact of macro and microplastics on coastlines are unclear (GESAMP, 2016).

Marine organisms themselves act as an environmental matrix when plastics are located within their gut or various tissues. Several species of biota from different trophic levels have been found to ingest plastics (Kühn et al., 2015; GESAMP, 2016). Reasons for uptake are varied and could be a result of direct consumption including misidentification and secondary consumption from eating prey items that already contain microplastics. For more information on plastic ingestion see section 2.4 .

\section{$2.4 \quad$ Impact of plastics}

Environmental implications of plastics on marine ecosystems can range from the unsightly view of waste littering shorelines, the economic costs of clean-up operations and the visible implications of macroplastics on marine biota. Implications are very much dependent on the size of the plastic involved. The impacts of plastics which are introduced in the following section have been divided into three distinct categories the impacts on (i) the environment, (ii) biota, and (iii) the economy and society.

\subsubsection{Impact on the environment}

Large items of plastic can impact habitats. For example, ghost fishing negatively impacts marine wildlife (Stelfox et al., 2016) and ALDFG can negatively impact benthic communities. Macroplastics can also lead to anoxic conditions within the sediment (Mordecai et al., 2011; Green et al., 2015) and can thereby affect the benthic community. Plastics can also provide habitats for many species, for example can floating plastic support diverse communities of marine biota including invertebrates and microbial communities (Barnes \& Milner, 2005; Kiessling et al., 2015). Biofilm formation and colonisation of microplastics occurs because plastic surfaces absorb organic nutrients which attract microbial colonies (Oberbeckmann et al., 2015). When organisms colonise floating plastics, they can affect plastic buoyancy and degradation and its persistence in the environment. Plastic in turn facilitates the dispersal of rafting communities between ocean habitats.

\subsubsection{Impact on biota}

To compile and visualize global information sources on plastic distribution, including data of plastic ingestion, a new database, "LitterBase", has been published, hosted by the Alfred Wegener Institute (AWI), Germany. It presents a live map of known marine plastic collated from peer-reviewed publications (http://litterbase.awi.de). Through using the interactive map, users can find the amount and distribution of plastics, and plastic interaction with wildlife, ingestion, entanglement and colonization, to receive an overview of published studies. 
Macroplastic impacts on biota have been giving most attention since they are more readily portrayed by the media. Entanglement in fishing gear or household products presents a very visible problem, followed by the impacts of macroplastic ingestion, exemplified by emaciated and dead individuals.

Historically, reports of entanglement with turtles, birds and mammals has received the most attention but consequences on other species are becoming more evident as the issue of plastic pollution is highlighted, both in popular media and scientific publications. Entanglement amongst marine species varies, such that $100 \%$ of marine turtles, $67 \%$ of seals, $31 \%$ of whales and $25 \%$ of seabirds have been found affected by marine debris (Kühn et al., 2015).

\section{Ingestion}

The impact of plastic ingestion is less visible than the implications of plastic entanglement and many species are found to ingest plastics (Figure 3). Plastics may be retained in stomachs when organisms are unable to regurgitate the items through complex digestive systems (Kühn et al., 2015). Plastic may be ingested intentionally or accidently and may be related to the feeding habits of individual species (Kühn et al., 2015; Lusher, 2015). Intentional ingestion depends on factors which make plastic a target for animals during foraging, and these factors may differ between animal groups. For example, seabirds with specialized diets are unlikely to miss-identify plastics, unless a particle resembles their prey, whereas pursuit diving birds and surface-seizing may have a higher frequency of uptake (Day et al., 1985). Numerous fish species have been found to have microplastics in their gut contents, but there does not seem to be a difference in ingestion rates based on the species' niches in the environment, i.e. benthic vs pelagic, or trophic guild, i.e. herbivore, insectivore, or carnivore (Phillips \& Bonner, 2015).

Accidental ingestion could also be related to feeding mechanisms for examples, baleen whales filter large volumes of water and may be unable to differentiate between plankton and microplastics whereas toothed whales may ingest plastics if they look similar to prey items (Lusher et al., 2015). In conclusion, the foraging strategies of different species affect the interaction of an animal with plastics, and ingestion frequency may differ amongst species with special techniques or species of prey. Although indiscriminate omnivorous predators and filter feeders appear the most prone to plastic ingestion, there are many examples of selective feeders ingesting plastics. Scavenging individuals may also ingest plastic though the passive uptake of sediment (Murray \& Cowie, 2011). Increased feeding of biofouled versus clean plastic has also been shown for planktonic crustaceans (Vroom et al., in revision) and for blue mussels (Bråte et al., submitted).

Finally, secondary ingestion occurs when animals feed on prey which had previously ingested plastic debris and has been suggested for seabirds (van Franeker et al., 2011), fish (Perry et al., 2013), crustaceans (e.g. Murray \& Cowie 2011; Watts et al., 2014), and seals (Eriksson \& Burton, 2003). Perry et al. (2013) found a "ball" of nylon fishing line in little auk that was inside the stomach of a fish. Trophic transfer of microplastics has been demonstrated experimentally in several species ranging from 
zooplankton to larger invertebrates to fish (Setälä et al., 2014; Farrell \& Nelson, 2013; Batel et al., 2016).

Historically, there are more records of plastic ingestion for birds, turtles and mammals. Studies on plastic ingestion by fish and invertebrates are emerging with recent developments within the expanding field of microplastics, and the evolution of the topic since it was first suggested to affect organisms (Thompson et al., 2004).

Figure 3: Ingestion of plastics in different marine species

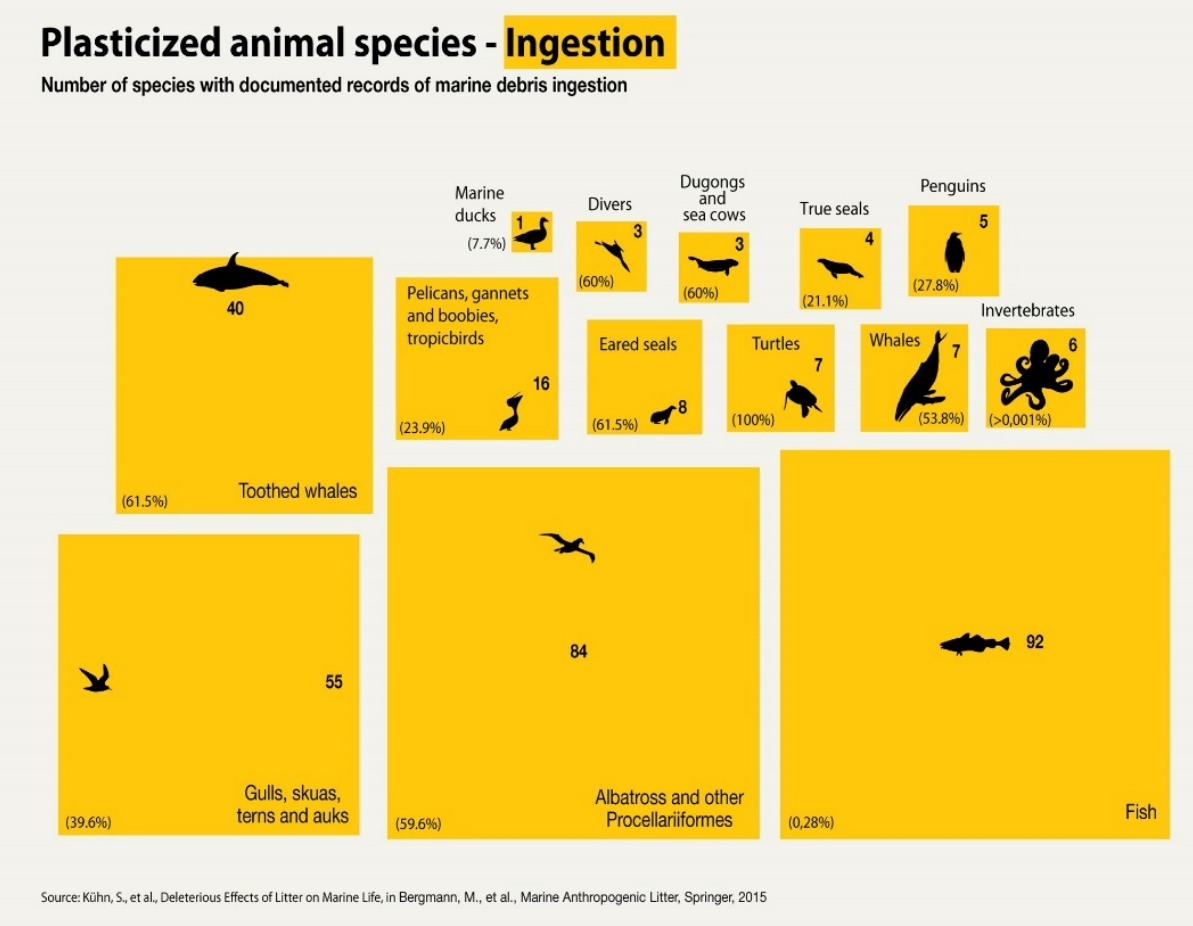

Source: Data originally from Kuhn et al. 2015. Adopted by GRID-Arendal (2016).

Many species of fish from the Pacific, Atlantic and Indian Ocean, and the Mediterranean Sea had individuals with microplastics in their digestive tracts. The mean concentrations of microplastics in digestive tracts are typically low, one to two items per individual (Lusher, 2015; GESAMP, 2016). A recent report by the FAO (in press) summarized that 12 out of the 25 most important species and genera that contribute to global marine fisheries had at least one individual which contained microplastics (Table 2.). 
Table 2: Presence of microplastics in the most important commercial species of fish. SD: Standard deviation

\begin{tabular}{|c|c|c|c|}
\hline Species & Common name & No of microplastics & Reference \\
\hline Clupea harengus & Atlantic herring & $\begin{array}{l}\text { Range } 0-4 \\
\text { / } \\
\text { Range o-3 }\end{array}$ & $\begin{array}{l}\text { Foekema et al., } 2013 \\
\text { Collard et al., } 2015 \\
\text { Rummel et al., 2016; }\end{array}$ \\
\hline Engraulis japonicus & Japanese anchovy & $2.3 \pm 2.5$ & Tanaka \& Takada, 2016 \\
\hline Gadus morhua & Atlantic cod & $\begin{array}{l}\text { Range o-2 } \\
\text { Range 0-4 } \\
\text { Range } 0-2\end{array}$ & $\begin{array}{l}\text { Foekema et al., } 2013 \\
\text { Bråte et al., } 2016 \\
\text { Liboiron et al., } 2016\end{array}$ \\
\hline Micromesistius poutassou & Blue whiting & Mean 2.14 & Lusher et al., 2013 \\
\hline Sardina pilchardus & European pilchard & $\begin{array}{l}\text { I } \\
\text { Mean } 1.78 \pm 0.7(S D) \\
\text { Mean } 2.75 \pm 1.57(S D)\end{array}$ & $\begin{array}{l}\text { Collard et al., } 2015 \\
\text { Avio et al., 2015a } \\
\text { Güven et al., } 2017\end{array}$ \\
\hline Scomberomorus cavalla & King mackerel & Range o-6 & Miranda et al., 2016 \\
\hline Scomber japonicus & Chub mackerel & $\begin{array}{l}\text { Mean } 0,57 \pm 1,04(S D) \\
\text { Mean } 10.25 \pm 5.86(S D)\end{array}$ & $\begin{array}{l}\text { Neves et al., } 2015 \\
\text { Güven et al., } 2017\end{array}$ \\
\hline Scomber scombrus & Atlantic mackerel & $\begin{array}{l}\text { Mean } 0.46 \pm 0.78(S D) \\
\text { Range } 0-3\end{array}$ & $\begin{array}{l}\text { Neves et al., } 2015 \\
\text { Rummel et al., } 2016\end{array}$ \\
\hline Decapterus macrosoma & Shortfin scad & Mean $2.5 \pm 6.3(S D)$ & Rochman et al., 2015 \\
\hline Decapterus muroadsi & Amberstripe scad & Mean $2.5 \pm 0.4(S D)$ & Ory et al., 2017 \\
\hline Sardinella longiceps & Indian oil sardine & Presence & Sulochanan et al., 2014 \\
\hline
\end{tabular}

Source: Adapted from FAO in press.

It is also evident that lower trophic level species ingest microplastics. Microplastics have been found in both farmed and wild blue mussels (Mathalon \& Hill, 2014; Van Cauwenberghe et al., 2015; Li et al., 2015). For all these studies, fibres were the most dominant microplastic particles observed. Wild-caught mussels were found with the lowest numbers of microplastics, less than 0.5 particles per gram in Europe, whereas the highest numbers were observed in Newfoundland, Canada, which were about 100fold higher than the levels measured in Europe (Mathalon \& Hill, 2014). Cultivated oysters have also been found to contain microplastics from the Atlantic Ocean (Van Cauwenberghe et al., 2014), and microplastics have also been identified in the gills, and digestive tracts of crustaceans from coastal waters of the North Sea and Irish Sea including the brown shrimp, (Crangon crangon) and the Norway lobster, (Nephrops norvegicus) (Devriese et al., 2015; Murray \& Cowie, 2011; Welden \& Cowie, 2016). Microplastics have also been found in the sediment dwelling marine lugworm, Arenicola marina, from the North Sea with up to 11 particles per gram (Van Cauwenberghe et al., 2015). 
Effects of ingestion on fish and invertebrates from laboratory studies

Plastics, in particular microplastics, have properties which make them susceptible for sorption of hydrophobic organic pollutants which are present in the environment (Gouin et al., 2011; Rochman, 2013). Common compound found in microplastics include DDT, PAHs and PCBs, and these are hydrophobic chemicals which have a long life in the environment as they are resistant to environmental degradation and may persist for several years and might transfer to marine biota (GESAMP, 2016). At this moment, several researchers suggest that this route for POP exposure to biota is minor when compared to other sources of environmental pollutants (e.g. Lohmann, 2017; Koelmans et al., 2016). Therefore, this aspect is not focused on in great deal within this report.

It appears that fish can cope with consuming non-digestible material, they are adapted and have evolved to egest undigested material including sand (Grigorakis et al., 2017). However, it has also been observed that nanosized plastic particles are found in the circulatory systems and translocated to the fish liver (Avio et al., 2015b). In addition, it has been found that such exposure to nanoparticles can change fish metabolism (Cedervall et al., 2012). Plastic exposure has also been found to change gene expression for example up-regulation of fatty acids and down regulation of amino acids (Lu et al., 2016) while also other impacts following microplastic exposure have been found, such as hepatic stress (Rochman et al., 2013).

Impacts from microplastic exposure of invertebrates in laboratory studies have also been found. Blue mussels ingesting microplastics at 3 and $10 \mu \mathrm{m}$, was found with the potential to translocate particles from the digestive tract to the circulatory system (Browne et al., 2008). von Moos et al. (2012) demonstrated that small plastic particles could accumulate in epithelial cells of the digestive system and this induced an inflammatory response. Furthermore, it has also been found impacts on oyster reproduction after microplastic exposure (Sussarellu et al., 2015). For lugworm, several studies have found effects on their feeding activity after microplastic exposure; exposure to polyvinylchloride (PVC) (Wright et al., 2013) or polystyrene (Besseling et al., 2013) that reduced their feeding activity (number of casts produced). This reduction in feeding activity was also found in another laboratory test looking at the biodegradable polylactic acid (PLA) as well as HDPE and PVC. In this exposure study, PVC was found to cause the strongest response of the three polymers (Green et al., 2016).

\subsubsection{Impact on society and economy}

Plastics can have societal and economic impacts. As an example, plastics can have aesthetic consequences such that visitors may be discouraged from frequenting unsightly locations where plastics litter the shorelines (GESAMP, 2016) and plastics can have direct and indirect effects on their physical and mental health (Wyles et al., 2016). With the ongoing research on physical risks associated with the potential of microplastics in foods for human consumption, there is a risk that consumers that perceive a risk may alter their perspectives on seafood. If microplastics currently represent a human health risk are unknown, but there are many uncertainties and this may lead to a shift of consumer habits away from seafood. There are also a series of 
impacts on activities from a range of economic sectors - notably fishing and aquaculture, tourism and recreation, and shipping. For example, impacts on fishing can include reduced income for fishers because of reduced fishing days or a reduction in catchable product following ghost fishing. Tourism and recreation may be affected if people are discouraged from visiting areas that are heavily impacted. Shipping may be affected by plastics, since it can be a navigational hazard through accidents, fouling and repair costs. Finally, there may be a loss of income reduced seafood consumption due to the "fear" of microplastic consumption (GESAMP, 2016). 



\title{
3. Methods for establishing the presence of plastic in biota
}

\begin{abstract}
There are many different methods used for establishing the presence of plastics in biota, and method development is still ongoing. Sampling considerations should include replicability, comparability, contamination control and consider environmental conditions when sampling. Methods of extraction include e.g. visual dissection of digestive tracts and through dissolving digestive tract contents with chemicals such as potassium hydroxide $(\mathrm{KOH})$. Once plastics have been extracted they can be assessed based on visible observations of their morphological characteristics, and using analytical techniques to determine the chemical characteristics of polymers.
\end{abstract}

In the following section, sampling considerations for monitoring biota are discussed, focussing primarily on microplastics. To obtain a comprehensive view of the presence of macro- and microplastics in the environment it is important to consider all parts of the marine environment, including surface water, water column, sea floor, benthic sediment and shorelines. There are many different methods available for sampling these matrixes, some attempt has been made to offer recommendations for sampling or standardized approaches. This section will not go into detail on the methods used to extract microplastics from sediment and water samples, since this is not within the scope of this report. There are however, numerous literature available on sampling plastics from the environment (e.g. Hanke et al., 2013; Hidalgo-Ruz et al., 2012; Nuelle et al., 2014; GESAMP, 2016). In short, once samples are collected they can be pretreated to reduce their volume by way of sieving, density separation or filtering. Once samples have been reduced, researchers usually identify microplastic presence (presence/absence, \% occurrence in samples, and amount) and follow with a validation step to visually accept particles based on characteristics, e.g. Lusher et al. (2014), or through analysis of their molecular structure, e.g. Löder \& Gerdts (2015).

\subsection{Sampling considerations}

There are several sampling factors that must be considered before commencing the identification of plastic in the environment (FAO in press). These are (i), replicability; (ii), comparability of methods with other studies; (iii) influence of environmental conditions; and (iv), contamination controls. Currently, many different methods are used to identify microplastics and concerns exist as to whether results are a true representation of microplastic contamination in the environment. For example, 
concerns include those relating to inter-study comparisons due to inconsistencies in methods and units reported, and the confounding patterns of spatial and temporal variability (e.g. Doyle et al., 2011; Goldstein et al., 2013). Variables, that influence sampling, need to be understood to aid in method standardisation or the development of best practice guidelines.

Sampling wild organisms provides researchers with the opportunity to understand the interactions of biota with plastics in the environment. However, issues arise when sampling organisms for microplastics due to their small size. Handling and processing steps could alter the presence of microplastics in individual specimens. For example, there may be loss of microplastics prior to animal preservation because of handling stress, physical movement, and the physiological and behavioural specificities of the sampled organism (Table 3, FAO in press). Furthermore, exposure to airborne contamination may falsely increase microplastic occurrence.

Table 3: Steps to minimise biases from handling and processing biota being assessed for plastic contamination

\begin{tabular}{|c|c|c|}
\hline Step & Issue & Steps to reduce bias \\
\hline Trawling & $\begin{array}{l}\text { Regurgitation in fish following expansion } \\
\text { of swim bladder when brought up from } \\
\text { depth }\end{array}$ & $\begin{array}{l}\text { Reduce the speed of capture to } \\
\text { avoid/minimise regurgitation. } \\
\text { If individuals have an empty stomach with } \\
\text { signs of recent emptying, organisms should } \\
\text { be discounted from analysis }\end{array}$ \\
\hline Capture in cod end & $\begin{array}{l}\text { Ingestion of microplastics which are also } \\
\text { retained in the cod-end of net (i.e. manta } \\
\text { net, } 250 \mu \mathrm{m} \text { ) }\end{array}$ & $\begin{array}{l}\text { Time spent in cod end should be as short as } \\
\text { possible }\end{array}$ \\
\hline Collection from fish farms & $\begin{array}{l}\text { Capture method cannot be controlled for } \\
\text { MP contamination }\end{array}$ & $\begin{array}{l}\text { Efforts should be made for researchers to } \\
\text { collect organisms themselves }\end{array}$ \\
\hline $\begin{array}{l}\text { Purchasing from } \\
\text { commercial fish markets }\end{array}$ & $\begin{array}{l}\text { Capture method is unknown and cannot } \\
\text { be controlled for MP contamination }\end{array}$ & $\begin{array}{l}\text { Researchers should obtain as much } \\
\text { information from vendors as possible }\end{array}$ \\
\hline $\begin{array}{l}\text { Stage of digestion } \\
\text { (gut evacuation time) }\end{array}$ & $\begin{array}{l}\text { Some animals might egest microplastic } \\
\text { debris prior to analysis }\end{array}$ & $\begin{array}{l}\text { Time between sample collection and } \\
\text { preservation of organisms must be as short } \\
\text { as possible }\end{array}$ \\
\hline Handling of individuals & $\begin{array}{l}\text { Handling stress or physical damage might } \\
\text { cause microplastic regurgitation }\end{array}$ & Minimise handling \\
\hline
\end{tabular}

\subsection{Extracting plastics from biota}

Usually birds, turtles, sharks and marine mammals are studied for macroplastic ingestion. Macroplastic items that have been ingested by biota are usually identified according to their appearance in digestive tracts following investigation of dead carcasses, regurgitation or faecal pellets. (Mrosovsky et al., 2009; van Franeker et al., 2011; Baulch \& Perry, 2014; Nelms et al., 2017) while extraction of microplastics ingested by biota can be achieved through numerous different methods. Once organisms have been collected, the target tissues need to be extracted. Methods for extracting microplastics from biotic material include dissection, depuration, 
homogenization and digestion of tissues with chemicals or enzymes (Lusher et al., 2017). Localization of microplastics can be determined by excising organs, such as the digestive tissues, liver, gills, or, edible tissues when the research question relates to risks of human consumption (e.g. Devriese et al., 2015). In most cases, research has focused primarily on the digestive tracts of individuals.

Microplastics present in dissected tissues can be isolated using saline washes, density flotation, visual inspection, or digestion (Lusher et al., 2017). Isolating microplastics present in biota or excised tissues can be challenging if the presence of plastic particles is masked by biological material such as algae, microbial biofilms and detritus. Researchers have developed protocols to digest organic matter leaving recalcitrant materials. Protocols include acids (e.g. nitric acid, formic acid, hydrochloric acid, alkalis (e.g. potassium hydroxide), oxidizing agents (e.g. hydrogen peroxide) and enzymes (Proteinase K) (e.g. GESAMP, 2016). Potassium hydroxide (KOH) seems to be the most widely used and perhaps most appropriate strategy since this treatment does not alter the structure of the polymers present in the matrix, is economically cost efficient, utilizes easily accessible chemicals and requires a simple sampling procedure (Foekema et al., 2013; Dehaut et al., 2016; Kühn et al., 2016). After digestion, the remaining solution can be filtered to retain resistant materials. Microplastics can be visualized directly, transferred to slides, or extracted from the filtered material. After cleaning the matrix (e.g. stomach content) with alkaline solution, saturated salt solutions can separate plastic particles from organic material based on their density. Saturated salt solutions including $\mathrm{NaCl}$ (aq), $\mathrm{Nal}$ (aq) and $\mathrm{ZnCl}_{2}$ (aq) allow the separation of less dense particles from inorganic matter such as sand, chitin and bone that will previously not have dissolved. $\mathrm{NaCl}$ is inexpensive and non-hazardous, but it may lead to an underestimation of more dense particles $(>1.2 \mathrm{~g} \mathrm{~cm}-3)$. The high density of $\mathrm{NaCl}(\mathrm{aq})$ and $\mathrm{Nal}(\mathrm{aq})$ allows the floating of high-density plastics (FAO in press).

\subsection{Methods for identifying plastics extracted from biota samples}

This section focuses on confirming the identity of extracted plastics and the following steps can be used on microplastics if their identity is uncertain.

Once target tissues have been prepared, the quantity and types of microplastics in the sample need to be ascertained. Visual identification, based on morphological characteristics, is an essential step when going through samples. However, it is recommended that visual identification is supported by subsequent polymer analysis using advanced analytical techniques to determine the chemical characteristics of polymers (Lusher et al., 2017). Plastics can be classified by their morphological characteristics including size, shape and colour. Size is typically based on the longest dimension of a particle and particles can be sorted into size groups. There are five main categories for shape: beads, fibres, fragments, foams and films (Table 4). Visual identification of microplastics, especially in the smaller size range, should be supported by secondary analyses to confirm the identity of polymeric material. 
Table 4: Classifications used on microplastic shapes

\section{Shape classification Other terms used}

Fragments Irregular shaped particles, crystals, fluff, powder, granules, shavings, flakes, films

Fibres Filaments, microfibres, strands, threads

Beads Grains, spherical microbeads, microspheres

Foams Polystyrene, Expanded Polystyrene

Pellets Resin Pellets, nurdles, pre-production pellets, nibs

Source: Adapted from Lusher et al. 2017.

Analytical techniques used to identify polymers are for example: non-destructive vibrational techniques such as Fourier Transformed Infra-Red spectrometry (FTIR); Attenuated Total Reflectance (ATR), Raman spectrometry; automated scanning coupled with microspectrometry, and destructive techniques such as Pyrolysis-Gas Chromatography combined with Mass Spectroscopy (Pyr-GC-MS), high temperature gel-permeation chromatography (HT-GPC) with IR detection; SEM-EDS and thermosextraction; and desorption coupled with GC/MS. Raman and FTIR spectroscopies are preferred as they are non-destructive, since we want information of morphology and size of the plastic particles. For more information on these techniques see e.g. Lenz et al. (2015), Wesch et al. (2016) and Löder and Gerdts (2015).

There has also been suggested low-cost techniques that involves the use of polarized light microscopes to observe birefringent properties of polymers, or the use of Nile Red to colour plastic polymers (Maes et al., 2017; Shim et al., 2017). These lowcost techniques might have a potential to solve problems that exist with more traditional techniques; such as expensive and sensitive laboratory equipment, mismatches/errors with visual identification (which also requires extensive use of manpower), and due to chemical identification of polymers due to problems with weathered, bio-fouled and natural polymers. 


\section{Plastics in the Nordic marine environment}

Abstract: Plastics pollute the Nordic Marine Environment despite the comparatively good waste handling systems of Norway, Sweden, Denmark, Finland, and Iceland. For the Nordic region, plastics are found on beaches, at the sea surface, in the water column, at and in sediment and even in sea ice. Most available literature of plastic in fish and invertebrates from the Nordic biota are from reports. Specifically, there are nine studies which have looked at 14 different fish species, most of which were conducted in the Baltic Sea and the North Sea and blue mussels are the most studied invertebrate. Comparability between and within studies from the Nordic environment and other regions, are difficult as there are 1) a limited number of studies, 2) limited number of studies on the same species from different location and, 3) different methods used.

\subsection{Plastic pollution in the Nordic marine environment}

Although Scandinavian countries use comparatively good waste handling systems compared to other parts of the world (Plasticseurope, 2016), plastics and marine litter are polluting the Nordic marine environment (Figure 4).

To understand the scale of plastic pollution in the marine environment, it is necessary to monitor the sources and presence of litter items over adequate temporal and spatial scales. As an example, OSPAR, The Convention for the Protection of the Marine Environment of the North East Atlantic, has been monitoring 50 indicator beaches with standardised protocols since 1998. For more information, refer to the OSPAR Beach Litter Database (OSPAR 2010 - http://www.mcsuk.org/ospar/). Available information on Plastic pollution in the Nordic region has been summarized to date in the TemaNord report "Marine Litter in Nordic waters" (Strand et al., 2015). Although there are important knowledge gaps on the distribution of both macro- and certainly for microplastics in these large and varied regions. Specific recommendations for waste management and waste monitoring in the Nordic environment have been proposed by OSPAR, Nordic Council, the European union (EU) and the Baltic Marine Environment Protection Commission (HELCOM). HELCOM and OSPAR are in the process of recommending specific indicators for the Baltic Sea and North-East Atlantic, respectively. Furthermore, many NGOs from Nordic countries are working with marine pollution; for example, there are about 30 NGOs in Norway that are involved in activities such as including beach cleaning and public awareness.

For example, NGO's and charities such as "Hold Norge Rent", "Håll Sverige Rent", "Hold Danmark Rent", "Pidä Saaristo Siistinä ry" (Finland), "Ringrás" (Faroe Islands), 
"Landvernd" (Iceland) and "Håll Sverige Rent" carry out regular beach cleanings and data are compiled into online databases, that are used for annual reports on the litter status in these respective countries. On the 6th of May 2017, all five Nordic countries launched a joint initiative for the first time, the "Nordisk Strandrydde Dag" (Nordic Coastal Cleanup 2017). Other on-going projects trying to reduce the input of plastic waste and monitor its distribution in the Nordic marine environment is "Fishing for Litter" (in Sweden, Denmark and Faroe Island) (Strand et al., 2015). In Norway for example, "Fishing for litter" is a trial project lead by SALT on behalf of the Norwegian Environment Agency. This campaign currently operates in four Norwegian harbours: Egersund, Karmøy, Ålesund and Tromsø with 32 vessels joining. In 2016 they collected 48 tonnes of waste with $37 \mathrm{~kg}$ of this being classified as fishing gear (Johnsen et al., 2017; personal comm. Runar Mathisen - Norwegian Environment Agency).

\section{Figure 4: Plastic pollution of the Nordic environment. Shorelines in Troms Fylke, Tromsø, Norway}

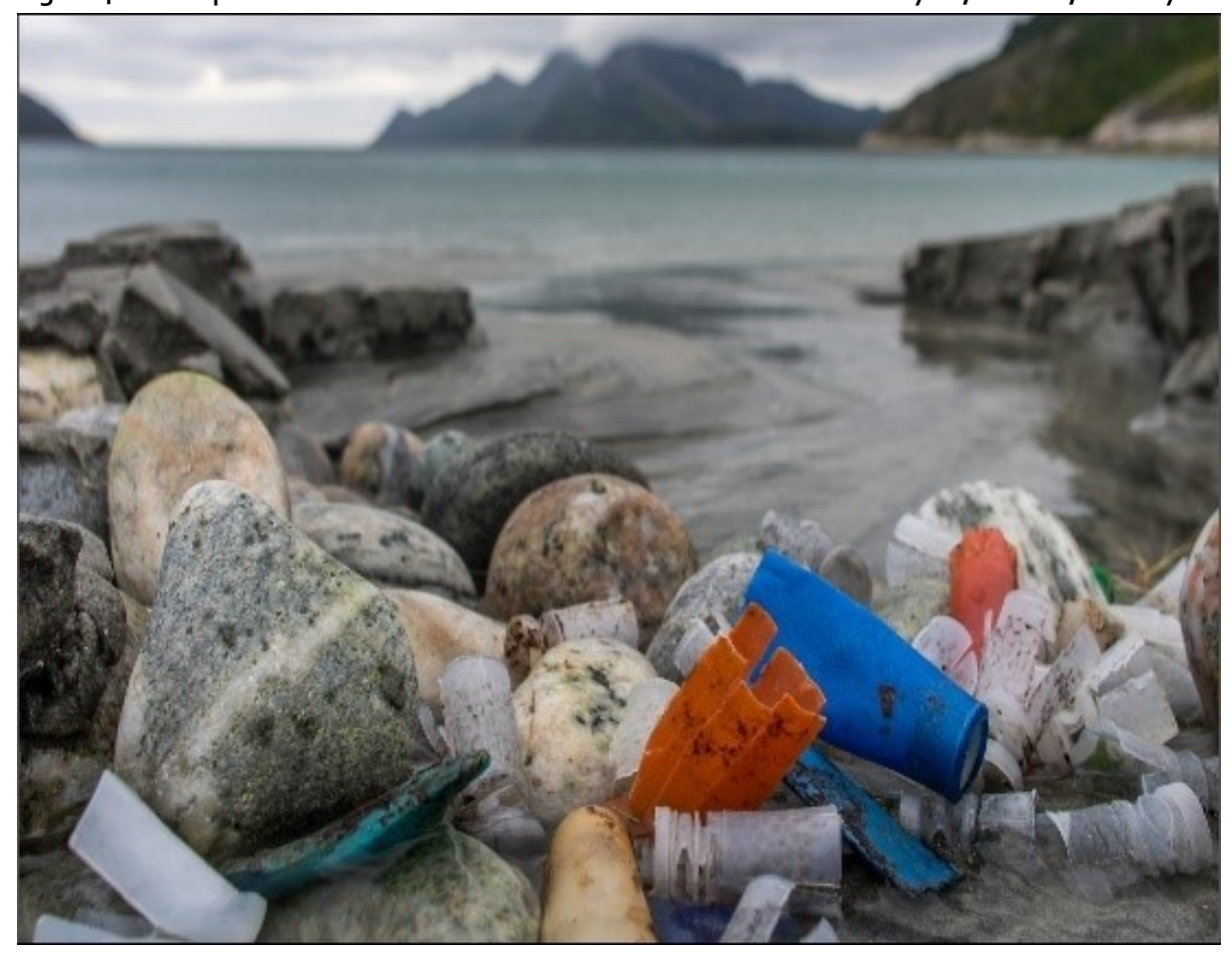

Source: Photo: Bo Eide

\subsubsection{Sources}

Plastic items are the dominant contributor to litter in all parts of the Nordic marine environment. Plastics in the Nordic waters can originate from local, regional, and global sources because of long-range transport on ocean currents as well as localized input. Most of the marine litter consist of plastics, for example a survey in the Barents Sea in 2014 found that plastics were the most dominant marine litter in pelagic and bottom trawls (Eriksen, 2014) Currents can impact the distribution of plastics since it can be transported everywhere by time, regardless of origin (van Sebille et al., 2012). It is suspected that 
buoyant plastics are transported into the Nordic environment on the ocean currents from further afield, such as through transport from the North Atlantic or the North Atlantic Drift (van Sebille et al., 2012; Amy L Lusher et al., 2015; Cózar et al., 2017).

The contribution of plastic items to marine litter appears to increase from the Baltic Sea $(62 \%)$ to Skagerrak $(76 \%)$ and the eastern North Sea $(71 \%)$ and furthermore towards the North Atlantic (88\%) and the Arctic (97\%), indicating that plastic items may be transported over long distances (Strand et al., 2015). The west coast of Sweden, Bohuskusten, was found to be a hot-spot for plastic pollution (Svärd, 2013), which may be due to litter coming from the North Sea and driven by currents and wind to Skagerrak (UNEP, 2005). Studies from an internationally coordinated ichthyoplankton survey targeting herring larvae, have also done pilot studies on the occurrence and distribution of marine litter in the water column of the North Sea (ICES, 2017). In the purely Danish study during 2014-2016 an area in the central North Sea between Denmark and the UK was covered (Huwer, pers. comm.), whereas in 2017 all countries involved in the herring larvae survey participated, allowing for the coverage of the entire North Sea area. Preliminary results indicate that most of the marine litter items in the water column were made of plastic, and most litter is found along the Danish west coast and in Skagerrak (ICES 2017; Huwer, pers. comm.)

Three comprehensive reports have assessed the main sources of microplastics into the Danish environment (Lassen et al., 2015), Norwegian environment (Sundt et al., 2014) and Swedish environment (Magnusson et al., 2016). For the Danish environment, secondary microplastics are estimated to be the biggest contributor of microplastics to the environment, 5,000 to 12,200 tonnes per year, while primary microplastics account for 460-1,670 tonnes per year (Lassen et al., 2015). For the Norwegian environment however, the annual input of primary microplastics were estimated to be $\sim 8,000$ tonnes (Sundt et al., 2014). The largest source of secondary microplastics to the environment to the Norwegian environment was attributed to abrasion of studded car tires and road markings, so-called road dust, with $\sim 5,000$ tonnes estimated yearly input. The same report lists microplastics input from rubber granulates on artificial turfs, produced from used car tires as a form of recycling, as a major source. For the Swedish environment 250-2,000 tons was estimated as the annual input of primary microplastics from WWTPs, while approximately 13,000 tons of microplastics are estimated to be released from car tyres every year. For the artificial turfs, there was an estimated loss of 2,300-3,900 tons per year, but the report also highlighted that there is no information on how much is entering the aquatic environment. Car tire microplastics were found in fresh water sediment in the two main rivers in Oslo (Norway); Alnaelva and Akerelva (two masterthesis; Bottolfsen 2016 and Buenaventura, 2017, in press) (Figure 5) and preliminary findings of granulates in streams close to football fields in Oslo (NIVA-unpublished). It is important to note that these numbers are estimates and empirical data are needed to confirm this. Furthermore, Magnusson \& Norén (2011) identified large numbers of "black particles" which were a heterogeneous group of anthropogenic particles smaller than $50 \mu \mathrm{m}$. The identity of these particles where not analytically confirmed by e.g. FTIR, but the authors speculate that the particles come from road wear and combustion processes. 
Figure 5: Example of car tire particle found in sediment from a Norwegian freshwater river

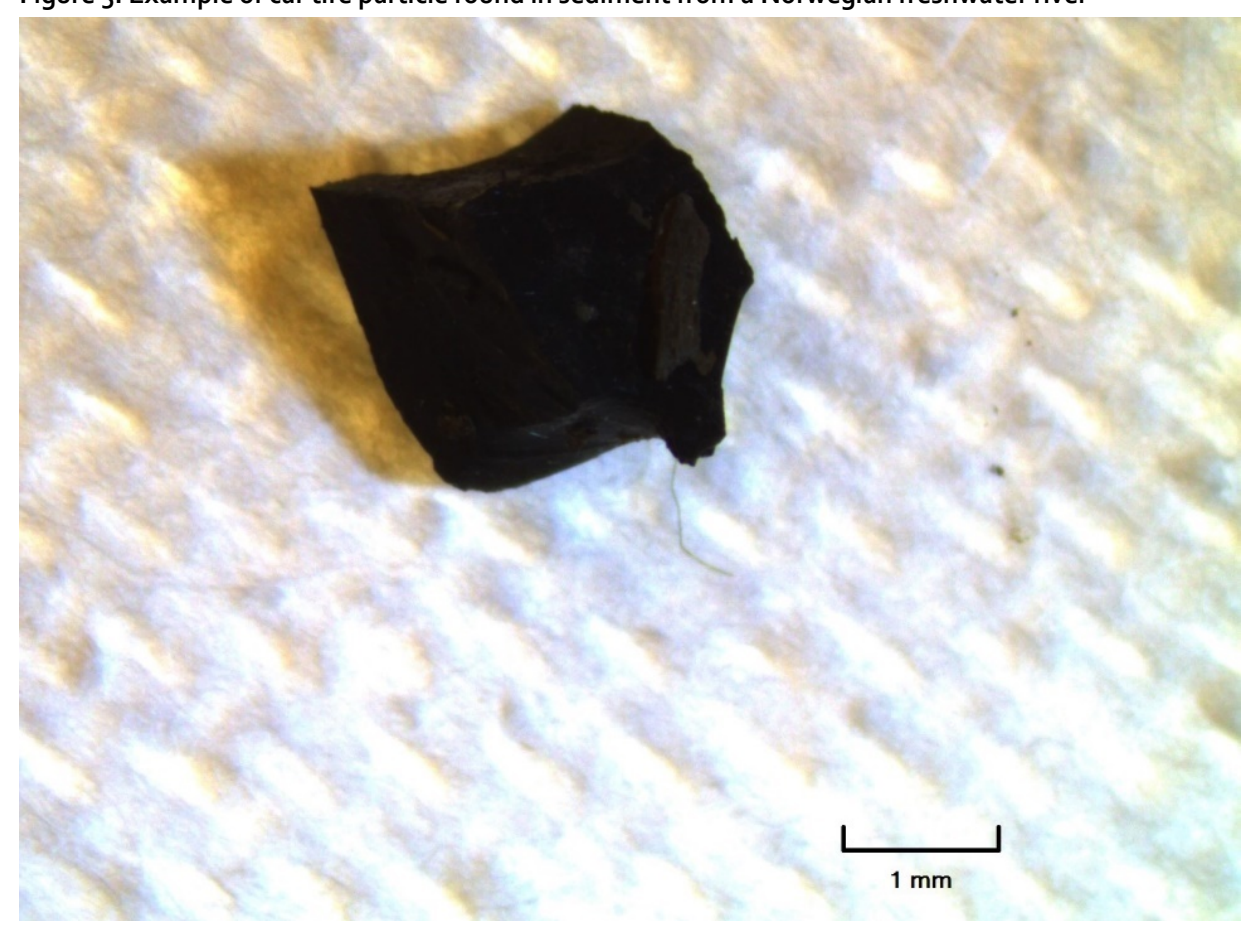

Source: Photo NIVA.

The theoretical estimates of the contribution of WWTP to microplastics in the Nordic environment discussed above, are not the same for the different regions. Empirical data are available for Nordic WWTPs. For example, a recent report based on empirical data from Denmark found large variations in the level of microplastic from ten different WWTP, ranging from 0.2 to $30 \mathrm{mg}$ per litre. Following the treatment, approximately $3 \%$ remained in the effluent making the wastewater treatment process very efficient (Vollertsen \& Aviaja, 2017). Another study on three different WWTPs in Sweden found between 7,000-30,000 microplastic particles $(>300 \mu \mathrm{m})$ and 60,000-80,000 particles $(>20 \mu \mathrm{m})$ per cubic meter in inlet water (Magnusson \& Wahlberg, 2014). However, after the cleaning process, 70 to $100 \%$, of the microplastics were contained inside the WWTPs. Despite this, the effluent going into the receiving aquatic environments still contained between 1-100 microplastics $(>300 \mu \mathrm{m}$ ) and 1,000-10,000 microplastics ( $>20$ $\mu \mathrm{m})$ per cubic meter. Magnusson \& Norén (2014) found that $99 \%$ of microplastics $>300$ $\mu \mathrm{m}$ were retained in the sludge of a small WWTP in Sweden found that $99 \%$ of the particles larger than $300 \mu \mathrm{m}$. Due to the efficient cleaning of WWTP it appears that it is not a major source of microplastics into the Nordic environment, however this is depending on the cleaning of the effluent discharged from the WWTPs. A study Magnusson et al. (2016) on Swedish, Finnish and Icelandic WWTPs found that more than $99.7 \%$ of the microlitter were retained within the treatment plant for the Swedish and the Finnish plants. However, for the Icelandic plants, only a limited number of microlitter particles were retained within the cleaning facility. Both the Swedish and 
Finnish WWTPs had chemical and biological treatment of the waste, while the Icelandic plants only had mechanical waste water treatment.

This shows the importance of having sophisticated WWTPs to reduce the microplastic load coming from treatment plants. The study also found microplastics in sediment and biota near the WWTPs, suggesting that this could be a possible source for microplastic pollution to our Nordic marine environment (Magnusson et al., 2016). Even though most of the Nordic countries have sophisticated WWTP facilities, it can be times when plants are not working adequately or undergoing maintenance such as overflow after heavy rainfall, there may be a higher level of input of microplastics to the recipient water course. Physical characteristics of microplastics can also change the amount particles being retained in the sludge retention; for example, it has been found that fragments and beads are retained to a higher extent than fibres (Michielssen et al., 2016). As microplastics are retained in sludge, it is important to consider sludge as a potential source of microplastics, when it is used as fertilizer in agriculture (Nizzetto et al., 2016).

The highest numbers of beached litter items are generally found along the coastlines of Skagerrak (items per area) followed by the eastern North Sea (Strand et al., 2015) which suggest that this region is an important sink for plastics released in the southern North Sea. Local anthropogenic activity is also causing plastic pollution, for example, urban beaches around the Baltic Sea contained more litter (237 items per 100 $\mathrm{m}$ ) than rural beaches (76 items per $100 \mathrm{~m}$ ) (MARLIN, 2013).

Hydrodynamic modelling data suggested that a gyre of plastic debris may also be present in the Barents Sea (van Sebille et al., 2012). The first empirical observations of microplastics on the Barents see were reported between Tromsø and Svalbard (70$78^{\circ} \mathrm{N}$ ) during an exploratory expedition in 2014 (Lusher et al., 2015). It was also hypothesised that as the sea ice retreats and shipping and fishing activity increase there may be greater input of marine pollution in to the Arctic, although base-line data on contamination from ocean transport and local input are required (Lusher et al., 2015). Furthermore, a recent study by Cózar based on empirical data has now shown that the occurrences of an accumulation zone in the Arctic is indeed the case, with high microplastic concentrations being found in the northern and eastern areas of the Greenland and Barents Seas (Cózar et al., 2017). Sea ice can be both a source and sink for entrained plastics in the Arctic, such that it accumulates floating microplastics when it freezes which are then released when it melts (Obbard et al., 2014; Lusher et al., 2015). An ice core collected from the Fram Strait, published in 2017, contained high concentrations of microplastics (mean concentrations of $2 \times 106$ particles $\mathrm{m}-3$ in pack ice and $6 \times 105$ particles $\mathrm{m}-3$ ) in land-locked ice, with PE being the most abundant polymer (Bergmann et al., 2017).

Marine litter also pollutes the seafloor of the Nordic marine environment, much of it being plastic (Figure 6). Insufficient quantitative information is available regarding plastic pollution on the Nordic seafloor, but from quantifying litter from the seafloor $(2,500 \mathrm{~m})$ at the eastern Fram Strait, Bergmann \& Klages (2012) found an increasing amount of litter over time. Plastic items increased from 3,635 to 7,710 items $\mathrm{km}^{2}$ between 2002 and 2011, and these levels are comparable to levels reported from a canyon near the Portuguese capital Lisboan. 
Figure 6: Sea floor from the Oslofjord, clearly polluted with waste

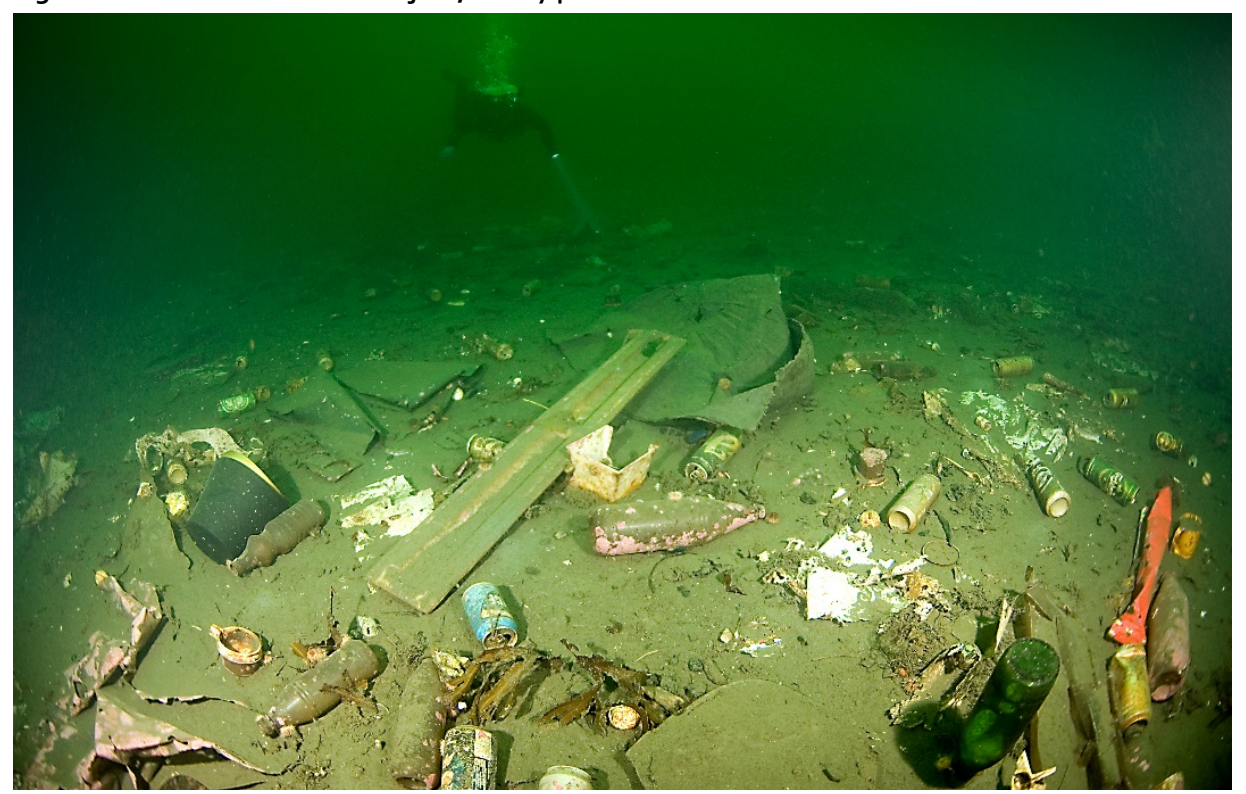

Source: Photo: Fredrik Myhre.

\subsubsection{Effects on Nordic biota}

Plastics are impacting Nordic biota in many ways. Animals are entangled (Figure 7), birds use items for nesting materials and biota ingest plastics. For example, a study on a kittiwake colony in northwest Denmark found that $39 \%$ of the 466 nests analysed in 1992 contained plastic, whereas $57 \%$ out of 311 nests contained plastic in 2005 (Hartwig et al., 2007). This behaviour of using plastics as nesting material is related to the problem of entanglement, as many birds are getting strangled by the plastic in their own nests. This indicates the extent of plastic pollution in surrounding waters, as gannets collect almost all their nest material at sea. 


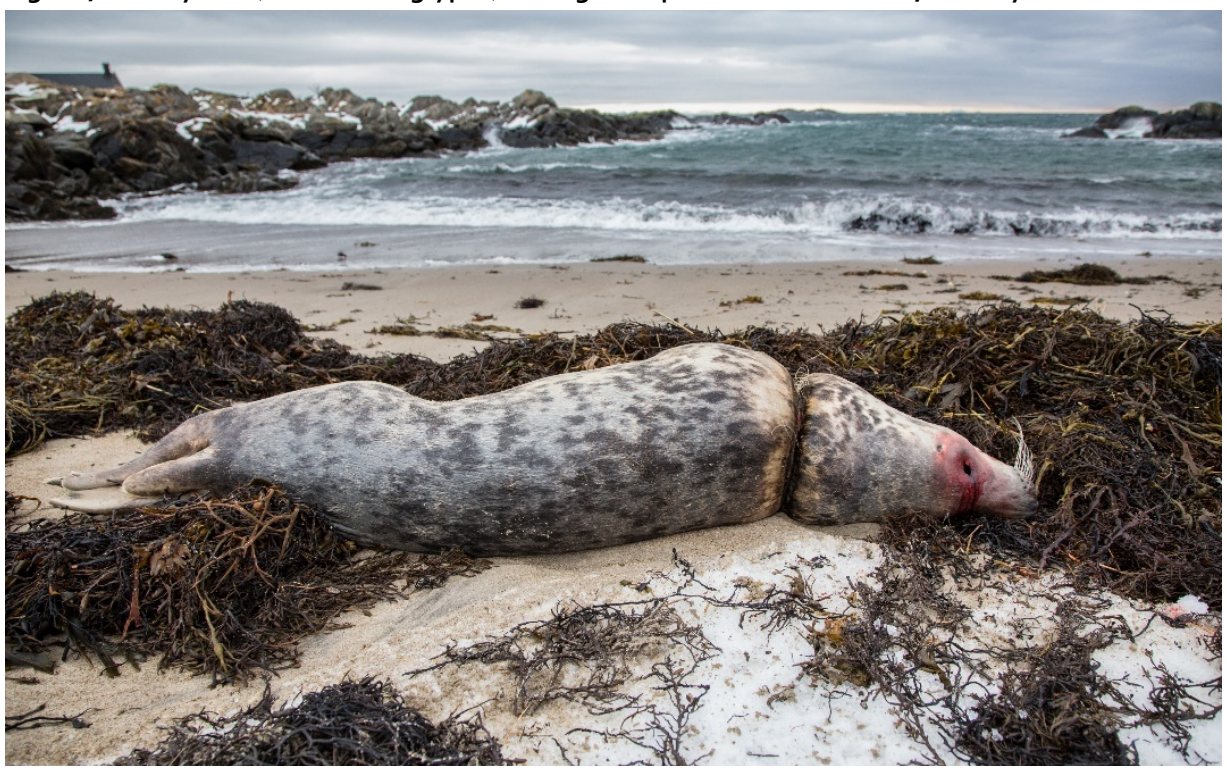

Source: Photo: Eric Fokke.

\subsection{Plastic ingestion in Nordic Marine biota}

\subsubsection{Birds}

Birds from the Nordic area are well-known to ingest plastics (Figure 8). On a global scale, sea birds have been found with an increasing amount of plastics being ingested from the 1960s, however it might found that the levels have stabilized over time (Ryan et al., 2009). Most data on plastic ingestion within the Nordic area comes from seabirds, based on decade-long monitoring efforts with northern fulmars (Fulmarus glacialis) (van Franeker et al., 1985, 2011). Many monitoring schemes were initially devised to target visible plastic items and most studies do not include data of microplastics, i.e. items smaller than $1 \mathrm{~mm}$. Certain seabirds have been found to ingest large quantities of plastics. Recently, Savoca et al. (2016) proposed that procellariforms were ingesting large amounts of plastics because they are attracted to the chemical compound dimethyl sulphide (DMS), which is associated with marine plastics. This is possibly due to DMS also being a natural compound released by marine algae, producing a scent that can be picked up by marine organisms including seabirds and may represent a biological cue for the presence of food. Furthermore, Provencher et al. (2010) suggested that birds feeding on crustaceans and cephalopods had more plastics than piscivorous seabirds, possibly because they are more likely to confuse their prey with plastics.

It has been suggested a clear North-south dimension of \% of Northern fulmars exceeding the OSPAR system of Ecological Quality Objectives (EcoOOs) limit sat to $0.1 \mathrm{~g}$ ingested plastic per bird; $86 \%$ of the birds in the English Channel, $60 \%$ in the North 
Sea, $41 \%$ in the Faroe Island, $28 \%$ in Iceland and $23 \%$ in Svalbard (Trevail et al., 2015). Other monitoring studies from the Nordic environment have also investigated temporal and spatial trends in plastic ingestion by seabirds. For example, data from the North Sea and Skagerrak (2002-2011), show that 95\% of the examined fulmars had ingested plastics (van Franeker et al., 2011). No significant decrease in amount of plastic in fulmar stomachs has been found over the last decade, which suggests that plastic levels in the environment might have stabilised (OSPAR 2015). Other trends are present also; a change in the types of plastic ingested. In the 1980s, half of the plastic found in the fulmars were from industrial origin and half from user plastics, whereas at present user plastics outnumber industrial plastics by a factor of 10 (Van Franeker et al., 2015).

Figure 8: The Northern gannet (Morus bassanus) with plastics, from Lofoten (Mosken)

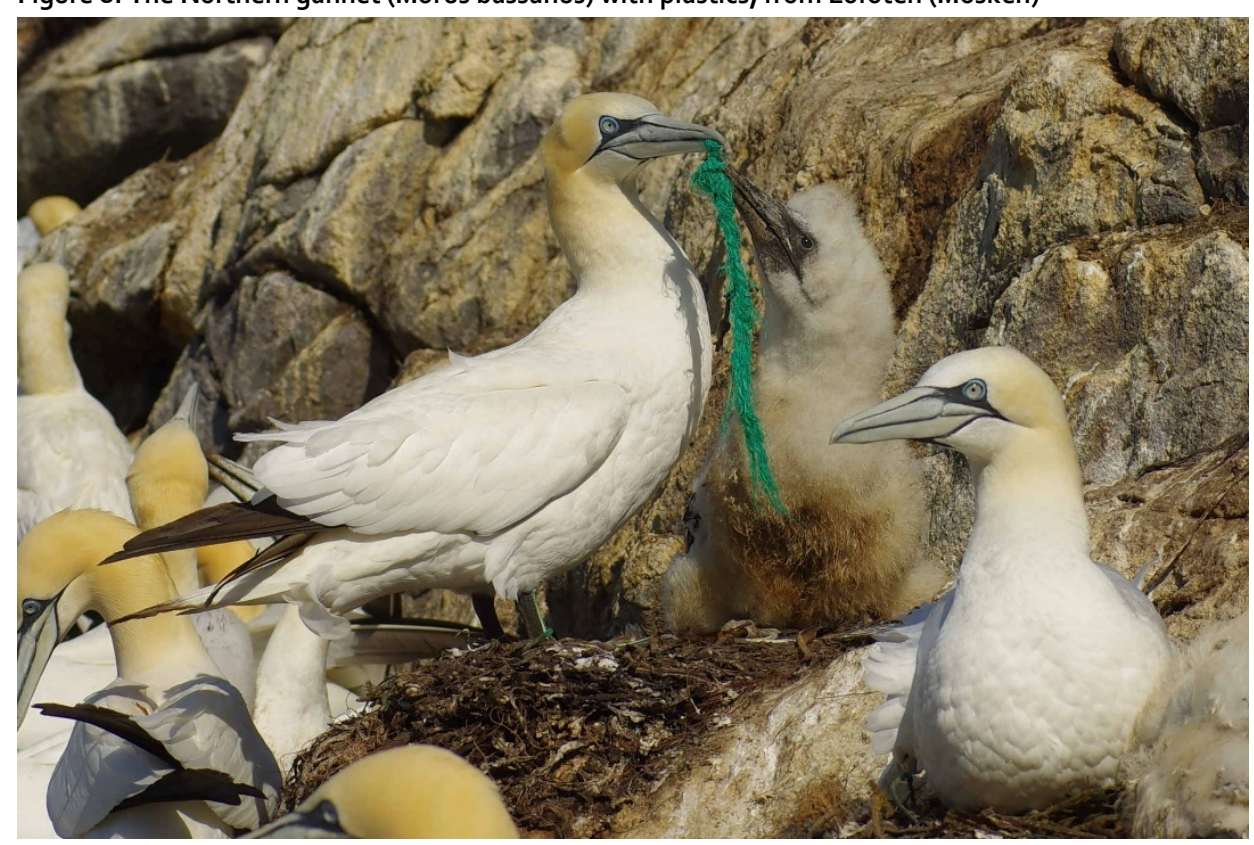

Source: Photo: Bo Eide

\subsubsection{Marine mammals and sharks}

For mammals and sharks from the Nordic environment, most of the data available are qualitative from studies that did not focus on plastic ingestion. However, data is still of interest since it highlights the fact that mammals and sharks from the Nordic marine environment are ingesting plastic. For example, plastic items were found in the stomach content of Greenland sharks (Somniosus microcephalus) in waters around Greenland (Nielsen et al., 2014) as well as Svalbard (Leclerc et al., 2012). Plastics were also found in a sperm whale (Physeter microcephalus) caught off the coast of Iceland (Lambertsen \& Kohn, 1987) and quantitatively 6 out of 82 fin whales (Balaenoptera physalus) sampled in waters around Iceland in summer 1985 contained "synthetics" (Sadove \& Morreale, 1989). A Cuvier's beaked whale (Ziphius cavirostris) which stranded near Bergen, West Norway, contained about 35 plastic bags, food packaging and larger plastic sheets (Terje Lislevand 
pers. comm.), which gained significant public interest. Also, a White-beaked dolphin (Lagenorhynchus albirostris) found stranded outside of Hvaler in the Kattegat, had a "ball" of entangled plastic in the stomach (NIVA, Figure 9).

Figure 9: Plastics found in stranded White-beaked dolphin from Hvaler, Norway (Kattegat). Pencil to show size of plastic "ball"

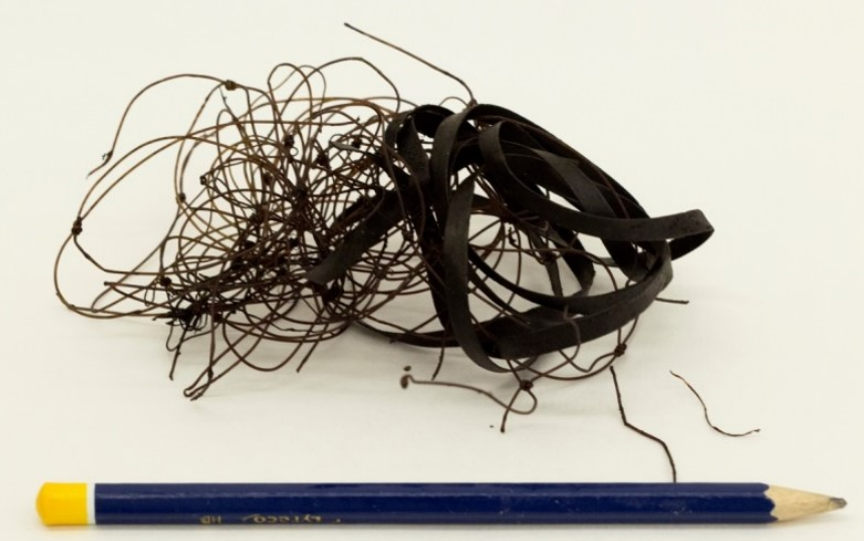

Source: NIVA.

\subsubsection{Fish and invertebrates}

From the literature reviewed in this report, 16 studies have investigated plastic ingestion in Nordic marine fish and invertebrates, Table 5 and Table 6 respectively. These data include to our knowledge, all available information, both peer-reviewed, non-peer reviewed reports, and bachelor and master theses. 
Table 5: Data collected for fish from the Nordic environment. MP per individuals: the range or mean of plastic ingested (if given) for the different fish species

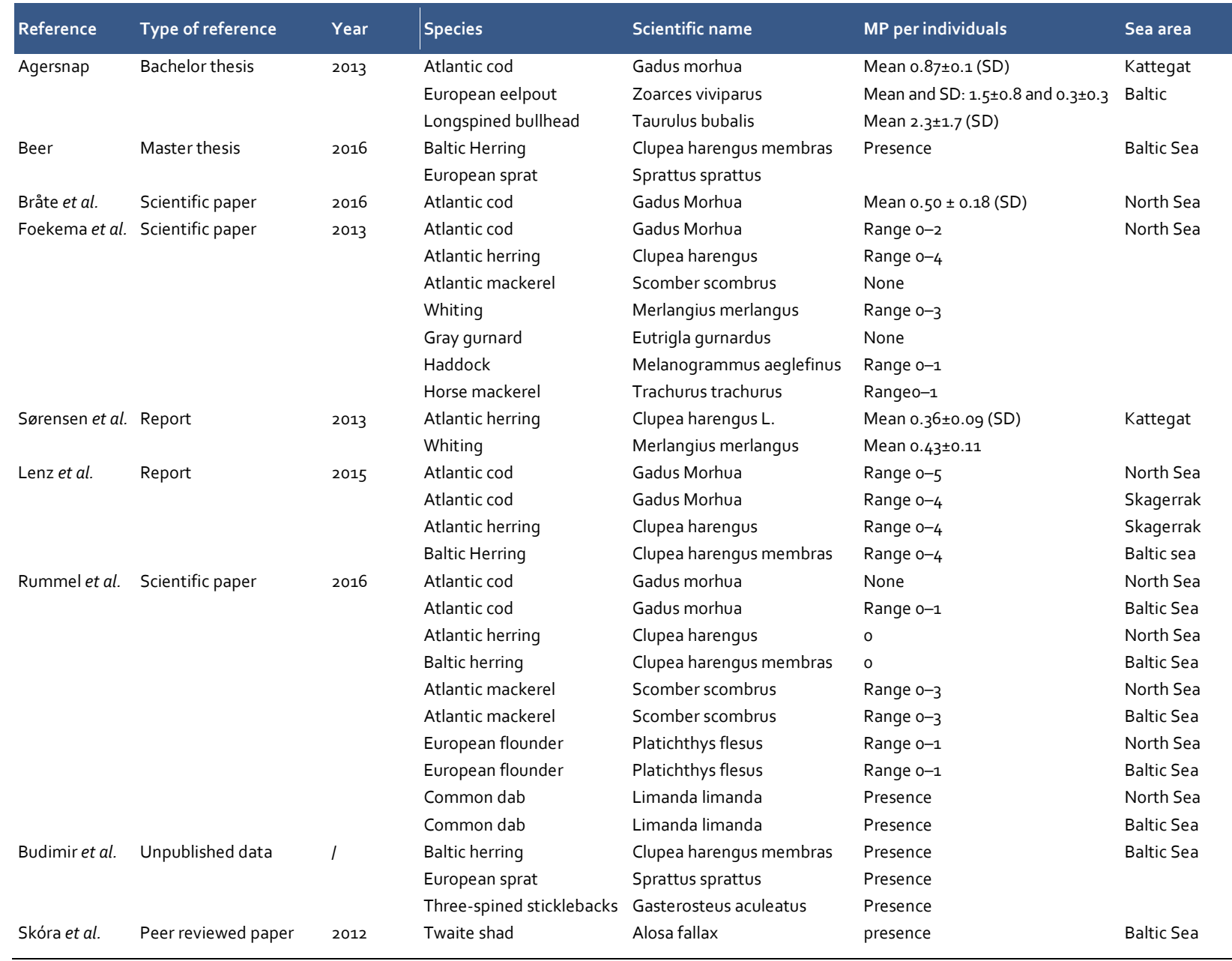


Table 6: Data collected for invertebrates from the Nordic environment.

\begin{tabular}{|c|c|c|c|c|c|}
\hline Reference & Type of reference & Year & Species & Scientific name & Sea area \\
\hline Agersnap & Bachelor thesis & 2013 & Blue mussel & Mytilus edulis & $\begin{array}{l}\text { Baltic sea } \\
\text { (Svanemøllen Strand) } \\
\text { Baltic sea (Kalvebod) }\end{array}$ \\
\hline Haave & $\begin{array}{l}\text { MICRO } 2016 \text { conference } \\
\text { abstract }\end{array}$ & 2016 & $\begin{array}{l}\text { Polychaeta } \\
\text { (Lugworm*) }\end{array}$ & $\begin{array}{l}\text { Arenicola } \\
\text { marina }\end{array}$ & $\begin{array}{l}\text { North Sea* } \\
\text { (Byfjorden Bergen) }\end{array}$ \\
\hline Gustafsson & Bachelor thesis & 2016 & Blue mussel & Mytilus edulis & Kattegat \\
\hline Sundet & Report & 2015 & $\begin{array}{l}\text { Blue mussel } \\
\text { Iceland Cockle }\end{array}$ & $\begin{array}{l}\text { Mytilus edulis } \\
\text { Clinocardium } \\
\text { ciliatum }\end{array}$ & $\begin{array}{l}\text { Greenland Sea } \\
\text { (Svalbard coast) }\end{array}$ \\
\hline Sundet & Report & 2014 & Snow-crab & $\begin{array}{l}\text { Eriocheir } \\
\text { sinensis }\end{array}$ & Near Varangerhalvøya \\
\hline Vandermeersch & Scientific paper & 2015 & $\begin{array}{l}\text { Blue mussel } \\
\text { (for human } \\
\text { consumption) }\end{array}$ & Mytilus edulis & Limfjorden \\
\hline $\begin{array}{l}\text { Wójcik- } \\
\text { Fudalewska }\end{array}$ & Scientific paper & 2016 & $\begin{array}{l}\text { Chinese mitten } \\
\text { crab }\end{array}$ & $\begin{array}{l}\text { Eriocheir } \\
\text { sinensis }\end{array}$ & Baltic Sea \\
\hline
\end{tabular}

Note: * Did also find anthropogenic fibers in Malacocerus fuliginosus, Chaetozone jubata, Pectinaria belgica, Terribellides stroemii, Pista cristata and Pectinaria auricoma.

Most studies have been conducted on fish, and less for invertebrates covering bivalves, crustaceans, and marine worms (Figure 10). For fish, 5,241 individual fish were examined within 9 different studies, while for bivalves 205 individuals have been examined within 6 different studies. For bivalves, all studies except from one was on blue mussels.

Figure 10: Studies on plastic ingestion in biota of the Nordic marine environment. Number of studies and individuals in parentheses The number of individuals per study were not available for all studies, therefore the numbers presented are underestimates

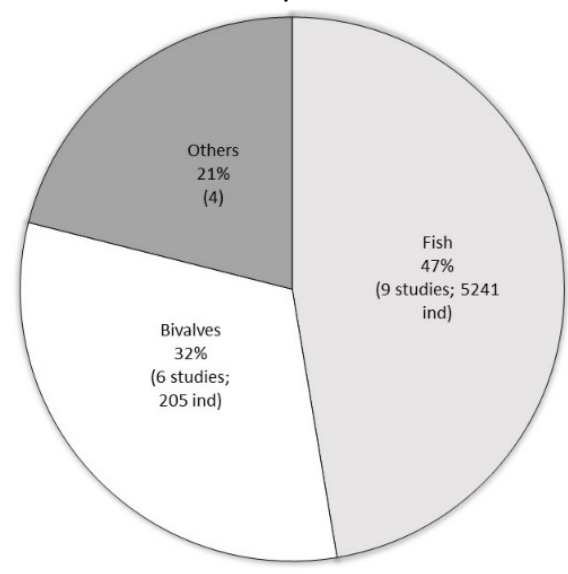


There are only two peer-reviewed studies of plastic ingestion by invertebrates from the Nordic environment. The number of peer-reviewed publications are expected to increase in the future, as there are several on-going projects investigating microplastics occurrence in a range of species. For example, blue mussels, shrimps, herring, mackerel, flounder, sculpin and cod are being investigated in Danish coastal waters and Greenland (Strand, pers. communication) and there are ongoing studies of blue mussels in the Norwegian environment (Bråte, ongoing).

Fish

Fourteen different species of fish have been studied in the Nordic environment. Most of the studies have been conducted in the Baltic Sea and the North Sea and the number of study locations per species is highly varied. A total of eight studies have investigated plastics in fish from the Nordic environment and the most studied species are herring and cod (Figure 11). The proportion of individual fish with plastics in the gastrointestinal tract (GIT) with more than one location studied for a specific species, is presented in Figure 12. From this boxplot, the variation in the proportion of individuals found to contain plastics is high, and there does not seem to be any apparent trends in the different species. However, it is important to note that the number of data sets is small.

Figure 11: Fish species studied for microplastic ingestion in the Nordic marine environment. Left: Based on number of individuals (in parentheses). Right: Based on number of locations (in parentheses)
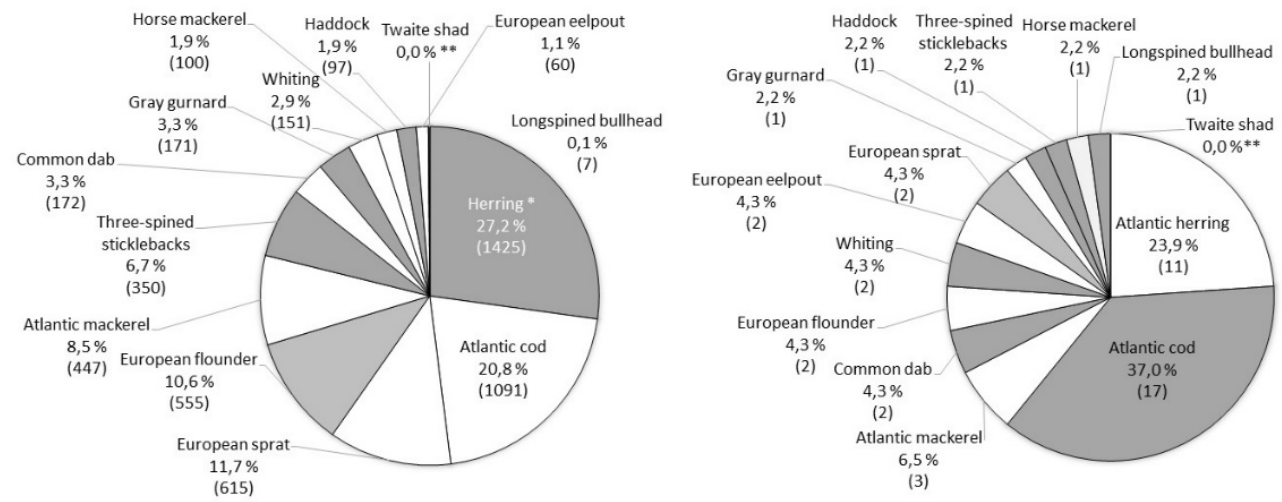

Note: *: Both Atlantic and Baltic Herring combined.

**: unknown number of individuals. 
Figure 12: Boxplot showing the median, maximum \%, and the lowest \% of microplastic present in fish stomachs given from each sample location (for one study). All studies on plastic ingestion in fish from the Nordic marine environment were included, with two or more sample locations. $\mathrm{N}$ equals numbers of study locations, either from reports or scientific papers*

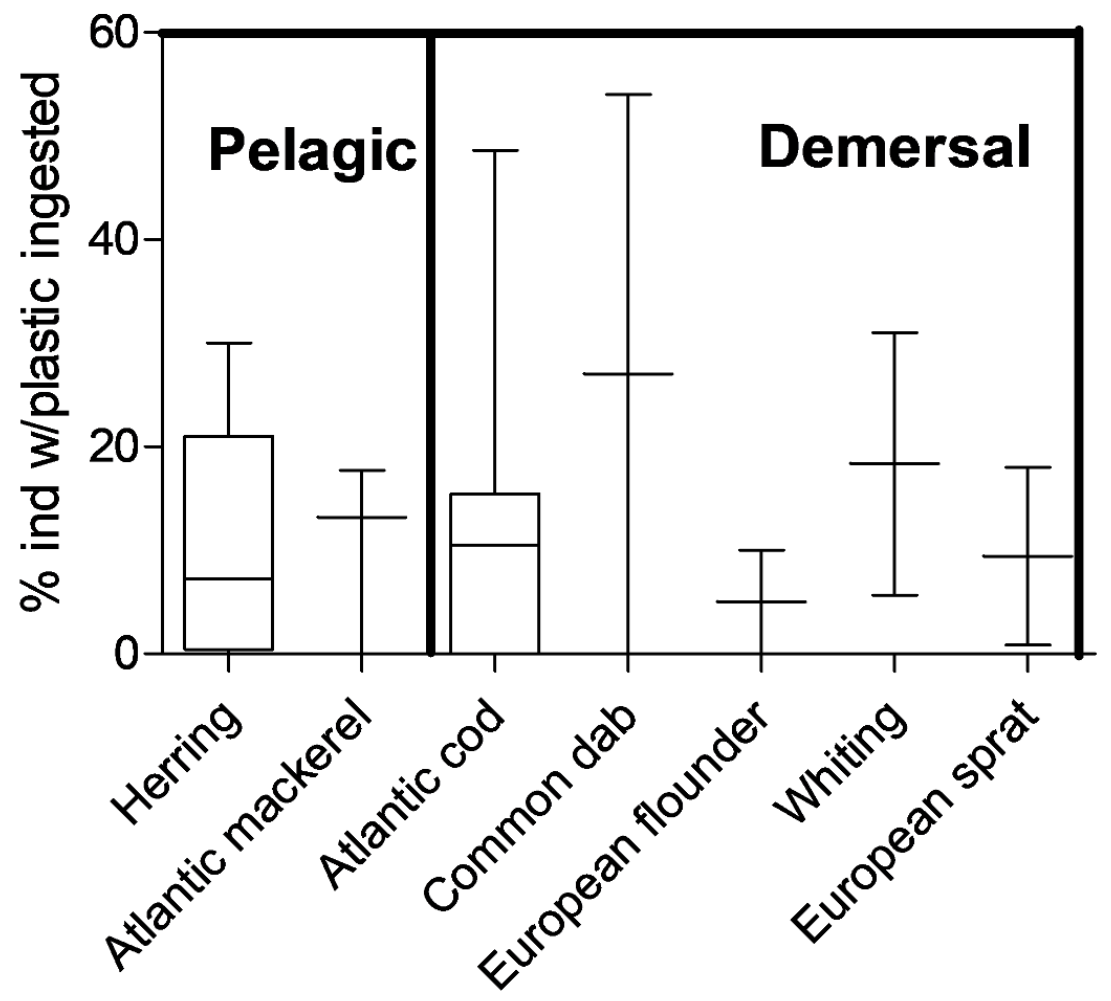

Note: For herring: combined both Atlantic and Baltic Herring.

Herring is the most studied fish species in the Nordic marine environment with 1425 individuals. The highest number of microplastic particles reported in an individual herring was 4 particles (Foekema et al., 2013; Lenz et al., 2016). The average number of microplastics reported for herring from Kattegat was reported as $0.36 \pm 0.096$ (Sørensen et al., 2013). Percentage ingestion of microplastics by herring ranged from $0 \%$ to $30 \%$ (Figure 12 and Figure 13 ).

Cod are the second most studied species in the Nordic marine environment $(1,091$ individuals) and samples of Atlantic cod were collected in coastal locations in the Norwegian Sea, Baltic Sea and North Sea, and from offshore locations in the North Sea and Baltic Sea (Figure 14). The highest percentage of ingestion in cod was reported in individuals from the offshore North Sea $(49 \%$, Lenz et al., 2015) followed by those from a coastal Norwegian harbour (27\%, Bråte et al., 2016) and the offshore Baltic Sea, coastal Baltic Sea and coastal North Sea $(26 \%, 16 \%$ and $14 \%$ respectively, Lenz et al., 2015). In other studies, $13 \%$ of individuals from the North Sea contained plastics ranging from o-2 particles per individual (Foekoema et al., 2013). The lowest recorded values were from an extensive study in the North Sea and Baltic Sea with only 1 Baltic Sea individual ( $1.4 \%$ of total) containing rubber in its stomach, and finally no individuals 
from a study in the North Sea had ingested plastics (Rummel et al., 2016). Number of ingested particles ranged from $0-4$. In one Norwegian study, an average of $0.5 \pm 0.18$ per individual was reported in Bergen Harbour, Norway (Bråte et al., 2016). Microplastics were also reported in cod from the Baltic Sea and the average ingestion from pooled data was $0.87 \pm 0.1$ particles per individual.

Other pelagic fish have also been investigated for plastics from the Nordic environment (Figure 15). Mackerel have been studied from three locations in the Nordic marine environment; $30.8 \%$ of individuals from the Baltic Sea and $13.2 \%$ of individuals from the coastal North Sea were found to contain microplastics (Rummel et al., 2016). No plastics were found in mackerel from the offshore North Sea ( $n=566$, Foekoema et al., 2013) and a single horse mackerel from the North Sea contained one microplastic particle ( $n=100$, Foekoema et al., 2013). Twaite shad from the Baltic contained microplastics although no values relating to ingestion were reported (Skóra et al., 2012). In European sprat from the Baltic Sea 18\% was been found to contain microplastics (Beer, 2016), also another study found microplastics in European sprat and three-spine sticklebacks, but this data is currently unpublished (Budimir et al., pers. communication).

Other demersal fish from the Nordic environment have also been investigated for plastics (Figure 16), and highest percentage ingestion was reported for dab from the coastal North Sea, $54 \%(n=75)$, although no individuals $(n=98)$ were found to ingest plastics in the Baltic Sea (Rummel et al., 2016). Microplastics were also reported for $31 \%$ of whiting from Kattegat ( $n=46$, Sørensen et al., 2013), $6.2 \%$ of haddock $(n=97)$, a single whiting (1\%) and a single flounder (10\%) from the North Sea, although no plastics were found in gurnards or flounders from the same locations (Foekoema et al., 2013; Rummel et al., 2015). Another species investigated for microplastics include eelpout and longspinned bullhead from the Baltic (Agersnap, 2013).

As evidenced from the previous discussion on fish ingestion from the Nordic marine environment, the data presented from both coastal and offshore locations have been studied in varying degrees, and includes a range of species from pelagic and demersal habitats. In addition to this data, some information on plastic ingestion can also be derived from studies that are not explicitly targeted on detecting plastic and other marine litter in biota, but do register ingestion of such items as a "side-product". This is particularly the case when analysing stomach content for feeding ecology of different species. For example, the DAPSTOM database held by CEFAS (Pinnegar, 2014), which is a large database on fish stomach content analyses containing more than 225,000 records from over 250,000 individual fish predator stomachs, lists many species which have ingested litter of the categories "Plastic rubbish", "Plastic strings" as well as "Rubbish". The database can be searched online (https://www.cefas.co.uk/cefas-datahub/fish-stomach-records/) for either "Prey of specified predators" or "Predators of specified prey", and accompanying data about predator size, sampling date and a rough indication of the sampling area can be downloaded. The species that were found to have ingested "Plastic rubbish" are cod (Gadus morhua), saithe (Pollachius virens), whiting (Merlangius merlangus), grey gurnard (Eutrigla gurnardus), lesser spotted dogfish (Scyliorhinus canicula) and blue shark (Prionace glauca). Cod, saithe and blue shark had also ingested "Plastic strings". While the sampling locations are not specified 
in detail, the database includes records of cod, saithe, whiting and grey gurnard from the North Sea area and for cod also from Spitzbergen.

Furthermore, plastic items were occasionally observed during a large-scale investigation of stomach contents of Baltic cod conducted to improve the understanding of species interactions, natural mortality and multi-species fish stock models (Huwer et al., 2014). Out of the almost 20,000 Baltic cod stomachs analysed, 27 were found to contain plastic, giving a total of $1.35 \%$ of the fish containing plastics.

Figure 13: Overview of studies on occurrence of microplastics in Atlantic and Baltic Herring in Nordic marine areas (codes on top are corresponding to codes in table $\mathrm{A} 1$ ). The locations are not accurate in many of the cases, since it is not easy to know exactly where the fish was caught

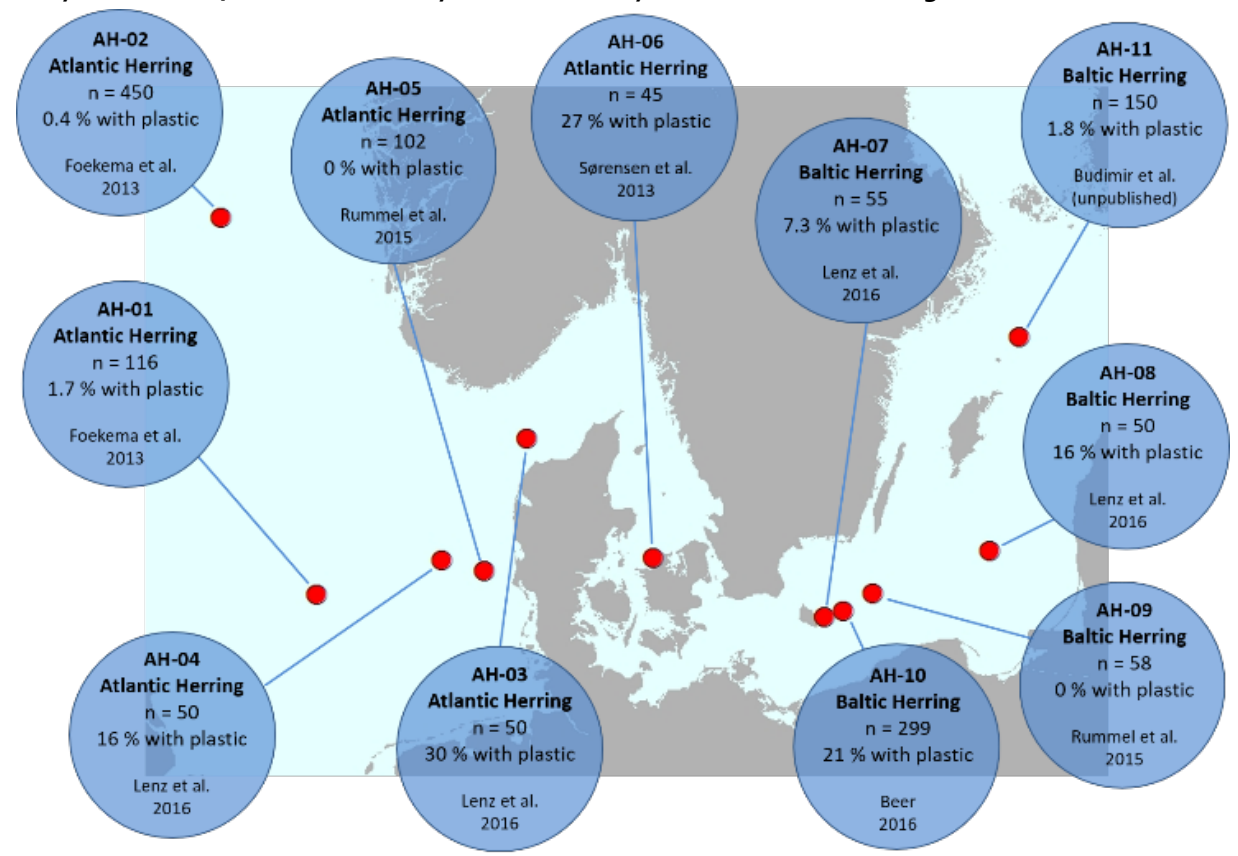


Figure 14: Overview of studies on occurrence of microplastics in Atlantic Cod (Gadus morhua) in Nordic marine areas (codes on top are corresponding to codes in table $\mathbf{A} 1$ ). The locations are not accurate in many of the cases, since it is not easy to know exactly where the fish was caught

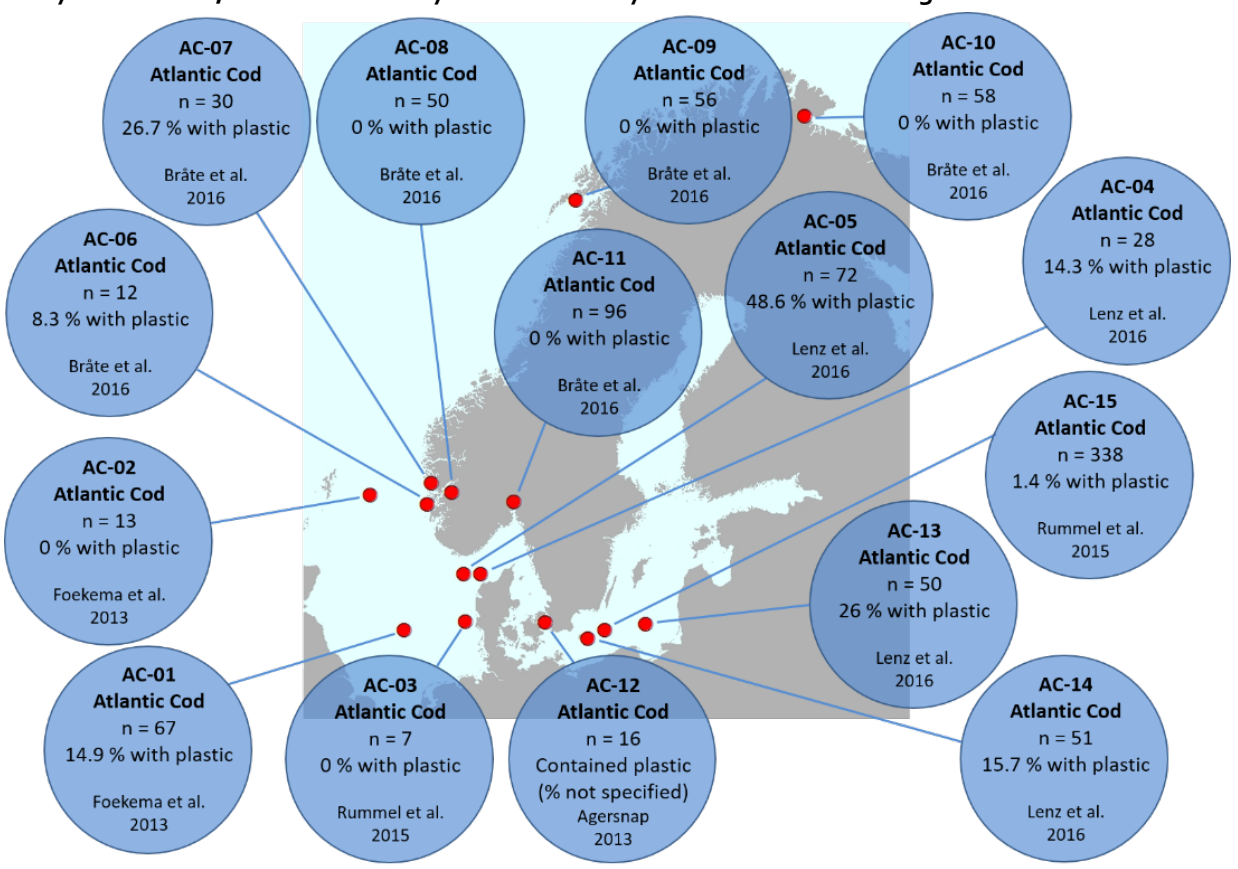

Figure 15: Overview of studies on occurrence in other pelagic fish than Herring in Nordic marine areas (codes on top are corresponding to codes in table 13). The locations are not accurate in many of the cases, since it is not easy to know exactly where the fish was caught

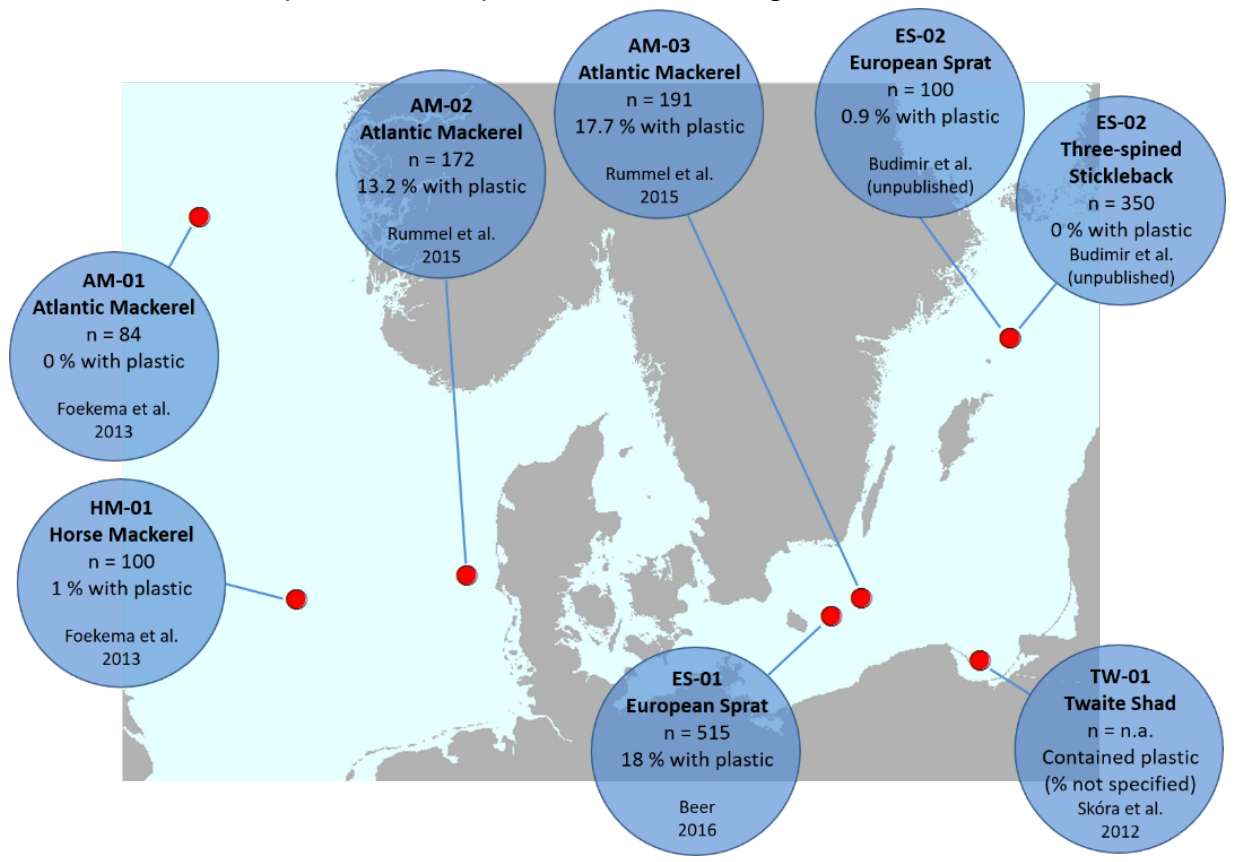


Figure 16: Overview of studies on occurrence in other demersal fish than Atlantic cod in Nordic marine areas (codes on top are corresponding to codes in table 13). The locations are not accurate in many of the cases, since it is not easy to know exactly where the fish was caught

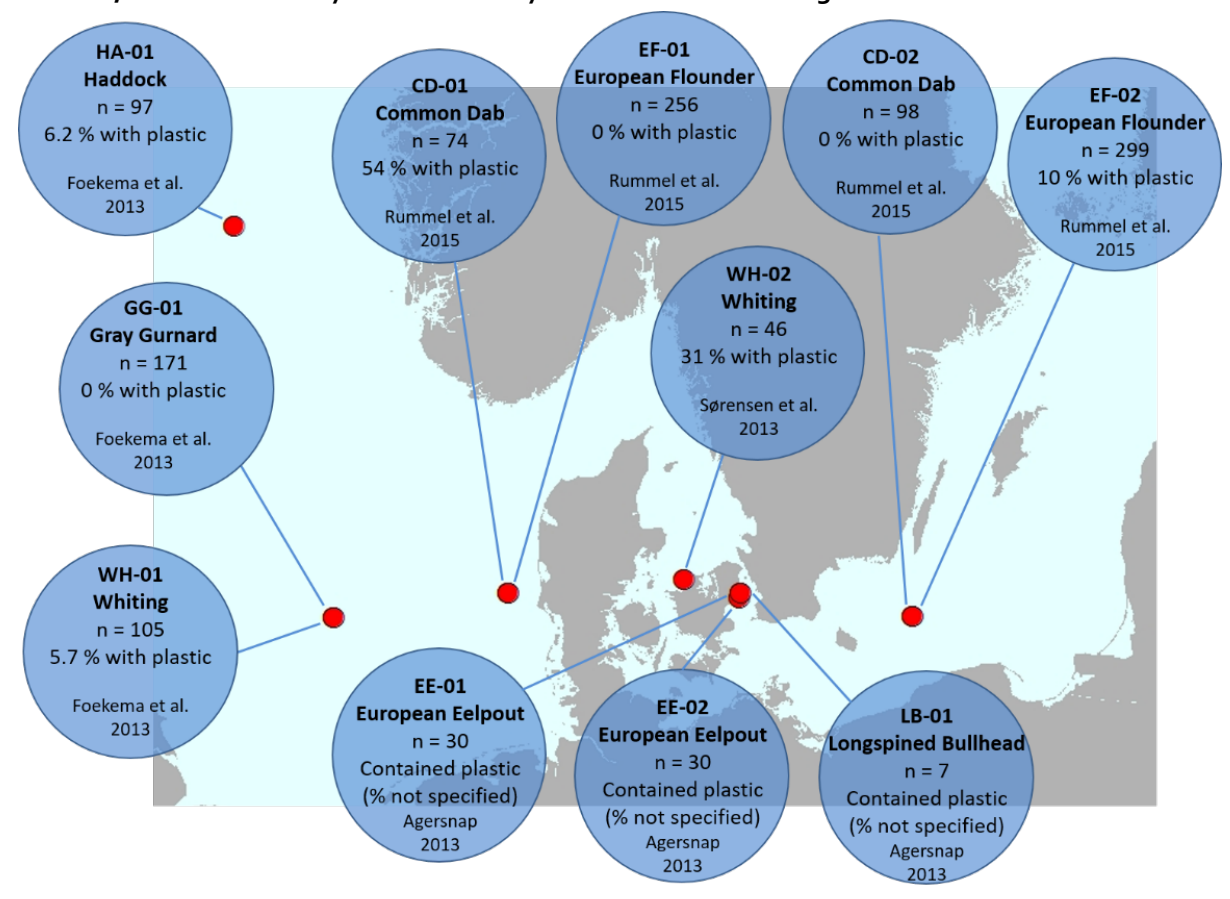

Invertebrates

As discussed previously there are very few studies on the presence of microplastics in invertebrates and the studies are dominated by research on bivalves, in particular, blue mussels (Figure 17). Due to the limited number of studies it is hard to say much of the status of microplastic ingestion in invertebrates from the Nordic marine environment. However, based on the available studies, microplastics appear to be ingested. Blue mussels from the west coast of Sweden and Svalbard contained primarily microplastic fibres (Gustafsson, 2016; Sundet et al., 2015) and blue mussels from locations near Copenhagen, Denmark, contained on average 1.2-2.5 particles per individual, corresponding to $0.6-1.5$ microplastic particles per gram wet weight (Agersnap, 2013). There are limited studies on benthic dwelling and deposit feeding invertebrates from the Nordic marine environment. Nine species of marine worms have been investigated in coastal North Sea waters, and fibres were found to be synthetic and cellulose by FTIRATR and Raman Spectroscopy were found, with Arenicola marina containing most fibres with a mean of 5.0 ( \pm 2.7 SD) particles (no of individuals=7) (Haave et al., 2016). Furthermore, synthetic fibres were found in the faeces of brittle stars and polychaetes from the sediments around Gullmarsfjorden, Sweden (Johansson, 2011). Plastics have also been found in Snow crabs (Chionoecetes opilio) from the Barents Sea (Sundet, 2014). 
Figure 17: Overview of studies on occurrence in shell fish, marine worms and crabs in Nordic marine areas (codes on top are corresponding to codes in the appendix

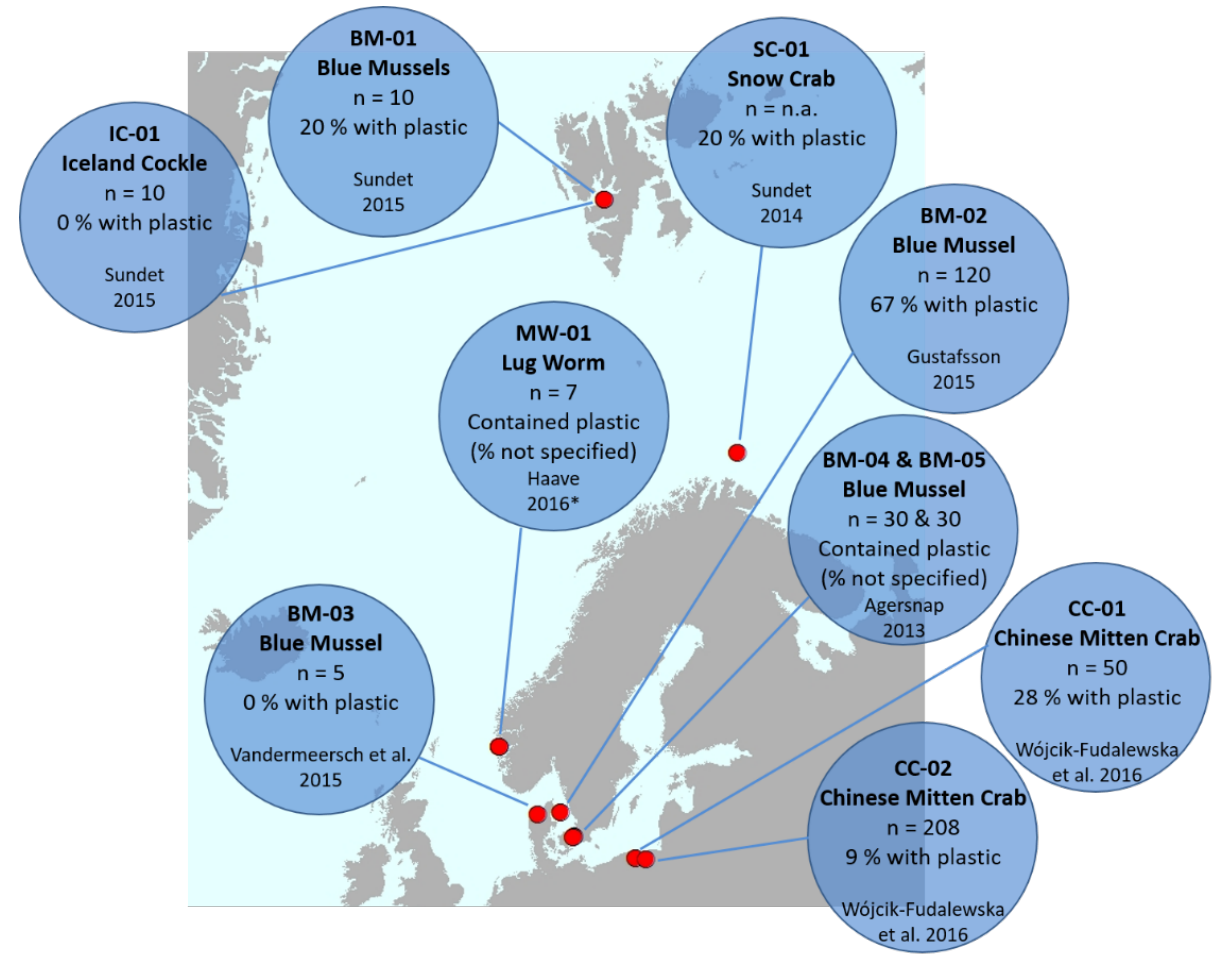

Note: * Did also find anthropogenic fibres in Malacocerus fuliginosus, Chaetozone jubata, Pectinaria belgica, Terribellides stroemii, Pista cristata and Pectinaria auricoma.

\subsubsection{Type of plastics found in Nordic marine biota}

In a study by Rummel et al. (2016) from the North Sea and the Baltic Sea, $40 \%$ of the ingested polymer in fish was polyethylene. Comparatively, the most common microplastic polymers found in the water column of the Baltic Sea in 2017 were PP $(53 \%)$ and PE (24\%). Therefore, it is not surprising that pelagic fish ingest the polymers that are found in the water column. This also corresponds to the density of the polymers (shown earlier in Table 1) as clean PP and PE float in seawater. Furthermore, cod from the North Sea ingested primarily polyester particles (Figure 18 and Figure 19) which might correspond to primarily demersal feeding in the lower depths, and polyester due to its density, which is higher than that of sea water will sink. Other polymers that have been found ingested by biota from the Nordic environment included polyamide (PA) that can come from ropes typically used for fishing. When trying to connect the type of microplastic polymer found in the environment with the source of pollution, it is important to note that it is challenging to make a clear link. For example, PE can both be a primary microplastic being released from WWTPs effluent (Carr et al., 2016) or as the secondary break-down product of a plastic product (e.g. plastic bag). Sometimes though, it is possible to infer potential sources based on polymer type and physical 
characteristic, for example when finding polyester fibres, it is likely that these fibres originated from clothing. For the Chinese mitten crab, it was suggested that it was likely that the ball of plastics they found in the crab was from fishing gears by studying pictures of the plastics found (Wójcik-Fudalewska et al., 2016).

Figure 18: Data from Bråte et al. 2016. Polymers found in Atlantic cod from the Norwegian coast, all from Bergen city harbour with exception of polypropylene (PP). No. of plastic items equals 16. Polyester: Polycyclohexylenedimethylene terephthalate, PVC: Polyvinyl chloride, PS: Polystyrene, Teflon: Polytetrafluoroethylene, Nylon, PE: polyethylene, SAN: Styrene acrylonitrile resin, PBMA: poly(n-butyl) methacrylate

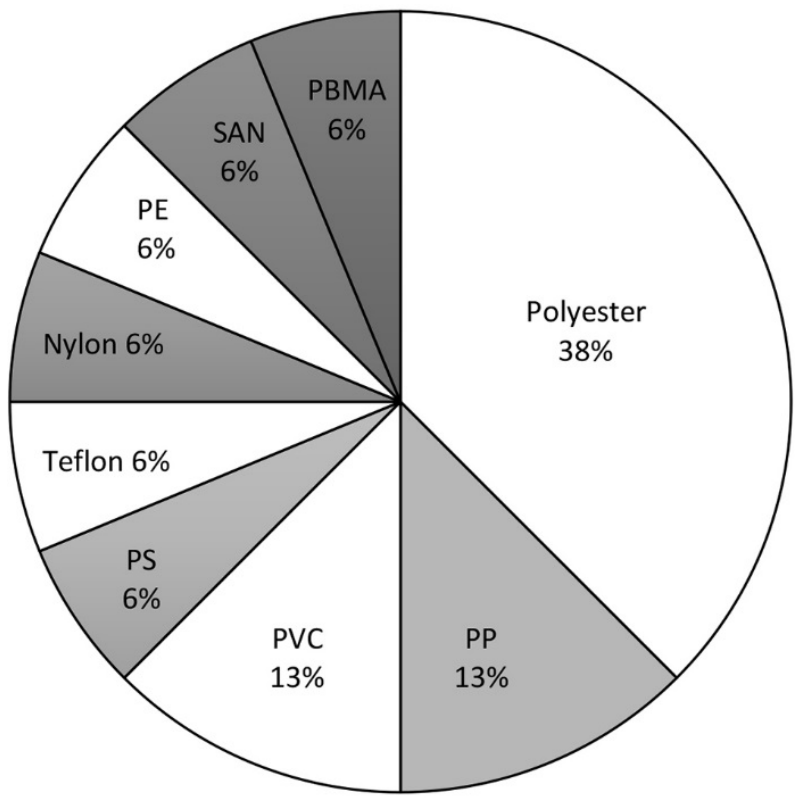

Figure 19: Examples of polymers found in Atlantic cod from Bergen city harbour (Bråte et al., 2016). From left: Polyester, Polyvinyl chloride, and Styrene acrylonitrile resin

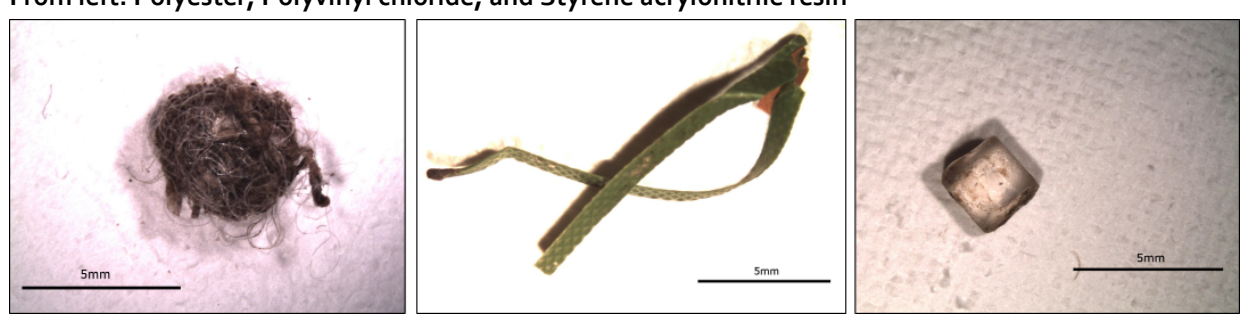

\subsection{Factors influencing microplastic ingestion in marine biota - Comparability of studies}

Comparability of studies, and factors affecting the levels of plastic ingestion in marine biota, can be influence by several aspects, such as ecology and different methods used. This section will discuss the comparability between groups of species including the cofounding factors and biases of plastic levels in biota. To be able to compare levels of 
plastic ingestion by biota sampled over different spatial and temporal periods, it is important to understand whether data can be compared.

\subsubsection{Fish}

It is difficult to compare levels of plastics found in fish from the Nordic environment with global levels, let alone between stations within the Nordic environment for several reasons as we will discuss in the following section. For example, fish ecology may influence the chances of interaction with plastics (Table 7). Furthermore, the feeding habitat (e.g. pelagic, demersal) or feeding type (e.g. filtration, scavenging) can also impact the levels and types of plastics that the biota can encounter. When data is presented by primary habitat type, there are only two species of fish that have information regarding plastic ingestion, the pelagic herring and the demersal cod. This highlights a significant need for increased studies on more species from pelagic and demersal habitats. Pelagic fish, as studied by Güven et al. (2017), contained higher numbers of plastics regardless of whether they are predatory species or not.

Table 7: Habitat information on fish species found to contain plastics in the Nordic area. C: coastal, O: offshore, B: both, St:stationary/MI: migratory/B:both

\begin{tabular}{|c|c|c|c|c|c|}
\hline Species name & $\begin{array}{l}\text { Primary } \\
\text { habitat }\end{array}$ & $\begin{array}{l}\text { Secondary } \\
\text { habitat }\end{array}$ & $\mathrm{C} / \mathrm{O} / \mathrm{B}$ & $\begin{array}{l}\text { Size (common length; max. } \\
\text { Weight) }\end{array}$ & St/Mi/B \\
\hline Herring & Pelagic & Demersal & Both & $30.0 \mathrm{~cm} ; 1.1 \mathrm{~kg}$ & Both \\
\hline Atlantic cod & Demersal & Pelagic & Both & $100.0 \mathrm{~cm} ; 96.0 \mathrm{~kg}$ & Both \\
\hline European flounder & Demersal & 1 & Coastal & $50.0 \mathrm{~cm} ; 2.9 \mathrm{~kg}$ & Migratory \\
\hline Atlantic mackerel & Pelagic & Demersal & Both & $30.0 \mathrm{~cm} ; 3.4 \mathrm{~kg}$ & Migratory \\
\hline Three-spined sticklebacks & Pelagic* & Demersal* & Coastal & $5.1 \mathrm{~cm}$ & Stationary \\
\hline Common dab & Demersal & 1 & Coastal & Maturity size range $13-25 \mathrm{~cm} ; 1.0 \mathrm{~kg}$ & Stationary \\
\hline Gray gurnard & Demersal & l & Coastal & $30.0 \mathrm{~cm} ; 956.00 \mathrm{~g}$ & Stationary \\
\hline Whiting & Demersal & l & Both & $23.5 \mathrm{~cm} ; 3.1 \mathrm{~kg}$ & Both \\
\hline European sprat & Pelagic & l & Coastal & $12.0 \mathrm{~cm}$ & Stationary \\
\hline Horse mackerel & Pelagic & 1 & Both & $22.0 \mathrm{~cm} ; 2.0 \mathrm{~kg}$ & Migratory \\
\hline Haddock & Demersal & Pelagic & Offshore & $35.0 \mathrm{~cm} ; 16.8 \mathrm{~kg}$ & Migratory \\
\hline European eelpout & Demersal & 1 & Coastal & $30.0 \mathrm{~cm} ; 510.00 \mathrm{~g}$ & Stationary \\
\hline Longspined bullhead & Demersal & l & Coastal & $12.0 \mathrm{~cm}$ & Stationary \\
\hline Twaite shad & Pelagic & l & Coastal & $40.0 \mathrm{~cm} ; 1.5 \mathrm{~kg}$ & Migratory \\
\hline
\end{tabular}

Note: $\quad$ * Life stage dependent, pelagic as adult.

Source: http://www.fishbase.org/search.php

Uptake of microplastics could be related to distance from urbanised locations, sources of input or sources of accumulation in the environment. Fish in coastal locations may be more exposed to localised urban sources and accumulations of microplastics, whereas those in offshore areas may be exposed to plastic though their prey or areas of plastic accumulation. On the other hand, organisms in open oceans may be exposed to less microplastics due to dilution of concentrations further away from sources. For example, Atlantic cod from the Norwegian coast, contained more microplastics in Bergen City harbour than any other Norwegian coastal area (Bråte et al., 2016). However, no microplastics were found in cod from the inner Oslofjord, which is surprising considering the high level of urbanization (Bråte et al., 2016). Coastal North Sea dab had high levels 
of plastic ingestion (Rummel et al., 2016) however, Lenz and colleagues (2013) unexpectedly found more microplastics in offshore cod and herring than coastal fish. At present, results have too large variation to say anything on spatial trends in the Nordic marine environment, however certain hot-spots like Bergen City harbour might exist. As the data on microplastics in the Nordic environment are less than substantial, increased knowledge of microplastic behaviour and spatial spread is required.

Trophic level has also been suggested to impact plastic ingestion (Boerger et al., 2010) but a recent study found that the trophic level did not influence the quantity of microplastics ingested (Güven et al., 2017). However, secondary ingestion may impact ingestion levels; since prey species may have already ingested plastic, and they may act as a vector for transfer of plastics between trophic levels. For example; microplastics could transfer from prey to fur seals (Eriksson \& Burton 2003) and this has also been demonstrated in the laboratory from mussels to crabs (Watts et al., 2014). Currently though, there is not enough information to conclude on potential trophic level interactions.

Age and size of fish have also been suggested to impact the levels of microplastics found in organisms. Larger fish may can ingest more plastics based on volume due to their larger body, but there is currently no empirical data to support this. On the other hand, larger fish may be better at excreting plastic from their stomach due to their physiology. Although, fish length, nor the mass of fish, did not appear to have any correlation with the number of ingested particles (Güven et al., 2017).

Another important aspect when considering the levels of microplastics found in fish, is the digestion stage at the time of capture or analysis. This may play an important role in the levels of plastics identified in gastrointestinal tracts. It has been suggested that the levels of food in the gastrointestinal tract, or stage of digestion, may affect microplastic presence (Bråte et al., 2016). Therefore, monitoring would only provide levels as a snap shot in time (Güven et al., 2017; see section 5 for more discussion on this).

Another parameter that might impact the ingestion rate of plastics is the fish spawning cycle. Fish can lose a lot of weight while spawning, for e.g. Twaite shad that can lose 30\% (male) and 50\% (females) of their body weight after spawning (Raabe \& Hightower, 2014) and the spawning cycle affects fish feeding behaviour during certain periods, which again may impact the amount of plastic ingested.

The methods used to identify levels of plastic polymers are also of importance, as already covered in section 3.1. Several different methods have been used for the Nordic studies, see Table 8 for methods. For the sampling, several factors might influence the ingested plastic levels. The different mesh used for capture when trawling (not given for most of the studies from the Nordic area), the contamination risk from the trawl due to its plastic material, various sizes of individuals sampled and time of sampling (FAO, in press).

As with larger marine organisms, the analysis of fish in the laboratory can be tricky, for example whole organisms cannot be dissolved in the same way as mussels, and extractions of stomach contents can be affected by contamination, and confounded by the size of the animal. However, there are necessary steps that researchers can use to optimise fish analysis in the laboratory (Lusher et al., 2017). It is important to establish 
best practises for sample collection and analysis, to reduce bias and be more suitable for long-term monitoring (see section 2). Recent research has also found that the levels of plastics found in fish depends on if the whole digestive tract is analysed, or just the stomach. Güven et al. (2017) found 1.81 microplastic particle per fish in the intestines, and this means that studying just the stomach and not the entire digestive tract, can lead to underestimation of the plastic ingestion levels of fish.

For the chemical identification of specific polymers, and thereby ensuring that the suspected particles are plastic, can also lead to biases. The visual identification is subjective and skill dependent, and only this method is used there may be over or underestimations. Staining methods like Nile Red Dye might reduce these difficulties (Maes et al., 2017), but also the more classical methods like FTIR and Raman spectroscopy.

Another important aspect is the contamination risk; see section 3.1 for more information. Encouragingly there has been a lot of focus on this aspect in recent years since when samples are analysed there is a high change of contamination with anthropogenic fibres.

Furthermore, if plastics are not classified effectively, there may be over or under estimates and the cut-off values when it comes to detection limit of microplastics vary from $100-500 \mu \mathrm{m}$ from the Nordic environment. Currently there is no information on fish ingesting particles smaller than $100 \mu \mathrm{m}$ from the Nordic marine area. 
Table 8: Methods used to detect plastics in the different marine biota from the Nordic environment. Sampling equals sampling method in the field, Method equals method in the laboratory, if FTIR (Fourier transform infrared spectroscopy) has been done and the detection limit in the study

\begin{tabular}{|c|c|c|c|c|c|c|c|}
\hline Organism & $\begin{array}{l}\text { Species } \\
\text { name }\end{array}$ & Sampling & Method & $\begin{array}{l}\text { Part of organism } \\
\text { studied }\end{array}$ & FTIR & $\begin{array}{l}\text { Cut- } \\
\text { off } \\
(\mu \mathrm{m})\end{array}$ & Reference \\
\hline Fish & Atlantic cod & Trawl & Visual & Stomach & Yes & 100 & Bråte et al. \\
\hline Fish & Atlantic cod & Trawl & $\begin{array}{l}\mathrm{KOH} \\
\text { digestion and } \\
\text { visual }\end{array}$ & $\begin{array}{l}\text { Gastrointestinal tract } \\
\text { (GIT) content }\end{array}$ & Yes-some & 200 & Foekema et al. \\
\hline Fish & Atlantic cod & I & $\begin{array}{l}10 \% \mathrm{KOH} \text { and } \\
14 \% \mathrm{NaClO} \\
\text { and visual }\end{array}$ & Stomach & $\begin{array}{l}\text { Raman } \\
\text { Analysis of } \\
\text { some }\end{array}$ & 100 & Lenz et al. \\
\hline Fish & Atlantic cod & Trawl & Visual & $\begin{array}{l}\text { Gastrointestinal tract } \\
\text { (GIT) }\end{array}$ & Yes & 180 & Rummel et al. \\
\hline Fish & Atlantic cod & Trawl & Visual & $\begin{array}{l}\text { Gastrointestinal tract } \\
\text { (GIT) }\end{array}$ & Yes & 180 & Rummel et al. \\
\hline Fish & $\begin{array}{l}\text { Atlantic } \\
\text { herring }\end{array}$ & Trawl & Visual* & $\begin{array}{l}\text { Gastrointestinal tract } \\
\text { (GIT) }\end{array}$ & Yes & 180 & Rummel et al. \\
\hline Fish & $\begin{array}{l}\text { Atlantic } \\
\text { herring }\end{array}$ & Trawl & $\begin{array}{l}\mathrm{KOH} \\
\text { digestion and } \\
\text { visual }\end{array}$ & $\begin{array}{l}\text { Gastrointestinal tract } \\
\text { (GIT) content }\end{array}$ & Yes-some & 200 & Foekema et al. \\
\hline Fish & $\begin{array}{l}\text { Atlantic } \\
\text { herring }\end{array}$ & Trawl & $\begin{array}{l}10 \% \mathrm{KOH} \text { and } \\
14 \% \mathrm{NaClO} \\
\text { and visual }\end{array}$ & Entrails & No & 500 & Sørensen et al. \\
\hline Fish & $\begin{array}{l}\text { Atlantic } \\
\text { herring }\end{array}$ & I & $\begin{array}{l}10 \% \mathrm{KOH} \text { and } \\
14 \% \mathrm{NaClO} \\
\text { and visual }\end{array}$ & Stomach & $\begin{array}{l}\text { Raman } \\
\text { Analysis of } \\
\text { some }\end{array}$ & 100 & Lenz et al. \\
\hline Fish & $\begin{array}{l}\text { Atlantic } \\
\text { mackerel }\end{array}$ & Trawl & $\begin{array}{l}\mathrm{KOH} \\
\text { digestion and } \\
\text { visual }\end{array}$ & $\begin{array}{l}\text { Gastrointestinal tract } \\
\text { (GIT) content }\end{array}$ & No & 200 & Foekema et al. \\
\hline Fish & $\begin{array}{l}\text { Atlantic } \\
\text { mackerel }\end{array}$ & Trawl & Visual & $\begin{array}{l}\text { Gastrointestinal tract } \\
\text { (GIT) }\end{array}$ & Yes & 180 & Rummel et al. \\
\hline Fish & $\begin{array}{l}\text { Common } \\
\text { dab }\end{array}$ & Trawl & Visual & $\begin{array}{l}\text { Gastrointestinal tract } \\
\text { (GIT) }\end{array}$ & Yes & 180 & Rummel et al. \\
\hline Fish & $\begin{array}{l}\text { European } \\
\text { flounder }\end{array}$ & Trawl & Visual & $\begin{array}{l}\text { Gastrointestinal tract } \\
\text { (GIT) }\end{array}$ & Yes & 180 & Rummel et al. \\
\hline Fish & Twaite shad & Trawl & Visual & Stomach & I & I & Skóra et al. \\
\hline Fish & Whiting & Trawl & $\begin{array}{l}\mathrm{KOH} \\
\text { digestion and } \\
\text { visual }\end{array}$ & $\begin{array}{l}\text { Gastrointestinal tract } \\
\text { (GIT) content }\end{array}$ & Yes-some & 200 & Foekema et al. \\
\hline Fish & Whiting & Trawl & $\begin{array}{l}10 \% \mathrm{KOH} \text { and } \\
14 \% \mathrm{NaClO} \\
\text { and visual }\end{array}$ & Entrails & No & 500 & Sørensen et al. \\
\hline Fish & $\begin{array}{l}\text { Gray } \\
\text { gurnard }\end{array}$ & Trawl & $\begin{array}{l}\mathrm{KOH} \\
\text { digestion and } \\
\text { visual }\end{array}$ & $\begin{array}{l}\text { Gastrointestinal tract } \\
\text { (GIT) content }\end{array}$ & Yes-some & 200 & Foekema et al. \\
\hline
\end{tabular}




\begin{tabular}{|c|c|c|c|c|c|c|c|}
\hline Organism & $\begin{array}{l}\text { Species } \\
\text { name }\end{array}$ & Sampling & Method & $\begin{array}{l}\text { Part of organism } \\
\text { studied }\end{array}$ & FTIR & $\begin{array}{l}\text { Cut- } \\
\text { off } \\
(\mu \mathrm{m})\end{array}$ & Reference \\
\hline Fish & Haddock & Trawl & $\begin{array}{l}\mathrm{KOH} \\
\text { digestion and } \\
\text { visual }\end{array}$ & $\begin{array}{l}\text { Gastrointestinal tract } \\
\text { (GIT) content }\end{array}$ & No & 200 & Foekema et al. \\
\hline Fish & $\begin{array}{l}\text { Horse } \\
\text { mackerel }\end{array}$ & Trawl & $\begin{array}{l}\mathrm{KOH} \\
\text { digestion and } \\
\text { visual }\end{array}$ & $\begin{array}{l}\text { Gastrointestinal tract } \\
\text { (GIT) content }\end{array}$ & Yes-some & 200 & Foekema et al. \\
\hline Fish & Atlantic cod & Trap & $\begin{array}{l}\text { Different } \\
\text { digestions } \\
\text { and visual }\end{array}$ & $\begin{array}{l}\text { Gastrointestinal tract } \\
\text { (GIT) }\end{array}$ & $\begin{array}{l}\text { Yes, but no } \\
\text { results } \\
\text { given }\end{array}$ & I & Agersnap \\
\hline Fish & $\begin{array}{l}\text { European } \\
\text { flounder }\end{array}$ & Trap & $\begin{array}{l}\text { Different } \\
\text { digestions } \\
\text { and visual }\end{array}$ & $\begin{array}{l}\text { Gastrointestinal tract } \\
\text { (GIT) }\end{array}$ & $\begin{array}{l}\text { Yes, but no } \\
\text { results } \\
\text { given }\end{array}$ & l & Agersnap \\
\hline Fish & $\begin{array}{l}\text { European } \\
\text { flounder }\end{array}$ & Trap & $\begin{array}{l}\text { Different } \\
\text { digestions } \\
\text { and visual }\end{array}$ & $\begin{array}{l}\text { Gastrointestinal tract } \\
\text { (GIT) }\end{array}$ & $\begin{array}{l}\text { Yes, but no } \\
\text { results } \\
\text { given }\end{array}$ & l & Agersnap \\
\hline Fish & $\begin{array}{l}\text { Longspined } \\
\text { bullhead }\end{array}$ & Trap & $\begin{array}{l}\text { Different } \\
\text { digestions } \\
\text { and visual }\end{array}$ & $\begin{array}{l}\text { Gastrointestinal tract } \\
\text { (GIT) }\end{array}$ & $\begin{array}{l}\text { Yes, but no } \\
\text { results } \\
\text { given }\end{array}$ & l & Agersnap \\
\hline Bivalve & $\begin{array}{l}\text { Iceland } \\
\text { Cockle }\end{array}$ & Unknown & $\begin{array}{l}\mathrm{H}_{2} \mathrm{SO}_{4} \\
\text { digestion and } \\
\text { visual }\end{array}$ & Digestive system & No & & Sundet \\
\hline Bivalve & $\begin{array}{l}\text { Blue } \\
\text { mussels }\end{array}$ & Caged & $\begin{array}{l}\mathrm{H}_{2} \mathrm{SO}_{4} \\
\text { digestion and } \\
\text { visual }\end{array}$ & Digestive system & No & & Sundet \\
\hline Bivalve & Blue mussel & Picked & $\begin{array}{l}65 \% \mathrm{HNO}_{3} \\
\text { and visual }\end{array}$ & Whole individual & No & l & Gustafsson \\
\hline Bivalve & Blue mussel & Picked & $\begin{array}{l}\text { Different } \\
\text { digestions } \\
\text { and visual }\end{array}$ & Whole individual & $\begin{array}{l}\text { Yes, but no } \\
\text { results } \\
\text { given }\end{array}$ & l & Agersnap \\
\hline Bivalve & Blue mussel & $\begin{array}{l}\text { Shop } \\
\text { (cultivated) }\end{array}$ & $\begin{array}{l}\text { Different } \\
\text { digestions } \\
\text { and visual }\end{array}$ & Whole individual & No & l & Vandermeersch \\
\hline $\begin{array}{l}\text { Marine } \\
\text { worms }\end{array}$ & Lugworrm & $\begin{array}{l}\text { Grab } \\
\text { samples }\end{array}$ & $\begin{array}{l}10 \mathrm{M} \mathrm{NaOH} \\
\text { digestion }\end{array}$ & Digestive system & For some* & l & Haave \\
\hline Crustacean & $\begin{array}{l}\text { Chinese } \\
\text { mitten crab }\end{array}$ & Fyke-nets & Visual & Stomach & No & l & Wójcik-Fudalewska \\
\hline Crustacean & Snow-crab & Fyke-nets & Visual & Stomach & No & l & Skora et al \\
\hline
\end{tabular}

Note: * Found polystyrene. Did also find possible anthropogenic fibers in Chaetozone jubata, Pectinaria belgica and Pectinaria auricoma. With same method. 


\subsubsection{Invertebrates}

Studying comparability between invertebrates, particularly bivalves, is easier than fish for several reasons, and will be discussed in more depth in section 5 .

Comparing the levels found of microplastics in mussels from the Nordic area is difficult since most of the studies are pilot studies with a small number of samples and the methods used are poorly described. For invertebrates, there are three small-scale studies from the Nordic area, none of which are peer-reviewed. It is therefore suggested that there is a strong focus on investigating the levels of microplastics in invertebrates from the Nordic marine environment, particularly on the replicability and standardisation of methods.

To clearly see any trends, either temporal or spatial in the amount of microplastic ingested by invertebrates, the variability between individuals must first be understood. Information on variations should be used to choose the appropriate sample size in a study. From the total available literature on the level of microplastics found in mussels, very little information is available on this variance between individuals considering plastic content. A reason for this is that several mussel studies use pooled individuals (for e.g. analysing 10 individuals as one big sample) and this is also the case for most of the studies from the Nordic environment. The variation in the microplastic levels might also be impacted by designation, for example Li et al. (2015) found that if they presented their microplastic levels based on "number of microplastic found per $\mathrm{g}$ wet weight", instead of presenting it as microplastic found per individual, they reduced the variation. Therefore, the data for all studies should give both the levels per gram and per individual.

For marine worms and snow crabs, the empirical data is even smaller than bivalves, and therefore it is difficult to understand the comparability of studies on these species from the Nordic marine environment. 



\title{
5. Biomarker selection for microplastic monitoring
}

\begin{abstract}
When discussing selection of a suitable fish species for the Nordic environment, there are a limited empirical data to provide sufficient species recommendations. Cod, herring and mackerel, one demersal and two pelagic species, are abundant and commercially important within Nordic countries and could be used as biomonitor species. Bivalves fulfil many of the criteria required for a biomonitor species, and some of the main advantages over fish is that they are sessile and much easier to process with more standardised methods available. Benthic dwelling organisms, particularly marine worms, have the potential for monitoring plastics. Arenicola marina is suggested as a suitable species because it is already used for biomonitoring and is abundant in the marine environment, and laboratory studies have already shown individuals are affected by microplastic exposure.
\end{abstract}

To understand the impact on plastic pollution in marine biota from the Nordic environment, it is first necessary to establish the amount of plastics being ingested, and how this ingestion can affect biota. One approach could be to monitor the environment using so-called bioindicators or biomarkers. The terms "bioindicator" and "biomarker" are not easy to separate in the scientific literature (Van Gestel \& Van Brummelen, 1996) and are often used interchangeably. A thorough review of both terms is provided by Van Der Oost et al. (2003). Broadly speaking, the use of a biomarker includes almost any measurement showing an interaction with a biological system and a potential hazard (chemical, physical or biological) (WHO, 1993), while bioindicators are defined as "an organism giving information on the environmental conditions of its habitat by its presence or absence or by its behaviour" (Van Gestel \& Van Brummelen, 1996). On understanding both descriptions, the term biomarker might be a more suitable term for microplastic monitoring.

When considering effects from a "classical chemical", effects are dependent on the concentration, toxicity, solubility, bioavailability, and duration of exposure, as well as the sensitivity of the exposed organisms (Connon et al., 2012). Since microplastics do not behave like typical environmental pollutants, for example regarding water solubility and toxicity, it is a challenge to find good biomarkers based on classical toxicological assessments. Recently, a discussion emerged as to whether microplastics should be defined as a persistent organic pollutants (POP) (Lohmann, 2017). Lohmann states that we can consider classifying microplastics as potential pollutants under the Stockholm Convention on POPs (UNEP, 2001), but the specific microplastic or polymer must meet four criteria: 
- Persistence.

- Long-range transport.

- Bioaccumulation.

- Adverse effects.

Current understanding is that plastics are persistent in the environment due to their inert nature (Gewert et al., 2015), even if they become brittle and fragment, the particles will remain in the environment in a smaller size. Furthermore, plastics can be transported over long ranges, as is evidenced by accumulation of plastics in areas far from the source locations (Law et al., 2010; van Sebille et al., 2015). However, there is limited and insufficient knowledge on bioaccumulation and adverse effects of plastics (Rochman, Browne et al., 2013). Until greater understanding of the bioaccumulation and potential adverse effects of microplastics on organisms is achieved it cannot be concluded whether all the criteria are met.

As microplastics can differ in their properties based on polymer and additive composition, shape and size which may be challenging to characterise (Lambert et al., 2017; Potthoff et al., 2017). Most microplastic toxicity studies conducted using uniform microplastics, such that they use microplastics of a known polymer and size to set a threshold. Some effects of microplastics and their associated chemicals have been monitored, but there is limited knowledge on "microplastic-only effects". For example, polypropylene (PP) fibres were more harmful to the amphipod Hyalella azteca, than polyethylene (PE) beads (Au et al., 2015). However, in this specific study it is not possible to separate whether particle shape or polymer type affect the outcome. Additionally, polyvinyl chloride (PVC) is thought to be the most problematic polymer due to high chloride and additive content, by weight, (Lambert et al., 2017), and might be a higher risk to the environment than other polymers. These examples show us that we need to broaden the exposure studies to test toxicity of microplastics.

Another requirement is the use of environmental realistic concentrations, to allow for effectively extrapolating toxicity studies to wild biota. There is currently a scientific debate on utilizing positive particle controls for microplastic exposure studies. At this point it is impossible to distinguish between effects of microplastic exposure from with general particle toxicity. Such that, effects observed in laboratory studies may or may not occur if exposing organisms to naturally occurring particles, i.e. sand, in the same size range. For example, effects observed in blue mussels ( $M$. edulis) following exposure to microplastics included increased energy consumption (25\%) in the digestive gland (Van Cauwenberghe et al., 2015) and tissue alterations in the digestive gland (von Moos et al., 2012), but these studies did not include any positive control. Furthermore, it is also important to see how weathering of microplastics are affecting their uptake (Hartmann et al., 2017). As an example, a study on microplastic ingestion in blue mussels found increased uptake of weathered PE particles compared to virgin (i.e. not weathered) PE particles (Bråte et al., under review).

Since the knowledge base regarding effects from plastic exposure contains many uncertainties, it is hard to discuss suitable biomarkers for plastic pollution effects in the 
marine environment. However, current knowledge on the levels and presence of plastics can be used to discuss possible biomarkers for plastic ingestion for geographical regions. In the Nordic environment, however, data on MPs levels within biota is insufficient as so few studies have been conducted.

In addition, there are many different methods used for biota studies which makes the empirical data even more uncertain (see section 4.4). Best practice protocols are required to monitor plastic particles in biota (OSPAR 2015). Monitoring the presence of plastics in biota are important to establish that uptake is occurring, however, future monitoring of only presence of plastic in the environment is not sufficient, since an understanding of the implications of ingestion on biota are required, in particular to ecologically important species, and species which could present a health risk if consumed by humans.

A recent EU-project, Clean Sea aimed to identify bio-indicators for plastic ingestion. It listed criteria for good bio-indicator species (CleanSea, 2017) (http://www.cleanseaproject.eu/drupal/sites/default/files/project\%2oresults/D2_2_factsheet.pdf), however the project did not make any specific recommendations for species. It is important to follow the similar criteria as suggested by Clean Sea to achieve a holistic approach and agreement between researchers on which species should be assessed. Utilising the criteria from Clean Sea, and through personal experience of the authors a list of criteria (albeit ambitious) has been compiled.

Suggestions of criteria for biomarkers used for plastic monitoring:

- Region-specific indicator species or species can be kept in cages and confined (e.g. caged mussels).

- Ethical considerations (e.g. not use species that are threatened or protected).

- Cost of sampling/analysing the biota - sampling simultaneously for other pollutants and merging with other programmes.

- Species that are directly linkable to impact and effects.

- Species should be commercially and ecologically important.

- Species should together cover several ecological niches: pelagic, demersal and benthic.

- Species should cover several feeding strategies (e.g. filter feeders, scavengers etc.).

- Ease of practical to analyse in the laboratory (e.g. invertebrates easier than vertebrates).

- Species should be abundant in the environment and easy to sample.

- Species are already used as bioindicator/biomonitor.

- Can be comparable to global studies (global range).

- If possible, non-invasive methods (for higher phyla such as mammals this includes the collect faeces, or carcasses). 
Specific criteria for a good biomonitor for plastics in the Nordic environment:

- Should be abundant in the Nordic area.

- Should already been found to contain microplastics, preferably in the Nordic Environment.

\subsection{Biomarker selection}

The following section is based on the authors interpretations as the database is limited, as will be discussed and therefore these are only initial recommendations. As the knowledge base widens it might be appropriate to change to a better species. The authors suggest that there is a need to have a broad scientific debate on this topic. In table 9 and 10 we summarise the use of different phyla for biomarkers/bioindicators, and try to summarise how suitable these might be. This is however a big debate, and these suggestions should be considered as an input to the ongoing debate.

For lower trophic phyla, bivalves (e.g. blue mussels), crustaceans (e.g. Norway Lobster) annelids (e.g. Lug worm) together with all the phytoplankton could be suitable biomarkers. However, for microplastics investigations, the likelihood for phytoplankton to ingest microplastics are small due to their small size. They might be more suitable to monitor nanoparticles. Mackerel, Atlantic cod and Herring could be suitable biomonitors for fish, however, as stated earlier, we still need to assess this broader to conclude on this.

In the following section, recommendations based on the following biota (i) Fish, (ii), invertebrates, are proposed. 
Table 9: Understanding the suitability for groups of species to act as a bioindicators/biomonitor in the Nordic environment. Table presents potential indicator species and their suitability as indicators

\begin{tabular}{|c|c|c|c|c|c|c|c|c|}
\hline & \multicolumn{3}{|c|}{ Phytoplankton } & \multicolumn{2}{|c|}{ Zooplankton } & \multicolumn{2}{|c|}{ Shellfish } & \multirow{2}{*}{$\begin{array}{l}\begin{array}{l}\text { Other } \\
\text { inverte- } \\
\text { brates }\end{array} \\
\text { Annelids }\end{array}$} \\
\hline & $\begin{array}{l}\text { Cyano- } \\
\text { bacteria }\end{array}$ & Flagellates & Diatoms & Copepods & Cnidaria & Bivalves & Crustaceans & \\
\hline Example species* & $\begin{array}{l}\text { Rhodomo } \\
\text { nas salina }\end{array}$ & & $\begin{array}{l}\text { Chaetoceros } \\
\text { neogracile }\end{array}$ & $\begin{array}{l}\text { Calanus } \\
\text { helgolandicus }\end{array}$ & & $\begin{array}{l}\text { Mytilus } \\
\text { edulis }\end{array}$ & $\begin{array}{l}\text { Nephrops } \\
\text { norvegicus }\end{array}$ & $\begin{array}{l}\text { Arenicola } \\
\text { marina }\end{array}$ \\
\hline Ecological niche & Planktonic & Planktonic & Planktonic & $\begin{array}{l}\text { Planktonic, } \\
\text { Benthic }\end{array}$ & $\begin{array}{l}\text { Pelagic } \\
\text { Benthic } \\
\text { Sessile }\end{array}$ & $\begin{array}{l}\text { Benthic } \\
\text { sessile }\end{array}$ & Benthic & Benthic \\
\hline $\begin{array}{l}\text { Feeding strategies } \\
\text { (e.g. filter feeders, } \\
\text { scavengers) }\end{array}$ & Producer & Producer & Producer & Filter feeding & $\begin{array}{l}\text { Filter } \\
\text { feeding }\end{array}$ & $\begin{array}{c}\text { Filter } \\
\text { feeding }\end{array}$ & Scavengers & Detritivore \\
\hline \multicolumn{9}{|l|}{ Key requirements } \\
\hline Sessile & $\mathrm{N}$ & $\mathrm{N}$ & $\mathrm{N}$ & $\mathrm{N}$ & $\mathrm{N}$ & Y & $\begin{array}{l}Y \text { (to some } \\
\text { extent) }\end{array}$ & $\begin{array}{l}Y \text { (to some } \\
\text { extent) }\end{array}$ \\
\hline $\begin{array}{l}\text { Globally distributed } \\
\text { (or similar species } \\
\text { available)? }\end{array}$ & $\mathrm{Y}$ & $\mathrm{Y}$ & Y & $\mathrm{Y}$ & Y & Y & $\mathrm{Y}$ & Y \\
\hline $\begin{array}{l}\text { Ethically sound (not } \\
\text { threatened or } \\
\text { protected)? }\end{array}$ & $\mathrm{Y}$ & $\mathrm{Y}$ & $\mathrm{Y}$ & $\mathrm{Y}$ & $\mathrm{Y}$ & $Y$ & $\mathrm{Y}$ & $\mathrm{Y}$ \\
\hline $\begin{array}{l}\text { Already used as a bio } \\
\text { indicator? }\end{array}$ & $\mathrm{Y}$ & $\mathrm{Y}$ & $\mathrm{Y}$ & $N * *$ & $N * *$ & Y & $\mathrm{Y}$ & $\mathrm{Y}$ \\
\hline $\begin{array}{l}\text { Abundant in the } \\
\text { environment and } \\
\text { easy to sample? }\end{array}$ & $\mathrm{Y}$ & $\mathrm{Y}$ & Y & Y & Y & $Y * * *$ & Y & Y \\
\hline $\begin{array}{l}\text { Low cost of sampling } \\
\text { and can be carried out } \\
\text { simultaneously of } \\
\text { other pollutants? }\end{array}$ & $\mathrm{Y}$ & $\mathrm{Y}$ & $\mathrm{Y}$ & Y & unknown & $\mathrm{Y}$ & $\mathrm{Y}$ & $\mathrm{Y}$ \\
\hline $\begin{array}{l}\text { Found effects in } \\
\text { laboratory studies? }\end{array}$ & $\mathrm{Y}$ & $\mathrm{Y}$ & Y & $\mathrm{Y}$ & $\begin{array}{l}\text { Not } \\
\text { studied } \\
\text { effects }\end{array}$ & $Y$ & $\mathrm{Y}$ & $\mathrm{Y}$ \\
\hline $\begin{array}{l}\text { Commercially } \\
\text { important? }\end{array}$ & $\mathrm{N}$ & $\mathrm{N}$ & $\mathrm{N}$ & $\mathrm{N}$ & $\mathrm{N}$ & $\mathrm{Y}$ & $\mathrm{Y}$ & $\mathrm{N}$ \\
\hline $\begin{array}{l}\text { Ease of analysis in } \\
\text { laboratory? }\end{array}$ & Y & $\mathrm{Y}$ & Y & $Y$ & Y & $\mathrm{Y}$ & $\mathrm{N}$ & $\mathrm{Y}$ \\
\hline $\begin{array}{l}\text { Example of use in } \\
\text { plastic studies }\end{array}$ & $\begin{array}{l}\text { Long et al. } \\
\qquad 2015\end{array}$ & $\begin{array}{l}\text { Cole et al. } \\
2013\end{array}$ & $\begin{array}{l}\text { Long et al. } \\
\qquad 2015\end{array}$ & $\begin{array}{l}\text { Cole et al. } \\
2013\end{array}$ & $\begin{array}{l}\text { Taylor et } \\
\text { al. } 2016\end{array}$ & $\begin{array}{l}\text { Liet al. } \\
2016\end{array}$ & $\begin{array}{l}\text { Welden \& } \\
\text { Cowie } 2016\end{array}$ & $\begin{array}{l}\text { Wright et al. } \\
2013\end{array}$ \\
\hline
\end{tabular}

Note: * Intended to be used as an example species -Needs to be carefully considered with further research.

** As far as we know.

$* * *$ Have been found to decline in some areas. 
Table 10: Understanding the suitability for groups of species to act as a bioindicators/biomonitor in the Nordic environment. Table presents potential indicator species and their suitability as indicators

\begin{tabular}{|c|c|c|c|c|c|c|c|}
\hline & \multicolumn{2}{|c|}{ Marine mammals } & \multirow{2}{*}{$\begin{array}{l}\text { Birds } \\
\text { Procellariforms }\end{array}$} & \multirow[b]{2}{*}{ Cod } & \multicolumn{2}{|c|}{ Fish } & \multirow[b]{2}{*}{ Larger fish } \\
\hline & Baleen whales & $\begin{array}{l}\text { Toothed } \\
\text { whales, } \\
\text { dolphins }\end{array}$ & & & Mackerel & Herring & \\
\hline Example & $\begin{array}{c}\text { Balaenoptera } \\
\text { physalus, Megaptera } \\
\text { novaeangliae }\end{array}$ & Delphinus sp. & $\begin{array}{l}\text { Fulmarus } \\
\text { glacialis }\end{array}$ & $\begin{array}{l}\text { Gadus } \\
\text { morhua }\end{array}$ & Scomber sp. & Clupea harengus & $\begin{array}{l}\text { shark or } \\
\text { tuna }\end{array}$ \\
\hline Ecological niche & Pelagic Deep pelagic & $\begin{array}{l}\text { Pelagic Deep } \\
\text { pelagic }\end{array}$ & Pelagic & $\begin{array}{l}\text { Pelagic, } \\
\text { demersal }\end{array}$ & Pelagic & Pelagic & Pelagic \\
\hline $\begin{array}{l}\text { Feeding strategies (e.g. } \\
\text { filter feeders, scavengers) }\end{array}$ & $\begin{array}{l}\text { Filter feeding, ram } \\
\text { feeding, bubble } \\
\text { feeding }\end{array}$ & Predator & Predator & $\begin{array}{l}\text { Scavenger, } \\
\text { predatory }\end{array}$ & $\begin{array}{c}\text { Filter feeding, } \\
\text { opportunistic } \\
\text { particulate feeding }\end{array}$ & $\begin{array}{c}\text { Filter feeding, } \\
\text { opportunistic } \\
\text { particulate feeding }\end{array}$ & $\begin{array}{c}\text { Ram, } \\
\text { predatory }\end{array}$ \\
\hline \multicolumn{8}{|l|}{ Key requirements: } \\
\hline Sessile & $\mathrm{N}$ & $\mathrm{N}$ & $\mathrm{N}$ & $\mathrm{N}$ & $\mathrm{N}$ & $\mathrm{N}$ & $\mathrm{N}$ \\
\hline $\begin{array}{l}\text { Globally distributed (or } \\
\text { similar species } \\
\text { available)? }\end{array}$ & $\mathrm{Y}$ & Y & $\mathrm{Y}$ & $\mathrm{Y}$ & Y & $\mathrm{Y}$ & Y \\
\hline $\begin{array}{l}\text { Ethically sound (not } \\
\text { threatened or } \\
\text { protected)? }\end{array}$ & $N *$ & $N *$ & $N *$ & $y / n * *$ & Not sure & Y & $\mathrm{N}$ \\
\hline $\begin{array}{l}\text { Already used as a bio } \\
\text { indicator? }\end{array}$ & $N$ & $N$ & $\mathrm{Y}$ & Y & Not sure & Y & Y \\
\hline $\begin{array}{l}\text { Abundant in the } \\
\text { environment and easy to } \\
\text { sample? }\end{array}$ & $\mathrm{N}$ & $\mathrm{N}$ & $\mathrm{N}$ & Y & Y & Y & $\mathrm{N}$ \\
\hline $\begin{array}{l}\text { Low cost of sampling / } \\
\text { carried out } \\
\text { simultaneously of other } \\
\text { pollutants? }\end{array}$ & $N / Y^{*}$ & $N / Y *$ & $N / Y *)$ & $\mathrm{Y}$ & Y & $\mathrm{Y}$ & $\mathrm{N}$ \\
\hline $\begin{array}{l}\text { Found effects in } \\
\text { laboratory studies? }\end{array}$ & Not studied & Not studied & Not studied & Not studied & Not studied & Not studied & $\begin{array}{c}\text { Not } \\
\text { studied }\end{array}$ \\
\hline $\begin{array}{l}\text { Commercially } \\
\text { important? }\end{array}$ & $\mathrm{N}$ & $\mathrm{N}$ & $\mathrm{N}$ & Y & $\mathrm{Y}$ & $\mathrm{Y}$ & $\mathrm{Y} / \mathrm{N}$ \\
\hline $\begin{array}{l}\text { Ease of analysis in } \\
\text { laboratory? }\end{array}$ & $\mathrm{N}$ & $\mathrm{N}$ & $Y$ & $\begin{array}{l}\text { Y (depend } \\
\text { on diet) }\end{array}$ & Y & $\mathrm{Y}$ & $\mathrm{N}$ \\
\hline $\begin{array}{l}\text { Example of use in plastic } \\
\text { studies already? }\end{array}$ & Besseling et al. 2015 & $\begin{array}{l}\text { Lusher et al. } \\
\qquad 2015\end{array}$ & $\begin{array}{c}\text { Kühn \& van } \\
\text { Franeker } 2012\end{array}$ & $\begin{array}{l}\text { Bråte et al. } \\
\quad 2016\end{array}$ & $\begin{array}{c}\text { Rummel et al. } \\
2016\end{array}$ & Foekema et al. 2013 & $\begin{array}{l}\text { Romeo et } \\
\text { al. } 2015\end{array}$ \\
\hline
\end{tabular}

Note: * Already dead/stranded

** Depending on location

\subsubsection{Fish}

Fish are often used to monitor toxic substances in the environment (Van Der Oost et al., 2003) and might also be suitable as a biomonitors for plastic pollution in the aquatic environment. From the literature available on plastic ingestion in fish (section 2.4), and 
from those collected for this report (section 4.3), it is currently not possible to give any clear recommendation on specific fish species as an indicator for microplastic pollution from the Nordic area. From the Nordic area, only eight fish studies have been conducted, and many of the studies are not extensive. There are also inconsistencies in method used, and comparisons between the studies are not possible. It is therefore proposed that Nordic countries focus on screening several fish species from different environmental matrixes, with a priority focusing on method standardization. For example, Baltic and Atlantic Herring, Atlantic cod and Mackerel are abundant species in the Nordic marine environment, occupy different habitats and have different feeding habits. In general, the species are not region specific, but are abundant and widespread and there are populations in other global seas which will allow comparisons to global levels. They are also species being used as bioindicators for other monitoring programs such as Atlantic cod for Norwegian Contaminants in coastal waters of Norway (MILKYS, on behalf of Norwegian Environment Agency), and Baltic Herring is also one of the most used indicator species for contaminant monitoring in the Helsinki Commission (HELCOM).

Unfortunately, as with all motile species, fish cannot be confined in the study area, and may represent a more transient description of microplastics in the environment. For example, the gut clearance of plastics needs to be understood, as discussed in section 4.4. For North Sea cod, the general gut retention time (GRT) has been estimated to be 3.7 days (Daan, 1973) and 4 days (Santos \& Jobling, 1991). We do not know if the clearance of plastics is similar to other non-dietary items, but current findings suggest that the presence of plastic items corresponds to the presence of food items, since it seems to be more plastics in fish with full stomachs (Bråte et al., 2016) and a recent laboratory study with Goldfish (Carassius auratus) found that the fish did clear the ingested plastic similarly to food items (Grigorakis et al., 2017). If plastics are not accumulated over time, fish that are local to an area might be more suitable to monitor plastic pollution than migratory fish. Atlantic cod can be both stationary (to a certain extent) and migratory so it is recommended that stationary cod populations are monitored to better represent an area. All cod, herring and mackerel are species that are of commercial importance to Nordic countries, as fish in general are an important part of the Nordic diet. Therefore, these species may provide information on potential implications for consumers.

There are also other fish species studied in other monitoring studies from the Nordic environment that could be suitable as a biomonitor. For example, Eelpout, which was also found to contain plastic from the Nordic environment, however, they are protected and might therefore not be the best species to study.

\subsubsection{Invertebrates}

Bivalves are a group of invertebrates that in general fulfil many of the criteria listed above for choice of biomonitor species, and one of the main advantages with bivalves being used as a bio-indicator in contrast to fish, is that they are sessile. Bivalves includes mussels (Mytilus sp.) which have been suggested as bioindicator by ICES for 
microplastic pollution in the water column and coastal areas (OSPAR, 2015). Blue mussels have a clearly defined ecological niche in the pelagic environment and are abundant in intertidal and coastal locations worldwide. They filter large volumes of seawater and are relatively easy to sample due to their habitat. Blue mussels are already used to monitor contaminants for large scale surveillance studies such as the Norwegian MILKYS (CEMP/JAMP) as well as international level monitoring, for example the American "Mussel Watch Program". They are easy and relatively cheap to sample and can also be confined to a study area. Their sampling can be carried out simultaneously when looking for other pollutants.

As with fish, it is still not possible to confirm a direct link between microplastic ingestion and effects on wild mussels, despite laboratory studies have found effects such as alterations in tissue of mussels, see section 2.4. There are several methodological advantages to using mussels in place of fish or larger organisms. For example, the ability to digest the whole individual with $\mathrm{KOH}$ solution, are reducing the level of subjectivity when doing visual analysis. In addition, the method is much faster than for fish studies, giving us the ability to analyse a higher number of individual for lower cost. Mussels are ecologically and commercially important and from a human food safety aspect (the entire organisms are consumed whole) should be a focus of monitoring studies.

Crustaceans are considered valuable in monitoring studies, and crustaceans are highly vulnerable to water-borne chemicals are particularly prone to accumulating chemical contaminants (Bilyard, 1987). For the moment, minimal crustaceans have been studied from the Nordic environment, but they could provide useful information of plastic pollution.

A lot of the plastics found in the environment is on the sea floor and organisms living within the sediment should be investigated as they may play a role in the distribution of plastics in the sediment. Therefore, we must investigate how sediment dwelling organisms living in, and of, sediment is impacted by plastic pollution. There are many species around the world although there are region specific populations which allows comparisons to occur on a global scale, and they are considered useful to monitor plastic pollution (e.g. Green et al., 2016). Marine worms are not threatened or protected and some species are already used as bioindicators, such as the coastal lugworm Arenicola marina (Hannam et al., 2008). Arenicola marina are abundant and can be easily sampled at low cost, and it has been found that it can stand for as much as 20-30\% of the total infauna biomass in sandy beaches (Dörjes et al., 1986). A. marina is not commercially important, but they are ecologically important organisms in benthic food webs and they be used as a biomarker for the Nordic area since there are indications that they may ingest plastic particles in the coastal areas from the Nordic area (preliminary data from Haave, 2016). On a global level, wild Arenicola marina populations have also been found to contain microplastics (Van Cauwenberghe et al., 2015), but it is unknown whether environmental exposure to plastics can have direct effects on wild populations, despite seeing effects from laboratory by microplastic exposure (see section 2.4). 
A recent study by Näkki et al. (2017) from the northern Baltic Sea, found that sediment dwelling organisms contribute to mixing of microplastics into deeper layers of the sediment from the top layer. Therefore, it is important to not only focus on the top layers when monitoring for microplastics in sediment, since they are found in sediment dwelling organisms at a depth of 1.7-5.1 cm below the surface (Näkki et al., 2017). 



\section{Food safety}

Abstract: From a food safety perspective, the presence of microplastics in products sold for consumption raises concern for human dietary exposure. Microplastics have been found in fish and shellfish sold for human consumption, some of them, such as blue mussels, are consumed whole. Consuming food items contaminated by microplastics may facilitate the transfer of plastics-associated chemicals to humans. Current expert reviews suggest that microplastics in fish and shellfish pose negligible risk to human health. However, there are still a lot of uncertainties around plastic and food-safety, for example are the effects of nanoplastics still unknown.

The presence of microplastics in products available for consumption by humans raises dietary concerns. Microplastics have been reported in beer and honey (Liebezeit \& Liebezeit, 2014), as well as in table salt (Yang et al., 2015; Karami et al., 2017), but most reports focus on microplastic presence in seafood (EFSA, 2016; FAO, 2017).

\subsection{Microplastics in fish}

Fish captures for human consumption have be found to contain microplastics, as any species of fish from the Pacific, Atlantic and Indian ocean, and the Mediterranean Sea had individuals with microplastics in their digestive tracts (section 2.4). In addition, fish from the Nordic marine environment have also been found to contain macro and microplastic (see section 4). It is important to note that microplastics have only been identified in the gastrointestinal tract of fish. Most fish are gutted before consumption, removing the microplastics that renders the exposure of humans to microplastics through ingesting fish negligible. However, small pelagic fish, such as sardines and anchovies are consumed whole, without the removal of the digestive system. Microplastics have been observed in few species of small marine pelagic species, for example the Pacific anchovy (Engraulis japonicas) (Rochman et al., 2015).

\subsection{Microplastics in shellfish and crustaceans}

From section 2.4, microplastics have been found in both wild and commercial blue mussels. For blue mussels and human consumption from the Nordic environment, almost nothing is known at this point, regarding microplastic content in mussels for human consumption. 
As discussed in section 2.4.2, microplastics have been identified in crustaceans, but only in snow crab from the Nordic marine area. When crustaceans are prepared, peeling removes most of the digestive tract, the head, gills and shell leaving the abdominal tissue as the edible part. No microplastics have been identified in the edible fraction of shrimps (Devriese et al., 2015). The head gill and digestive tract contain much of the microplastics, However, as the digestive tract is generally removed before consumption, microplastics in the guts present a limited threat to human health (Devriese et al., 2015).

\subsection{Uptake of microplastics into humans from food}

The ability of microplastics to adsorb PBT substances has generated considerable concern that microplastics will transfer potentially hazardous PBTs to marine animals, and may subsequently transfer to humans (e.g. Gouin et al., 2011; Koelmans et al., 2014; Koelmans et al., 2013; Bakir et al., 2012). Most expert reviews agree that most plastic contaminated fish pose negligible risk to human health regarding PBT substances, as the plastic typically resides in the intestines, rather than muscle flesh, but there are uncertainties about the effects of nanosized plastics, which could potentially be able to translocate between (e.g. Brennecke et al., 2015b; EFSA, 2016; Koelmans et al., 2016; Lohmann 2017). However, it is also found microplastic contamination in food that are consumed directly/whole such as shellfish, table salt and honey (and many others may follow with increased research and monitoring). How a long-term exposure to such sources may affect human health, is currently not known. 


\section{Main knowledge gaps on plastics within Nordic Marine biota}

Abstract: There are several large knowledge gaps regarding the ingestion of microplastics in Nordic marine biota, both geographically but also regarding different phyla of biota investigated. Few studies have been carried out in Skagerrak, Kattegat, and north in the Nordic marine environment. There are also very few studies from the sea areas west and north of the Faroe Islands, including areas around Iceland and Greenland. It is a need to study microplastic ingestion in same species with comparable methods for different areas to investigate spatial trends.

There are several large knowledge gaps regarding ingestion in Nordic marine biota, both geographically but also regarding phyla of biota investigated.

The most studied areas are the North Sea and the Baltic Sea, with few studies in Skagerrak, Kattegat and northern Norway. There are also no studies from the sea area close to Greenland, Table 11.

Table 11: Plastic ingestion studies from the different sea areas defined as "Nordic marine environment" in this report

\begin{tabular}{lcc} 
Sea area & No of studies fish & No of studies invertebrates \\
\hline Baltic Sea & 5 & 2 \\
North Sea & 4 & 1 \\
Skagerrak & 1 & 0 \\
Kattegat & 2 & 1 \\
Coast of Greenland & 0 & 0 \\
Coastal Svalbard & 0 & 1 \\
Coastal sea areas north and east of Varangerhalvøya & 1 & 1 \\
\hline
\end{tabular}

There are many knowledge gaps regarding ingestion in Nordic marine biota, and Table 12 shows the breadth of phyla in the marine environment studied, with examples of available information in the Nordic environment regarding plastic ingestion.

Due to OSPAR, seabirds form the Nordic marine environment are used to monitor plastics down to $1 \mathrm{~mm}$ in size, see section 4.2. However, data on microplastics smaller than $1 \mathrm{~mm}$ in sea birds is lacking from the Nordic marine environment, and therefore it is recommended that there should be a focus to investigate smaller plastic particles in seabirds preying from the sea.

For fish, there are some information on pelagic and demersal fish species, but there is not a broad understanding of plastic ingestion in fish from the Nordic environment concerning levels and effects. There is a need to increase the data ground for the 
different fish species, and using standardised methods, so it is possible to compare levels between studies. There is also no information on smaller developmental stages of fish and invertebrates. If larvae are interacting with plastics, or ingesting microplastics, it may affect development and have ultimate consequences on populations.

Currently there is no information on phytoplankton or zooplankton on ingestion or other interaction with microplastics from the Nordic marine environment. The only study showing in situ uptake of plastics in copepods and krill is from the North Pacific (Desforges et al., 2015). It is important to study these organisms from lower trophic level organisms because of their position in the food wed, for example zooplankton and phytoplankton.

Pelagic cnidarians, in the case of jellyfish, have not yet been studied for microplastic ingestion from the Nordic environment, or even globally. However, it has been hypothesised by laboratory studies that they can accumulate nanoplastics (Patwa et al., 2015). In addition, no studies have investigated cnidarians in general, e.g. sponges or corals but there are suggestions that corals can take in particles (Hall et al., 2015). Corals are highly diverse phyla that can be found in coastal and offshore areas as well as in deep fjords. Since they are filtering water and lying close to the seabed these could be indicators of plastics deposition in deep waters.

Since a lot of the microplastics found in marine environments are in the sediments, it is important to study sediment dwelling organisms. Very little information is available on e.g. marine worms, only a few preliminary studies are conducted in Arenicola marina from the Bergen city harbour. For the arthropods, there is just one observation of plastic ingestion in Snow-crab from the coastal areas near Varangerhalvøya, so there is a need to know more on crustaceans as a whole. For the bivalves in general, there are some (none-peer reviewed) studies on blue mussels, but more information on blue mussels are required since they can be useful as biomonitors. In addition to the blue mussels, there are many other important bivalve species that have different feeding mechanisms, and therefore can contribute with a broader information on plastic exposure to this group. In addition, nothing has yet been evaluated on gastropods in coastal area, cephalopods or deep diving species that are prey for many marine mammals.

In addition, there are insufficient knowledge on uptake of microplastics in marine mammals available from the Nordic marine environment. Since they are at the top of the food chain these could be indicators of trophic transfer and possible bioaccumulation. 
Table 12: Number of studies on microplastics presence in marine phyla from the Nordic marine area

\begin{tabular}{|c|c|c|}
\hline Phyla & Examples & Number of studies \\
\hline Bacteria & Cyanobacteria & NONE \\
\hline \multirow[t]{2}{*}{ Protophyta Protozoa } & $\begin{array}{l}\text { Dinoflagellates, diatoms, Radiolarians, } \\
\text { foraminifera }\end{array}$ & NONE \\
\hline & Moulds Lichens & NONE \\
\hline Chlorophytes & Green algae, Brown algae, Red algae & NONE \\
\hline \multicolumn{3}{|l|}{ Phaeophyta } \\
\hline \multicolumn{3}{|l|}{ Rhodophyta } \\
\hline \multicolumn{3}{|l|}{ Anthrophyta } \\
\hline Porifera & Sponges & NONE \\
\hline Cnidarians & Hydrozoans, true jellyfish, comb jellies sea & NONE \\
\hline Ctenophores & anemones and corals & \\
\hline Platyhelminthes & Planarians, tapeworms, ribbon worms & NONE \\
\hline \multicolumn{3}{|l|}{ Nemertea } \\
\hline Nematodes & Roundworms ribbon worms & NONE \\
\hline \multicolumn{3}{|l|}{ Priapulida } \\
\hline \multirow[t]{5}{*}{ Mollusca } & Polyplacophora: chitons & Mytilus sp. \\
\hline & Scaphopoda: tusk shells & Cockles \\
\hline & Gastropods: snails and nudibranchs & \\
\hline & Bivalves: clams, mussels, oysters & NO OTHER SPECIES \\
\hline & Cephalopods: octopus, squid etc. & \\
\hline Annelida & Polychaete marine worms & Arenicola marina \\
\hline \multirow[t]{3}{*}{ Arthropoda } & Crustaceans: crabs, lobsters etc. & Snow crab \\
\hline & Horseshoe crabs, sea spiders & NO OTHER SPECIES \\
\hline & Insects & \\
\hline Pogonophora & Riftia worms & NONE \\
\hline brachipoda & Lampshells & \\
\hline echiura & Spoon worms & \\
\hline sipunculdia & Peanut worms & \\
\hline \multirow[t]{2}{*}{ Echinodermata } & Crinoidea, Echinoidea, Asteroidea & NONE \\
\hline & Ophiuroidea, Holothuroidea & \\
\hline Chordata: vertebrata & Fish & SOME \\
\hline Chordata: vertebrata & Sea birds & MOST \\
\hline \multirow[t]{2}{*}{ Chordata: vertebrata } & Mammals & Ziphus sp. \\
\hline & & SOME OTHER SPECIES \\
\hline
\end{tabular}





\section{Conclusion}

Biota from the Nordic marine environment are interacting with plastic pollution, both through physical impact such as entanglement and through ingestion. Ingestion has been found in a high number of seabirds and several stranded mammals are found to contain large volumes of plastics in their digestive system. Ingestion of plastics has been documented in 14 fish species, which many of them are of ecology and commercially importance. A total of 5,241 fish individuals has been investigated for microplastic ingestion from nine different studies. Microplastics have been identified in blue mussels, but this has only been investigated in a total of 205 individuals from six studies. Preliminary studies found synthetic fibres in marine worms and in faeces of brittle stars and in Snow crabs. Comparability between and within studies of plastic ingestion by biota from the Nordic environment and other regions are difficult as there are: 1) limited number of studies, 2) limited number of studies on the same species from different location and, 3) different methods used. Most studies have been on Atlantic cod and Herring, with the Baltic Sea and the North Sea as the most studied areas. Few studies have been carried out in Skagerrak, Kattegat, and north in the Nordic marine environment. There are also very few studies from the sea areas west and north of the Faroe Islands, including areas around Iceland and Greenland.

It is important that future research is directed towards the knowledge gaps highlighted in this report, to acquire a better understanding on plastic ingestion and impact on biota from the Nordic marine environment. 



\section{References}

Agersnap, S. (2013). Mikroplastik i havmiljøet-Metode til kvantificering af mikroplastik i havvand, blåmusling og fisk. Aarhus, Denmark.

Andrady, A.L. (2011). Microplastics in the marine environment. Marine Pollution Bulletin, 62(8), pp.1596-1605. https://doi.org/10.1016/j.marpolbul.2011.05.030

Andrady, A.L. (2015). Persistence of Plastic Litter in the Oceans. In M. Bergmann, L. Gutow, \& M. Klages, eds. Marine Anthropogenic Litter. Springer, Cham, Switzerland, pp. 57-72. https://doi.org/10.1007/978-3-319-16510-3_3

Andrady, A.L. \& Neal, M.A. (2009). Applications and societal benefits of plastics. Philosophical transactions of the Royal Society of London. Series B, Biological sciences, 364(1526), pp.1977-84. https://doi.org/10.1098/rstb.2008.0304

Arthur, C., Baker, J. \& Bamford, H., (2009). Proceedings of the International Research Workshop on the Occurrence, Effects, and Fate of Microplastic Marine Debris. Group, p.53o.

Au, S.Y., Bruce, T.F., Bridges, W.C. \& Klaine, S.J. (2015). Responses of Hyalella azteca to acute and chronic microplastic exposures. Environmental Toxicology and Chemistry, 34(11), pp.25642572. https://doi.org/10.1002/etc.3093

Avio, C.G., Gorbi, S. \& Regoli, F. (2015a). Experimental development of a new protocol for extraction and characterization of microplastics in fish tissues: First observations in commercial species from Adriatic Sea. Marine Environmental Research, 111, pp.18-26. https://doi.org/10.1016/j.marenvres.2015.06.014

Avio, C.G., Gorbi, S. \& Regoli, F. (2015b). Experimental development of a new protocol for extraction and characterization of microplastics in fish tissues: First observations in commercial species from Adriatic Sea. Marine Environmental Research, 111, pp.18-26. https://doi.org/10.1016/j.marenvres.2015.06.014

Bakir, A., Rowland, S.J. \& Thompson, R.C. (2012). Competitive sorption of persistent organic pollutants onto microplastics in the marine environment. Marine pollution bulletin, 64(12), pp.2782-9. https://doi.org/10.1016/j.marpolbul.2012.09.010

Barnes, D.K.A., Galgani, F., Thompson, R.C. \& Barlaz, M. (2009). Accumulation and fragmentation of plastic debris in global environments. Philosophical transactions of the Royal Society of London. Series B, Biological sciences, 364(1526), pp.1985-98.

https://doi.org/10.1098/rstb.2008.0205

Barnes, D.K.A. \& Milner, P. (2005). Drifting plastic and its consequences for sessile organism dispersal in the Atlantic Ocean. Marine Biology, 146(4), pp.815-825.

https://doi.org/10.1007/s00227-004-1474-8

Batel, A., Linti, F., Scherer, M., Erdinger, L. \& Braunbeck, T. (2016). The transfer of benzo[a]pyrene from microplastics to Artemia nauplii and further to zebrafish via a trophic food web experiment $-C Y P_{1} A$ induction and visual tracking of persistent organic pollutants. Environmental toxicology and chemistry / SETAC. https://doi.org/10.1002/etc.3361

Baulch, S. \& Perry, C. (2014). Evaluating the impacts of marine debris on cetaceans. Marine pollution bulletin, 8o(1-2), pp.210-21. https://doi.org/10.1016/j.marpolbul.2013.12.050

Beer, S. (2016). Microplastic Ingestion by two Baltic Key Species Herring and Sprat, Seasonal and Dedacal Trends. Denmark. Master thesis.

Bergmann, M. \& Klages, M. (2012). Increase of litter at the Arctic deep-sea observatory HAUSGARTEN. Marine Pollution Bulletin, 64(12), pp. 2734-2741.

https://doi.org/10.1016/j.marpolbul.2012.09.018 
Bergmann, M., Peeken, I., Beyer, B., Krumpen, T., Primpke, S., Tekman, M.B. \& Gerdts, G. (2017). Vast Quantities of Microplastics in Arctic Sea Ice-A Prime Temporary Sink for Plastic Litter and a Medium of Transport. In Fate and Impact of Microplastics in Marine Ecosystems. MICRO 2016, Amsterdam, Elsevier, pp. 75-76. https://doi.org/10.1016/B978-0-12-8122716.00073-9

Besseling, E., Foekema, E.M., Van Franeker, J.A., Leopold, M.F., Kühn, S., Bravo Rebolledo, E.L., Heße, E., Mielke, L., IJzer, J., Kamminga, P. \& Koelmans, A.A. (2015). Microplastic in a macro filter feeder: Humpback whale Megaptera novaeangliae. Marine pollution bulletin, 95 (1), pp. 248-252. https://doi.org/10.1016/j.marpolbul.2015.04.007

Besseling, E., Wegner, A., Foekema, E.M., van den Heuvel-Greve, M.J. \& Koelmans, A.A. (2013). Effects of microplastic on fitness and PCB bioaccumulation by the lugworm Arenicola marina (L.). Environmental science \& technology, 47(1), pp.593-60o. https://doi.org/10.1021/es302763x

Bilyard, G.R. (1987). The value of benthic infauna in marine pollution monitoring studies. Marine Pollution Bulletin, 18(11), pp.581-585. https://doi.org/10.1016/0025-326X(87)90277-3

Boerger, C.M., Lattin, G.L., Moore, S.L. \& Moore, C.J. (2010). Plastic ingestion by planktivorous fishes in the North Pacific Central Gyre. Marine Pollution Bulletin, 60, pp.2275-2278. https://doi.org/10.1016/j.marpolbul.2010.08.007

Bottolfsen, T. (2016). Microplastics in river sediments, Norway: Evaluation of a recent technique for the detection of microplastic particles. Oslo (NMBU/NIVA) Master thesis.

Brennecke, D., Ferreira, E.C., Costa, T.M.M., Appel, D., da Gama, B.A.P. \& Lenz, M. (2015). Ingested microplastics $(>100 \mu \mathrm{m})$ are translocated to organs of the tropical fiddler crab Uca rapax. Marine Pollution Bulletin, 96, pp. 491-495. https://doi.org/10.1016/j.marpolbul.2015.05.001

Browne, M.A., Dissanayake, A., Galloway, T.S., Lowe, D.M. \& Thompson, R.C. (2008). Ingested Microscopic Plastic Translocates to the Circulatory System of the Mussel, Mytilus edulis (L.). Environmental Science \& Technology, 42(13), pp.5026-5031. https://doi.org/10.1021/es800249a

Bråte, I.L.N., Eidsvoll, D.P. \& Steindal, Calin Constantin Thomas, K. V. (2016). Plastic ingestion by Atlantic cod (Gadus morhua) from the coast of Norway. Marine pollution bulletin, 112, pp.105-110. https://doi.org/10.1016/j.marpolbul.2016.08.034

Carr, S.A., Liu, J. \& Tesoro, A.G. (2016). Transport and fate of microplastic particles in wastewater treatment plants. Water Research, 91, pp.174-182.

https://doi.org/10.1016/j.watres.2016.01.002

Van Cauwenberghe, L., Claessens, M., Vandegehuchte, M.B. \& Janssen, C.R. (2015). Microplastics are taken up by mussels (Mytilus edulis) and lugworms (Arenicola marina) living in natural habitats. Environmental Pollution, 199, pp.10-17.

https://doi.org/10.1016/j.envpol.2015.01.008

Van Cauwenberghe, L. \& Janssen, C.R. (2014). Microplastics in bivalves cultured for human consumption. Environmental pollution (Barking, Essex: 1987), 193, pp.65-70. https://doi.org/10.1016/j.envpol.2014.06.010

Cedervall, T., Hansson, L.-A., Lard, M., Frohm, B., Linse, S. \& Thulin, E. (2012). Food Chain Transport of Nanoparticles Affects Behaviour and Fat Metabolism in Fish. PLoS ONE, 7(2), p.e32254. https://doi.org/10.1371/journal.pone.0032254

Cole, M., Lindeque, P., Halsband, C. \& Galloway, T.S. (2011). Microplastics as contaminants in the marine environment: a review. Marine Pollution Bulletin, 62, pp.2588-97.

https://doi.org/10.1016/j.marpolbul.2011.09.025

Collard, F., Gilbert, B., Eppe, G., Parmentier, E. \& Das, K. (2015). Detection of Anthropogenic Particles in Fish Stomachs: An Isolation Method Adapted to Identification by Raman Spectroscopy. Archives of Environmental Contamination and Toxicology, 69(3), pp.331-9. https://doi.org/10.1007/s00244-015-0221-0

Connon, R.E., Geist, J. \& Werner, I. (2012). Effect-based tools for monitoring and predicting the ecotoxicological effects of chemicals in the aquatic environment. Sensors, 12(9), pp.12741-71. https://doi.org/10.3390/s120912741 
Cózar, A., Martí, E., Duarte, C.M., García-de-Lomas, J., van Sebille, E., Ballatore, T.J., Eguíluz, V.M., González-Gordillo, J.I., Pedrotti, M.L., Echevarría, F., Troublè, R. \& Irigoien, X., 2017. The Arctic Ocean as a dead end for floating plastics in the North Atlantic branch of the Thermohaline Circulation. Science Advances, 3(4), pp.1-8.

https://doi.org/10.1126/sciadv.1600582

Day, R.H., Wehle, D.H.S. \& Coleman, F.C. (1985). Ingestion of plastic pollutants by marine birds. In: Shomura, R. S., Yoshida, H. o. (ed.) Proc. Workshop on the Fate and Impact of Marine Debris, 27-29 November 1984, Honolulu, Hawaii. U.S. Dept. Commerce, NOAA Techn. Memo.

Dehaut, A., Cassone, A.-L., Frère, L., Hermabessiere, L., Himber, C., Rinnert, E., Rivière, G., Lambert, C., Soudant, P., Huvet, A., Duflos, G. \& Paul-Pont, I. (2016). Microplastics in seafood: Benchmark protocol for their extraction and characterization. Environmental pollution (Barking, Essex: 1987), 215, pp.223-33. https://doi.org/10.1016/j.envpol.2016.05.018

Devriese, L.I., van der Meulen, M.D., Maes, T., Bekaert, K., Paul-Pont, I., Frère, L., Robbens, J. \& Vethaak, A.D. (2015). Microplastic contamination in brown shrimp (Crangon crangon, Linnaeus 1758) from coastal waters of the Southern North Sea and Channel area. Marine Pollution Bulletin, 98(1-2), pp.179-187. https://doi.org/10.1016/j.marpolbul.2015.06.051

Doyle, M.J., Watson, W., Bowlin, N.M. \& Sheavly, S.B. (2011). Plastic particles in coastal pelagic ecosystems of the Northeast Pacific Ocean. Marine environmental research, 71(1), pp.41-52. https://doi.org/10.1016/j.marenvres.2010.10.001

Dörjes, J., Michaelis, H. \& Rhode, B. (1986). Long-term studies of macrozoobenthos in intertidal and shallow subtidal habitats near the island of Norderney (East Frisian coast, Germany). Hydrobiologia, 142(1), pp.217-232. https://doi.org/10.1007/BFooo26761

Daan, N. (1973). A quantitative analysis of the food intake of North Sea cod, Gadus Morhua. Netherlands Journal of Sea Research, 6(4), pp.479-517. https://doi.org/10.1016/00777579(73)90002-1

EFSA (2016). Presence of microplastics and nanoplastics in food, with particular focus on seafood. EFSA Journal, 14(6).

Eriksen, E. (2014). Survey report from the joint Norwegian/Russian ecosystem survey in the Barents Sea and adjacent waters, IMR/PINRO Joint Report Series, No. 1/2015, 153 pp.

Eriksson, C. \& Burton, H. (2003). Origins and Biological Accumulation of Small Plastic Particles in Fur Seals from Macquarie Island. AMBIO: A Journal of the Human Environment, 32(6), pp.38o-384. https://doi.org/10.1579/0044-7447-32.6.380

FAO (2017). Microplastics in fisheries and aquaculture: status of knowledge on their occurrence and implications for aquatic organisms and food safety. In A. Lusher, P. Hollman, \& J. Mendoza-Hall, eds.

Farrell, P. \& Nelson, K. (2013). Trophic level transfer of microplastic: Mytilus edulis (L.) to Carcinus maenas (L.). Environmental Pollution, 177, pp.1-3.

https://doi.org/10.1016/j.envpol.2013.01.046

Foekema, E.M., De Gruijter, C., Mergia, M.T., van Franeker, J.A., Murk, A.J. \& Koelmans, A.A. (2013). Plastic in North Sea fish. Environmental science \& technology, 47(15), pp.8818-24. https://doi.org/10.1021/es400931b

van Franeker, J.A. (1985). Plastic ingestion in the North Atlantic fulmar. Marine Pollution Bulletin, 16(9), pp.367-369. https://doi.org/10.1016/0025-326X(85)9009o-6

van Franeker, J.A., Blaize, C., Danielsen, J., Fairclough, K., Gollan, J., Guse, N., Hansen, P.-L., Heubeck, M., Jensen, J.-K., Le Guillou, G., Olsen, B., Olsen, K.-O., Pedersen, J., Stienen, E.W.M. \& Turner, D.M. (2011). Monitoring plastic ingestion by the northern fulmar Fulmarus glacialis in the North Sea. Environmental pollution, 159(10), pp.2609-15. https://doi.org/10.1016/j.envpol.2011.06.008

Van Franeker, J.A. \& Law, K.L. (2015). Seabirds, gyres and global trends in plastic pollution. Environmental Pollution, 203, pp.89-96. https://doi.org/10.1016/j.envpol.2015.02.034

Galgani, F., Hanke, G. \& Thomas, M. (2015). Global Distribution, Composition and Abundance of Marine Litter. In M. Bergmann, L. Klages, \& M. Gutow, eds. Book Marine Anthropogenic Litter. p. 447. https://doi.org/10.1007/978-3-319-16510-3_2 
GESAMP (2015). Sources, fate and effects of microplastics in the marine environment: a global assessment. Kershaw, P. J., ed. Rep. Stud. GESAMP No. 90, 96 p.,

GESAMP (2016). Sources, fate and effects of microplastics in the marine environment: part two of a global assessment. In: Kershaw, P.J., Rochman, C.M. (Eds.). Rep. Stud. GESAMP No. 93, 220 p.,

Van Gestel, C.A.M. \& Van Brummelen, T.C. (1996). Incorporation of the biomarker concept in ecotoxicology calls for a redefinition of terms. Ecotoxicology, 5(4), pp.217-225. https://doi.org/10.1007/BFo0118992

Gewert, B., Ogonowski, M., Barth, A. \& MacLeod, M. (2017). Abundance and composition of near surface microplastics and plastic debris in the Stockholm Archipelago, Baltic Sea. Marine Pollution Bulletin. In press. https://doi.org/10.1016/j.marpolbul.2017.04.062

Gewert, B., Plassmann, M.M. \& MacLeod, M. (2015). Pathways for degradation of plastic polymers floating in the marine environment. Environmental science. Processes \& impacts, 17(9), pp.1513-21. https://doi.org/10.1039/C5EMoo207A

Goldstein, M.C., Titmus, A.J., Ford, M., Inman, B. \& Keen, E. (2013). Scales of Spatial Heterogeneity of Plastic Marine Debris in the Northeast Pacific Ocean J. Hewitt, ed. PLoS $O N E, 8(11)$, p.e8oo2o. https://doi.org/10.1371/journal.pone.0080020

Gouin, T., Roche, N., Lohmann, R. \& Hodges, G. (2011). A thermodynamic approach for assessing the environmental exposure of chemicals absorbed to microplastic. Environmental science \& technology, 45(4), pp.1466-72. https://doi.org/10.1021/es1032025

Green, D.S., Boots, B., Blockley, D.J., Rocha, C. \& Thompson, R. (2015). Impacts of Discarded Plastic Bags on Marine Assemblages and Ecosystem Functioning. Environmental Science \& Technology, 49(9), pp.5380-5389. https://doi.org/10.1021/acs.est.5boo277

Green, D.S., Boots, B., Sigwart, J., Jiang, S. \& Rocha, C. (2016). Effects of conventional and biodegradable microplastics on a marine ecosystem engineer (Arenicola marina) and sediment nutrient cycling. Environmental Pollution, 208, pp.426-434. https://doi.org/10.1016/j.envpol.2015.10.010

GRID-Arendal (2016). Marine Litter Vital Graphics. Available at: http://old.grida.no/graphicslib/detail/plasticized-animal-species-ingestion_1309

Grigorakis, S., Mason, S.A. \& Drouillard, K.G. (2017). Determination of the gut retention of plastic microbeads and microfibers in goldfish (Carassius auratus). Chemosphere, $169, \mathrm{pp}$ 233-238. https://doi.org/10.1016/j.chemosphere.2016.11.055

Gustafsson, L. (2016). En undersökning om förekomsten av mikroplast i västsvenska blåmusslor (Mytilus edulis). Available at: https://issuu.com/cillidill/docs/en_unders_kning_om_f__rekomsten_av. Master thesis.

Güven, O., Gökdağ, K., Jovanović, B. \& Kıdeyş, A.E. (2017). Microplastic litter composition of the Turkish territorial waters of the Mediterranean Sea, and its occurrence in the gastrointestinal tract of fish. Environmental Pollution, 223, pp.286-294. https://doi.org/10.1016/j.envpol.2017.01.025

Hall, N.M., Berry, K.L.E., Rintoul, L \& Hoogenboom, M.O. (2015). Microplastic ingestion by scleractinian corals. Marine Biology, 162(3), pp 725-732. https://doi.org/10.1007/s00227-0152619-7

Hanke, G., F. Galgani, F., S. Werner, S., Oosterbaan, L., Nilsson, P., Fleet, D. et al. (2013). MSFD GES technical subgroup on marine litter. Guidance on monitoring of marine litter in European Seas. Luxembourg: Joint Research Centre-Institute for Environment and Sustainability, Publications Office of the European Union.

Hannam, M.L., Hagger, J.A., Jones, M.B. \& Galloway, T.S. (2008). Characterisation of esterases as potential biomarkers of pesticide exposure in the lugworm Arenicola marina (Annelida: Polychaeta). Environmental Pollution, 152(2), pp.342-350. https://doi.org/10.1016/j.envpol.2007.06.022

Harper, P. \& Fowler, J. (1987). Plastic pellets in New Zealand storm-killed prions (Pachyptila spp.) 1958-1977. Notornis, 34(1), pp 65-70. 
Hartmann, N.B., Rist, S., Bodin, J., Jensen, L.H., Schmidt, S.N., Mayer, P., Meibom, A. \& Baun, A. (2017). Microplastics as vectors for environmental contaminants: Exploring sorption, desorption, and transfer to biota. Integrated Environmental Assessment and Management, 13(3), pp.488-493. https://doi.org/10.1002/ieam.1904

Hartwig, E., Clemens, T. \& Heckroth, M. (2007). Plastic debris as nesting material in a Kittiwake(Rissa tridactyla)-colony at the Jammerbugt, Northwest Denmark. Marine Pollution Bulletin, 54(5), pp.595-597. https://doi.org/10.1016/j.marpolbul.2007.01.027

Hidalgo-Ruz, V., Gutow, L., Thompson, R.C. \& Thiel, M. (2012). Microplastics in the Marine Environment: A Review of the Methods Used for Identification and Quantification. Environmental Science \& Technology, 46(6), pp.306o-3075. https://doi.org/10.1021/es2031505

Hong, S., Lee, J., Kang, D., Choi, H.-W. \& Ko, S.-H. (2014). Quantities, composition, and sources of beach debris in Korea from the results of nationwide monitoring. Marine Pollution Bulletin, 84(1-2), pp.27-34. https://doi.org/10.1016/j.marpolbul.2014.05.051

Huwer, B., Neuenfeldt, S., Rindorf, A., Andreasen, H., S.-E., L., Storr-Paulsen, M. et al. (2014). Study on stomach content of fish to support the assessment of good environmental status of marine food webs and the prediction of MSY after stock restoration, Final report for EU contract No MARE/2012/02. $56 \mathrm{pp}$

Haave, M., Klunderud, T. \& Goksøyr, A. (2016). Source to sink: Microplastics ingested by benthic fauna from discharge points to deep basins in an urban model fjord. In MICRO2016 abstract. p. 2.

ICES (2017). Interim Report of the International Bottom Trawl Survey Working Group. IBTSWG Report 2017 27-31 March 2017. ICES CM 2017/SSGIEOM:01. 337 pp.

Jambeck, J.R., Geyer, R., Wilcox, C., Siegler, T.R., Perryman, M., Andrady, A., Narayan, R. \& Law, K.L. (2015). Plastic waste inputs from land into the ocean. Science, 347(6223), pp.768-771. https://doi.org/10.1126/science.1260352

Johansson A. (2011). Mikroskopiska antropogena partiklar i marina sediment. Göteborgs universitet, p. 37.

Johnsen, H.R. \& Busch, K.E.T. (2017). "Fishing for Litter" as a measure against marine litter in Norway. Norwegian Environment Agency Report.

Karami, A., Golieskardi, A., Keong Choo, C., Larat, V., Galloway, T.S. \& Salamatinia, B. (2017). The presence of microplastics in commercial salts from different countries. Scientific Reports, 7, p.46173. https://doi.org/10.1038/srep46173

Kiessling, T., Gutow, L. \& Thiel, M. (2015). Marine Litter as Habitat and Dispersal Vector. In Marine Anthropogenic Litter. Cham: Springer International Publishing, pp. 141-181.

https://doi.org/10.1007/978-3-319-16510-3_6

Koelmans, A.A., Bakir, A., Burton, G.A. \& Janssen, C.R. (2016). Microplastic as a Vector for Chemicals in the Aquatic Environment: Critical Review and Model-Supported Reinterpretation of Empirical Studies. Environmental science \& technology, 50(7), pp.3315-26. https://doi.org/10.1021/acs.est.5bo6o69

Koelmans, A.A., Besseling, E. \& Foekema, E.M. (2014). Leaching of plastic additives to marine organisms. Environmental Pollution, 187, pp.49-54.

https://doi.org/10.1016/j.envpol.2013.12.013

Koelmans, A.A., Besseling, E., Wegner, A. \& Foekema, E.M. (2013). Plastic as a carrier of POPs to aquatic organisms: a model analysis. Environmental science \& technology, 47(14), pp.7812-20. https://doi.org/10.1021/es40116gn

Kwon, B.G., Koizumi, K., Chung, S.-Y., Kodera, Y., Kim, J.-O. \& Saido, K. (2015). Global styrene oligomers monitoring as new chemical contamination from polystyrene plastic marine pollution. Journal of Hazardous Materials, 300, pp.359-367.

https://doi.org/10.1016/j.jhazmat.2015.07.039

Kühn, S., Bravo Rebolledo, E. \& van Franeker, J.A. (2015). Deleterious. Effects of Litter on Marine Life. In M. Bergmann, L. Gutow, \& M. Klages, eds. Marine Anthropogenic Litter. Springer, pp. 75-116. https://doi.org/10.1007/978-3-319-16510-3_4 
Kühn, S. \& van Franeker, J.A. (2012). Plastic ingestion by the northern fulmar (Fulmarus glacialis) in Iceland. Marine Pollution Bulletin, 64. pp. 1252-1254.

https://doi.org/10.1016/j.marpolbul.2012.02.027

Kühn, S., Van Werven, B., Van Oyen, A., Meijboom, A., Bravo Rebolledo, E.L. \& Van Franeker, J.A. (2016). The use of potassium hydroxide $(\mathrm{KOH})$ solution as a suitable approach to isolate plastics ingested by marine organisms. Marine Pollution Bulletin, 115, pp 86-90.

https://doi.org/10.1016/j.marpolbul.2016.11.034

Lambert, S., Scherer, C. \& Wagner, M. (2017). Ecotoxicity testing of microplastics: Considering the heterogeneity of physicochemical properties. Integrated Environmental Assessment and Management, 13(3), pp.470-475. https://doi.org/10.1002/ieam.1901

Lambert, S., Sinclair, C. \& Boxall, A. (2014). Occurrence, degradation, and effect of polymerbased materials in the environment. Reviews of environmental contamination and toxicology, 227, pp.1-53. https://doi.org/10.1007/978-3-319-01327-5_1

Lambert, S. \& Wagner, M. (2016). Characterisation of nanoplastics during the degradation of polystyrene. Chemosphere, 145, pp.265-8. https://doi.org/10.1016/j.chemosphere.2015.11.078

Lambertsen, R.H. \& Kohn, B.A. (1987). Unusual Multisystemic Pathology in a Sperm Whale Bull. Journal of Wildlife Diseases, 23(3), pp.510-514. https://doi.org/10.7589/0090-3558-23.3.510

Lassen, C., Hansen, S. F., Magnusson, K., Hartmann, N. B., Rehne Jensen, P., Nielsen, T. G., \& Brinch, A. (2015). Microplastics: Occurrence, effects and sources of releases to the environment in Denmark. Copenhagen K: Danish Environmental Protection Agency

Law, K.L., Moret-Ferguson, S., Maximenko, N.A., Proskurowski, G., Peacock, E.E., Hafner, J. \& Reddy, C.M. (2010). Plastic Accumulation in the North Atlantic Subtropical Gyre. Science, 329(5996), pp.1185-1188. https://doi.org/10.1126/science.1192321

Leclerc, L.-M.E., Lydersen, C., Haug, T., Bachmann, L., Fisk, A.T. \& Kovacs, K.M. (2012). A missing piece in the Arctic food web puzzle? Stomach contents of Greenland sharks sampled in Svalbard, Norway. Polar Biology, 35(8), pp.1197-1208. https://doi.org/10.1007/s00300-0121166-7

Lenz, R., Enders, K., Beer, S., Sørensen, T.K. \& Stedmon, C.A. (2015). Analysis of microplastic in the stomachs of herring and cod from the North Sea and Baltic Sea. DTU Aqua National Institute of Aquatic Resources report. 29 pages.

Lenz, R., Enders, K., Stedmon, C.A., Mackenzie, D.M.A. \& Nielsen, T.G. (2015). A critical assessment of visual identification of marine microplastic using Raman spectroscopy for analysis improvement. Marine Pollution Bulletin, 100(1), pp.82-91. https://doi.org/10.1016/j.marpolbul.2015.09.026

Li, J., Yang, D., Li, L., Jabeen, K. \& Shi, H. (2015). Microplastics in commercial bivalves from China. Environmental Pollution, 207, pp.190-195. https://doi.org/10.1016/j.envpol.2015.09.018

Liboiron, M., Liboiron, F., Wells, E., Richárd, N., Zahara, A., Mather, C. 5, Bradshaw, H. \& Murichi, J. (2016). Low plastic ingestion rate in Atlantic Cod (Gadus morhua) from Newfoundland destined for human consumption collected through citizen science methods. Marine Pollution Bulletin, 113, pp 428-437. https://doi.org/10.1016/j.marpolbul.2016.10.043

Liebezeit, G. \& Liebezeit, E. (2014). Synthetic particles as contaminants in German beers. Food additives \& contaminants. Part A, Chemistry, analysis, control, exposure \& risk assessment, 31(9), pp.1574-8. https://doi.org/10.1080/19440049.2014.945099

Lohmann, R. (2017). Microplastics are not important for the cycling and bioaccumulation of organic pollutants in the oceans-but should microplastics be considered POPs themselves? Integrated Environmental Assessment and Management, 13(3), pp.460-465. https://doi.org/10.1002/ieam.1914

Lu, Y., Zhang, Y., Deng, Y., Jiang, W., Zhao, Y., Geng, J., Ding, L. \& Ren, H. (2016). Uptake and Accumulation of Polystyrene Microplastics in Zebrafish (Danio rerio) and Toxic Effects in Liver. Environmental Science \& Technology, 50(7), pp.4054-406o. https://doi.org/10.1021/acs.est.6boo183 
Lusher, A. (2015). Microplastics in the Marine Environment: Distribution, Interactions and Effects. In M. Bergmann, L. Gutow, \& M. Klages, eds. Marine Anthropogenic Litter. Springer, Cham, Switzerland, pp. 245-307. https://doi.org/10.1007/978-3-319-16510-3_10

Lusher, A.L., Burke, A., O'Connor, I. \& Officer, R. (2014). Microplastic pollution in the Northeast Atlantic Ocean: Validated and opportunistic sampling. Marine Pollution Bulletin, 88(1), pp.325-333. https://doi.org/10.1016/j.marpolbul.2014.08.023

Lusher, A.L., Hernandez-Milian, G., O’Brien, J., Berrow, S., O'Connor, I. \& Officer, R. (2015). Microplastic and macroplastic ingestion by a deep diving, oceanic cetacean: The True's beaked whale Mesoplodon mirus. Environmental Pollution, 199, pp.185-191. https://doi.org/10.1016/j.envpol.2015.01.023

Lusher, A.L., Tirelli, V., O'Connor, I. \& Officer, R. (2015). Microplastics in Arctic polar waters: the first reported values of particles in surface and sub-surface samples. Scientific reports, 5, p.14947. https://doi.org/10.1038/srep14947

Lusher, A.L., Welden, N.A., Sobral, P., Cole, M., Blackford, J., Lewis, C., Lenton, T.M., Galloway, T.S., Robbens, J., Huvet, A., Zambonino-Infante, J., Paul-Pont, I., Huvet, A., Soudant, P. \& Reifferscheid, G. (2017). Sampling, isolating and identifying microplastics ingested by fish and invertebrates. Analytical Methods, 9(9), pp.1346-1360. https://doi.org/10.1039/C6AY02415G

Löder, M.G.J. \& Gerdts, G. (2015). Methodology Used for the Detection and Identification of Microplastics-A Critical Appraisal. In Marine Anthropogenic Litter. Cham: Springer International Publishing, pp. 201-227. https://doi.org/10.1007/978-3-319-16510-3_8

Maes, T., Jessop, R., Wellner, N., Haupt, K. \& Mayes, A.G. (2017). A rapid-screening approach to detect and quantify microplastics based on fluorescent tagging with Nile Red. Scientific Reports, 90, pp.59-73. https://doi.org/10.1038/srep44501

Magnusson, K., Eliasson, K., Fråne, A., Haikonen, K., Hultén, J., Olshammar, M., Stadmark, J., Voisin, A. \& Miljöinstitutet, S. (2016). Swedish sources and pathways for microplastics to the marine environment. Swedish Environmental Protection Agency, Report number: C 183 .

Magnusson, K., Jörundsdóttir, H., Norén, F., Lloyd, H., Talvitie, J. \& Setälä, O. (2016). Microlitter in sewage treatment systems $A$ Nordic perspective on waste water treatment plants as pathways for microscopic anthropogenic particles to marine systems. TemaNord report 2016:510.

Magnusson, K. \& Norén, F. (2011). Mikroskopiskt skräp i havet metodutveckling för miljöövervakning. Naturvårdsverket report.

Magnusson, K. \& Wahlberg, C, F. (2014). Screening of microplastic particles in and down-stream a wastewater treatment plant. IVL Svenska Miljöinstitutet report NR B 2208.

Mahon, A.M., O'Connell, B., Healy, M.G., O'Connor, I., Officer, R., Nash, R. \& Morrison, L. (2017). Microplastics in Sewage Sludge: Effects of Treatment. Environmental Science \& Technology, 51(2), pp.810-818. https://doi.org/10.1021/acs.est.6bo4048

MARLIN (2013). Litter monitoring and raising awareness. Final report of Baltic marine litter project marlin. (http://www.cbss.org/wp-content/uploads/2012/08/marlin-baltic-marine-litterreport.pdf)

Mathalon, A. \& Hill, P. (2014). Microplastic fibers in the intertidal ecosystem surrounding Halifax Harbor, Nova Scotia. Marine pollution bulletin, 81(1), pp.69-79.

https://doi.org/10.1016/j.marpolbul.2014.02.018

Michielssen, M.R., Michielssen, E.R., Ni, J. \& Duhaime, M.B. (2016). Fate of microplastics and other small anthropogenic litter (SAL) in wastewater treatment plants depends on unit processes employed. Environmental Science: Water Research \& Technology., 2(6), pp.10641073. https://doi.org/10.1039/C6EWoo207B

Miranda, D. de A. \& de Carvalho-Souza, G.F. (2016). Are we eating plastic-ingesting fish? Marine Pollution Bulletin, 103(1-2), pp.109-114. https://doi.org/10.1016/j.marpolbul.2015.12.035

von Moos, N., Burkhardt-Holm, P. \& Köhler, A. (2012). Uptake and effects of microplastics on cells and tissue of the blue mussel Mytilus edulis L. after an experimental exposure.

Environmental science \& technology, 46(20), pp.11327-35. https://doi.org/10.1021/es302332W 
Mordecai, G., Tyler, P.A., Masson, D.G. \& Huvenne, V.A.I. (2011). Litter in submarine canyons off the west coast of Portugal. Deep Sea Research Part II: Topical Studies in Oceanography, 58(23-24), pp.2489-2496. https://doi.org/10.1016/j.dsr2.2011.08.009

Mrosovsky, N., Ryan, G.D. \& James, M.C. (2009). Leatherback turtles: The menace of plastic. Marine Pollution Bulletin, 58(2), pp.287-289. https://doi.org/10.1016/j.marpolbul.2008.10.018

Murray, F. \& Cowie, P.R. (2011). Plastic contamination in the decapod crustacean Nephrops norvegicus (Linnaeus, 1758). Marine Pollution Bulletin, 62, pp.1207-1217. https://doi.org/10.1016/j.marpolbul.2011.03.032

Napper, I.E., Bakir, A., Rowland, S.J. \& Thompson, R.C. (2015). Characterisation, quantity and sorptive properties of microplastics extracted from cosmetics. Marine Pollution Bulletin, 99(1), pp.178-185. https://doi.org/10.1016/j.marpolbul.2015.07.029

Nelms, S., Coombes, C., Foster, L., Galloway, T., Godley, B., Lindeque, P. \& Witt, M. (2017). Marine anthropogenic litter on British beaches: $A$ 10-year nationwide assessment using citizen science data. Science of The Total Environment, 579, pp.1399-1409.

https://doi.org/10.1016/j.scitotenv.2016.11.137

Neves, D., Sobral, P., Ferreira, J.L. \& Pereira, T. (2015). Ingestion of microplastics by commercial fish off the Portuguese coast. Marine Pollution Bulletin, 101(1), pp.119-126.

https://doi.org/10.1016/j.marpolbul.2015.11.008

Nielsen, J., Hedeholm, R.B., Simon, M. \& Steffensen, J.F. (2014). Distribution and feeding ecology of the Greenland shark (Somniosus microcephalus) in Greenland waters. Polar Biology, 37(1), pp.37-46. https://doi.org/10.1007/s00300-013-1408-3

Nizzetto, L., Futter, M. \& Langaas, S. (2016). Are Agricultural Soils Dumps for Microplastics of Urban Origin? Environmental Science \& Technology, 50(20), pp.10777-10779.

https://doi.org/10.1021/acs.est.6bo4140

Norén, F. \& Naustvoll, L.J. (2011). Survey of microscopic anthropogenic particles in Skagerrak. Norwegian Environment Agency report TA 2779.

Nuelle, M.-T., Dekiff, J.H., Remy, D. \& Fries, E. (2014). A new analytical approach for monitoring microplastics in marine sediments. Environmental Pollution, 184, pp.161-169. https://doi.org/10.1016/j.envpol.2013.07.027

Näkki, P., Setälä, O. \& Lehtiniemi, M. (2017). Bioturbation transports secondary microplastics to deeper layers in soft marine sediments of the northern Baltic Sea. Marine Pollution Bulletin, 119 (1), pp 255-261. https://doi.org/10.1016/j.marpolbul.2017.03.065

Obbard, R.W., Sadri, S., Wong, Y.Q., Khitun, A.A., Baker, I. \& Thompson, R.C. (2014). Global warming releases microplastic legacy frozen in Arctic Sea ice. Earth's Future, 2(6), pp.315-320. https://doi.org/10.1002/2014EFoo0240

Oberbeckmann, S., Löder, M.G.J. \& Labrenz, M. (2015). Marine microplastic-associated biofilms - a review. Environmental Chemistry, 12(5), p.551. https://doi.org/10.1071/EN15069

Van Der Oost, R., Beyer, J. \& Vermeulen, N.P.E. (2003). Fish bioaccumulation and biomarkers in environmental risk assessment: a review. Environmental Toxicology and Pharmacology, 13, pp.57-149. https://doi.org/10.1016/S1382-6689(02)00126-6

Ory, N.C., Sobral, P., Ferreira, J.L. \& Thiel, M. (2017). Amberstripe scad Decapterus muroadsi (Carangidae) fish ingest blue microplastics resembling their copepod prey along the coast of Rapa Nui (Easter Island) in the South Pacific subtropical gyre. Science of The Total Environment, 586, pp 430-437. https://doi.org/10.1016/j.scitotenv.2017.01.175

OSPAR (2015). OSPAR request on development of a common monitoring protocol for plastic particles in fish stomachs and selected shellfish on the basis of existing fish disease surveys. In ICES Advice 2015, Book 1.

Patwa, A., Thiéry, A., Lombard, F., Lilley, M.K.S., Boisset, C., Bramard, J.-F., Bottero, J.-Y. \& Barthélémy, P. (2015). Accumulation of nanoparticles in "jellyfish" mucus: a bio-inspired route to decontamination of nano-waste. Scientific reports, 5, p.11387.

https://doi.org/10.1038/srep11387 
Perry, M.C., Olsen, G.H., Richards, R.A. \& Osenton, P.C. (2013). Predation on Dovekies by Goosefish Over Deep Water in the Northwest Atlantic Ocean. Northeastern Naturalist, 2O(1), pp.148-154. https://doi.org/10.1656/045.020.0112

Phillips, M.B. \& Bonner, T.H. (2015). Occurrence and amount of microplastic ingested by fishes in watersheds of the Gulf of Mexico. Marine Pollution Bulletin, 100(1), pp.264-269.

https://doi.org/10.1016/j.marpolbul.2015.08.041

Pinnegar, J.K. (2014). DAPSTOM -An Integrated Database \& Portal for Fish Stomach Records. (https://www.europeandataportal.eu/data/en/dataset/dapstom).

Plasticseurope (2016). Plastics - the Facts 2016. An analysis of European plastics production, demand and waste data. (http://www. plasticseurope.org/Document/plastics---the-facts-201615787.aspx?FolID=2).

Potthoff, A., Oelschlägel, K., Schmitt-Jansen, M., Rummel, C.D. \& Kühnel, D. (2017). From the sea to the laboratory: Characterization of microplastic as prerequisite for the assessment of ecotoxicological impact. Integrated Environmental Assessment and Management, 13(3), pp.500-504. https://doi.org/10.1002/ieam.1902

Provencher, J.F., Gaston, A.J., Mallory, M.L., O'hara, P.D. \& Gilchrist, H.G. (2010). Ingested plastic in a diving seabird, the thick-billed murre (Uria lomvia), in the eastern Canadian Arctic. Marine Pollution Bulletin, 6o(9), pp.1406-1411. https://doi.org/10.1016/j.marpolbul.2010.05.017

Rochman, C.M. (2013). Plastics and priority pollutants: a multiple stressor in aquatic habitats. Environmental science \& technology, 47(6), pp.2439-40. https://doi.org/10.1021/es400748b

Rochman, C.M., Browne, M.A., Halpern, B.S., Hentschel, B.T., Hoh, E., Karapanagioti, H.K., Rios-Mendoza, L.M., Takada, H., Teh, S. \& Thompson, R.C. (2013). Policy: Classify plastic waste as hazardous. Nature, 494(7436), pp.169-71. https://doi.org/10.1038/494169a

Rochman, C.M., Hoh, E., Kurobe, T. \& Teh, S.J. (2013). Ingested plastic transfers hazardous chemicals to fish and induces hepatic stress. Scientific reports, 3, p.3263.

https://doi.org/10.1038/srepo3263

Rochman, C.M., Tahir, A., Williams, S.L., Baxa, D. V, Lam, R., Miller, J.T., Teh, F.-C., Werorilangi, S. \& Teh, S.J. (2015). Anthropogenic debris in seafood: Plastic debris and fibers from textiles in fish and bivalves sold for human consumption. Scientific reports, 5, p.14340. https://doi.org/10.1038/srep14340

Romeo, T., Pietro, B., Pedà, C., Consoli, P., Andaloro, F. \& Fossi, M.C. (2015). First evidence of presence of plastic debris in stomach of large pelagic fish in the Mediterranean Sea. Marine Pollution Bulletin, 95(1), pp.358-361. https://doi.org/10.1016/j.marpolbul.2015.04.048

Rummel, C.D., Löder, M.G.J., Fricke, N.F., Lang, T., Griebeler, E.-M., Janke, M. \& Gerdts, G. (2016). Plastic ingestion by pelagic and demersal fish from the North Sea and Baltic Sea. Marine Pollution Bulletin, 102(1), pp.134-141. https://doi.org/10.1016/j.marpolbul.2015.11.043

Ryan, P.G., Moore, C.J., van Franeker, J.A. \& Moloney, C.L. (2009). Monitoring the abundance of plastic debris in the marine environment. Philosophical Transactions of the Royal Society of London B: Biological Sciences, 364(1526). https://doi.org/10.1098/rstb.2008.0207

Raabe, J.K. \& Hightower, J.E. (2014). American Shad Migratory Behavior, Weight Loss, Survival, and Abundance in a North Carolina River following Dam Removals. Transactions of the American Fisheries Society, 143(3), pp.673-688. https://doi.org/10.1080/00028487.2014.882410

Sadove, S.S. \& Morreale, S.J. (1989). Marine mammal and sea turtle encounters with marine debris in the New York Bight and the northeast Atlantic. In S. Shomura and M. L. Godfrey, ed. Honolulu, Hawaii, pp. 562-570.

Santos, J. \& Jobling, M. (1991). Factors affecting gastric evacuation in cod, Gadus morhua L., fed single-meals of natural prey. Journal of Fish Biology, 38(5), pp.697-713.

https://doi.org/10.1111/j.1095-8649.1991.tbo3159.x

Savoca, M.S., Wohlfeil, M.E., Ebeler, S.E. \& Nevitt, G.A. (2016). Marine plastic debris emits a keystone infochemical for olfactory foraging seabirds. Science Advances, 2(11).

https://doi.org/10.1126/sciadv.1600395 
van Sebille, E., England, M.H. \& Froyland, G. (2012). Origin, dynamics and evolution of ocean garbage patches from observed surface drifters. Environmental Research Letters, 7(4), p.44040. https://doi.org/10.1088/1748-9326/7/4/044040

van Sebille, E., Wilcox, C., Lebreton, L., Maximenko, N., Hardesty, B.D., van Franeker, J.A., Eriksen, M., Siegel, D., Galgani, F. \& Law, K.L. (2015). A global inventory of small floating plastic debris. Environmental Research Letters, 10(12), p.124006. https://doi.org/10.1088/17489326/10/12/124006

Setälä, O., Fleming-Lehtinen, V. \& Lehtiniemi, M. (2014). Ingestion and transfer of microplastics in the planktonic food web. Environmental Pollution, 185, pp.77-83. https://doi.org/10.1016/j.envpol.2013.10.013

Shim, W.J., Hong, S.H., Eo, S.E., Peng, J., Li, M., Zhan, Z., Senz, R., Zellers, A., Rifman, S., Guillou, G. Le, Olsen, B., Olsen, K.O., Pedersen, J., Stienen, E.W.M. \& Turner, D.M. (2017). Identification methods in microplastic analysis: a review. Analytical Methods, 9(9), pp.1384-1391. https://doi.org/10.1039/C6AY02558G

Skóra, M., Sapota, M., Skóra, K. \& Pawelec, A. (2012). Diet of the twaite shad Alosa fallax (Lacépède, 1803) (Clupeidae) in the Gulf of Gdansk, the Baltic Sea. Oceanological and Hydrobiological Studies, 41(3), pp.24-32. https://doi.org/10.2478/s13545-012-0024-0

Stelfox, M., Hudgins, J. \& Sweet, M. (2016). A review of ghost gear entanglement amongst marine mammals, reptiles and elasmobranchs. Marine Pollution Bulletin, 111(1-2), pp.6-17. https://doi.org/10.1016/j.marpolbul.2016.06.034

Strand, J., Tairova, Z., Danielsen, J., Hansen, J.W., Magnusson, K., Naustvoll, L. \& Kirk Sørensen, T. (2015). Marine Litter in Nordic waters, Temanord 2015:521. Nordic Council of Ministers. https://doi.org/10.6027/TN2015-521

Sulochanan, B., Bhat, G.S., Lavanya, S., Dineshbabu, A.P. \& Kaladharan, P. (2014). A preliminary assessment of ecosystem process and marine litter in the beaches of Mangalore. Indian Journal of Geo-Marine Sciences, 43.

Sundet, J.H. (2014). The snow crab (Chionoecetes opilio) in the Barents Sea. Report from the Workshop on king- and snow crabs in the Barents Sea, Tromsø 11-12 March 2014, No. 182014 (https://www.imr.no/filarkiv/2014/05/hi-rapp_18-2014_king_and_snow_til_web.pdf/en).

Sundet, J.H., Herzke, D. \& Jenssen, M. (2015). Forekomst og kilder av mikroplastikk i sediment, og konsekvenser for bunnlevende fisk og evertebrater på Svalbard. Sluttrapport Sysselmannen. RIS-prosjekt nr. 10495 .

(http://www.sysselmannen.no/Documents/Svalbard_Miljovernfond_dok/Prosjekter/Rapporter /2016/14-101\%20Sluttrapport\%2oplast_final_2016.pdf).

Sundt, P., Schulze, P.-E. \& Frode, S. (2014). Sources of microplastics-pollution to the marine environment. Norwegian Environment Agency Report no: M-321.

Sussarellu, R., Suquet, M., Thomas, Y., Lambert, C., Fabioux, C., Pernet, M.E.J., Le Goïc, N., Quillien, V., Mingant, C., Epelboin, Y., Corporeau, C., Guyomarch, J., Robbens, J., Paul-Pont, I., Soudant, P. \& Huvet, A. (2015). Oyster reproduction is affected by exposure to polystyrene microplastics. Proceedings of the National Academy of Sciences, 113(9), p.201519019.

Svärd, B. (2013). Ren och Attraktiv kust i Bohuslän - bakgrund och fakta. Strömstad kommun. (http://www.orust.se/download/18.4b24bafo14737bb71e224090/1405429104606/Rapport+Re n+och+attraktiv+kust+-+bakgrund+och+fakta.pdf).

Sørensen, T.K., Stedmon, C., Enders, K. \& Henriksen, O. (2013). Analyse af marint affald $i$ sild og hvilling fra det nordlige Storebælt 2013. DTU AQUA report (https://www.cbd.int/doc/meetings/mar/mcbem-2014-03/other/mcbem-2014-03-020-en.pdf).

Talvitie, J., Heinonen, M., Pääkkönen, J.-P., Vahtera, E., Mikola, A., Setälä, O. \& Vahala, R. (2015). Do wastewater treatment plants act as a potential point source of microplastics? Preliminary study in the coastal Gulf of Finland, Baltic Sea. Water science and technology, 72(9), pp.1495-504. https://doi.org/10.2166/wst.2015.360

Tanaka, K. \& Takada, H. (2016). Microplastic fragments and microbeads in digestive tracts of planktivorous fish from urban coastal waters. Scientific Reports, 6(1), p.34351.

https://doi.org/10.1038/srep34351 
Taylor, M.L., Gwinnett, C., Robinson, L.F. \& Woodall, L.C. (2016). Plastic microfibre ingestion by deep-sea organisms. Scientific Reports, 6(1), p.33997. https://doi.org/10.1038/srep33997

Thompson, R.C., Olsen, Y., Mitchell, R.P., Davis, A., Rowland, S.J., John, A.W.G., McGonigle, D. \& Russell, A.E., 2004. Lost at sea: where is all the plastic? Science, 304(5672), p.838. https://doi.org/10.1126/science.1094559

Trevail, A.M., Gabrielsen, G.W., Kühn, S. \& Van Franeker, J.A. (2015). Elevated levels of ingested plastic in a high Arctic seabird, the northern fulmar (Fulmarus glacialis). Polar Biology, 38(7), pp.975-981. https://doi.org/10.1007/s00300-015-1657-4

Turra, A., Manzano, A.B., Dias, R.J.S., Mahiques, M.M., Barbosa, L., Balthazar-Silva, D. \& Moreira, F.T. (2014). Three-dimensional distribution of plastic pellets in sandy beaches: shifting paradigms. Scientific Reports, 4(1), p.4435. https://doi.org/10.1038/srepo4435

UNEP (2005). Marine Litter, an analytical overview. UNEP Report.

(http://www.cep.unep.org/publications-and-resources/databases/documentdatabase/unep/marine-litter-an-analytical-overview-unep-gpa.pdf/view).

UNEP (2016). Marine plastic debris and microplastics - Global lessons and research to inspire action and guide policy change. United Nations Environment Programme, Nairobi.

(http://apps.unep.org/publications/index.php?option=com_pub\&task=download\&file=012194 _en).

Vandermeersch, G., Van Cauwenberghe, L., Janssen, C.R., Marques, A., Granby, K., Fait, G., Kotterman, M.J.J., Bekaert, K., Robbens, J. \& Devriese, L. (2015). A critical view on microplastic quantification in aquatic organisms. Environmental Research, 143, pp.46-55. https://doi.org/10.1016/j.envres.2015.07.016

Vollertsen, J. \& Aviaja, A. (2017). Microplastic in Danish wastewater Sources, occurrences and fate. Danish Environmental Protection Agency report No. 1906

Watts, A.J.R., Lewis, C., Goodhead, R.M., Beckett, S.J., Moger, J., Tyler, C.R. \& Galloway, T.S. (2014). Uptake and retention of microplastics by the shore crab Carcinus maenas. Environmental science \& technology, 48(15), pp.8823-30. https://doi.org/10.1021/es50109oe

Welden, N.A.C. \& Cowie, P.R. (2016). Long-term microplastic retention causes reduced body condition in the langoustine, Nephrops norvegicus. Environmental Pollution, 218, pp.895-900. https://doi.org/10.1016/j.envpol.2016.08.020

Wesch, C., Bredimus, K., Paulus, M. \& Klein, R. (2016). Towards the suitable monitoring of ingestion of microplastics by marine biota: A review. Environmental Pollution, 218, pp.12001208. https://doi.org/10.1016/j.envpol.2016.08.076

Wójcik-Fudalewska, D., Normant-Saremba, M. \& Anastácio, P. (2016). Occurrence of plastic debris in the stomach of the invasive crab Eriocheir sinensis. Marine Pollution Bulletin, 113(1), pp.306-311. https://doi.org/10.1016/j.marpolbul.2016.09.059

Wright, S.L., Rowe, D., Thompson, R.C. \& Galloway, T.S. (2013). Microplastic ingestion decreases energy reserves in marine worms. Current Biology, 23(23), pp 1031-1033. https://doi.org/10.1016/j.cub.2013.10.068

Wyles, K.J., Pahl, S., Thomas, K. \& Thompson, R.C. (2016). Factors That Can Undermine the Psychological Benefits of Coastal Environments. Environment and Behavior, 48(9), pp.10951126. https://doi.org/10.1177/0013916515592177

Yang, D., Shi, H., Li, L., Li, J., Jabeen, K. \& Kolandhasamy, P. (2015). Microplastic Pollution in Table Salts from China. Environmental Science \& Technology, 49(22), pp.13622-13627. https://doi.org/10.1021/acs.est.5bo3163

Ziajahromi, S., Neale, P.A. \& Leusch, F.D.L. (2016). Wastewater treatment plant effluent as a source of microplastics: review of the fate, chemical interactions and potential risks to aquatic organisms. Water Science and Technology, 74(10), pp.2253-2269

https://doi.org/10.2166/wst.2016.414 



\section{Sammendrag}

På grunn av forurensing av havet, har det vært et behov for forskning som har drevet utviklingen av internasjonale direktiver for å bevare og opprettholde en god miljøstatus. Plast er den største og mest diskuterte komponenten av marint søppel og i denne rapporten diskuterer vi to grupper plastsøppel; makroplast og mikroplast. Den førstnevnte gruppen er store synlige plastartikler, mens sistnevnte er mindre enn $5 \mathrm{~mm}$ i størrelse.

Plastartikler består av forskjellige polymerer og tilsetningsstoffer som gjør plast til et allsidig materiale med mange forskjellige bruksområder. Hovedapplikasjonene i EU inkluderer emballasje samt bygg og anlegg. Den globale produksjonen av plast nådde 322 millioner tonn i 2015, og plastproduksjonen og massekonsumet resulterer til sist i mye avfall. Dersom plastavfallet unnslipper avfallsinnsamlingsordninger eller blir bevisst dumpet i miljøet, blir det plastforurensing. Plast blir funnet i terrestriske, ferskvann og marine miljøer over hele verden.

Det er flere kilder og måter plast ender i det marine miljøet på, f.eks. via elvetransport fra land eller fra sjøbaserte kilder som tap av plast fra fiskerinæringen. Plast finnes i hele havmiljøet, fra urbane strender og svært forurenset kystområder til fjerntliggende steder, inkludert isolerte øyer, på havdypet og i polare områder. Store plastartikler, makroplast, er synlig forurensing som kan sees langs kysten og flytende i overflatevannet. Mikroplast er derimot ikke lett få øye på, men det har blitt dokumentert i alle habitater i både åpne og delvis lukkede havsystemer, inkludert strender, overflatevann, vannsøylen og på dyphavsbunn.

Påvirkning av plast på miljøet inkluderer skader på habitat, tilførsel av ekstra habitater og substrater som kan føre til tilførsel av nye arter, samt mekanisk skade som drukning og annen skade på organismer pluss inntak av plast.

Marine organismer interagerer med mikroplast på flere måter, og interaksjoner kan føre til en rekke negative effekter, eller potensielle effekter som er blitt overvåket under laboratorieundersøkelser. For marin biota i naturen er det imidlertid fortsatt ingen dokumentert sammenheng mellom mikroplastisk interaksjon og negative konsekvenser. Marine organismer påvirkes av flere stressfaktorer i tillegg til mikroplast, som økt temperatur og andre forurensende substanser. Derfor er det utfordrende å isolere mikroplast som den eneste grunnen til en eventuell negativ effekt man finner. Hvis en liten organisme inneholder betydelige mengder mikroplast i forhold til deres størrelse, er det sannsynlig at dette kan ha en negativ innvirkning på vekst eller utvikling. For eksempel kan dette påvirke evnen til å få tilstrekkelig mengder mat. Inntak av mikroplast kan også føre til overføring av adsorberte kjemikalier til biota. Sistnevnte er en pågående debatt, men flere forskere hevder at plast som kilde til kjemikalier er liten sammenlignet med andre eksponeringsveier, som f.eks. byttedyr. 
Dette er derimot fortsatt usikkert, men mye forskning er ventet i tiden fremover på denne problematikken.

Det er mange forskjellige metoder for å etablere tilstedeværelse av plast i biota og metodeutviklingen er pågående. Prøvetaking bør omfatte replikabilitet, sammenlignbarhet, forurensningskontroll samt ta hensyn til ulike miljøparametere under prøvetaking. Ekstraheringsmetoder inkluderer disseksjon av fordøyelseskanaler med visuell inspeksjon og nedbrytningsmetoder med kjemikalier som kaliumhydroksid $(\mathrm{KOH})$ for å bryte ned naturlig organisk materiale. Når partikler man mistenker er plast har blitt separert ut, kan man vurdere disse ut fra deres morfologiske egenskaper, og ved hjelp av analytiske teknikker for å bestemme polymerens kjemiske egenskaper.

Plast forurenser det nordiske havmiljøet til tross for forholdsvis gode avfallshåndteringssystemer i Norge, Sverige, Danmark, Finland og Island. I Norden er det også plast på strendene, i overflatevannet, i vannsøylen, ved og i sediment og til og med i havis. Flere organisasjoner er involvert i strandrydding og det er en økt offentlig bevissthet om plast som miljøproblem i det nordiske havmiljøet. Det nordiske miljøet er forskjellig fra andre geografiske områder, med for eksempel et kaldere klima.

Det meste som finnes av overvåkingsdata som omhandler inntak av plast i biota fra det nordiske havmiljøet, kommer fra sjøfugl. Det er også enkelte rapporter om plastinntak i marine pattedyr fra det nordiske havmiljøet, men disse dataene er bare kvalitative. I de siste årene har det vært et økt fokus på inntak av plast i fisk og virvelløse organismer. Mesteparten av den tilgjengelige litteraturen som omhandler plast i fisk og virvelløse dyr fra nordisk miljø, kommer fra rapporter. Det foreligger bare fire "peerreviewed" publikasjoner. Totalt er det ni studier som har sett på 14 forskjellige fiskearter, hvorav de fleste studiene er gjort i Østersjøen og Nordsjøen. Disse fiskearter er:

- $\quad$ sild (atlanterhavssild og østersjøsild)

- atlanterhavstorsk

- europeisk brisling

- europeisk flyndre

- atlanterhavsmakrell

- tre-pigget stingsild

- sandflyndre

- knurr

- hvitting

- taggmakrell

- hyse

- ålekrabbe

- dvergulke

- stamsild. 
Disse fiskeartene er pelagiske eller demersale arter fra kyst- og offshore-lokaliteter. Sild og torsk er de mest studerte artene både basert på antall og antall studieområder. Prosentandelen av plastinntak varierte fra o-30 \%, 13-47\% og o-31\% i henholdsvis sild, torsk og makrell.

Det er svært få studier på mikroplastinntak hos muslinger og andre virvelløse dyr fra det nordiske havmiljøet. Blåskjell er den mest studerte virvelløse biotaen med fire studier og totalt 205 individer studert fra Danmark, Sverige, Skagerrak og Svalbard. For tiden eksisterer det bare én studie med fem blåskjellindivider som omhandler forekomst av mikroplast i biota fra akvakultur i det nordiske miljøet. I alt er det tre studier som omhandler bentisk biota - plast ble funnet i marine ormer fra Nordsjøen, snøkrabbe fra Barentshavet og i ullhåndskrabbe fra Østersjøen. Det finnes også upubliserte rapporter om plast funnet i avføring fra slangestjerner og flerbørstemark fra svenske farvann.

Sammenligning mellom og innenfor studier fra det nordiske miljø og andre regioner er utfordrende da det er 1 ) et begrenset antall studier, 2) begrenset antall studier på samme art fra forskjellige steder og 3) forskjellige metoder som er benyttet. Flere andre faktorer kan også påvirke nivået av plastinntak i arter, spesielt for fisk. Artenes ulike økologi kan påvirke deres sjanse for interaksjon med plast, for eksempel kan demersale arter bli mer utsatt for sedimentert plast enn de som tar til seg føde i vannsøylen. Opptak kan også være relatert til avstand fra urbaniserte steder, avstand fra plastkilder eller akkumuleringsområder. Trofisk nivå, alder, størrelse og reproduksjonssyklus kan også påvirke plastinntaket. I tillegg kan magefyll (tid siden sist fødeinntak) påvirke mengde plast funnet, noe som kan gi oss bare et "snapshot" i tiden når vi analyserer fisk.

For å forstå hvilken innvirkning plastforurensing har på det marine miljøet og biota, er det viktig å overvåke inntak og eventuelle effekter. Derfor kan såkalte biomarkører eller bioindikatorer brukes til å overvåke påvirkningen av plast på biota. Når man skal diskuterer egnede fiskearter for det nordiske miljøet, er det et begrenset datamateriale til dags dato som ligger til grunn for å gi tilstrekkelig anbefalinger. Det foreslås derfor at nordiske land undersøker flere fiskearter med flere individer, fra både pelagiske og demersale miljøer for å få bedre oversikt over nivåer av plastinntak. Det er imidlertid viktig å gjøre det med sammenlignbare metoder. Torsk, sild og makrell, en demersal og to pelagisk arter, er aktuelle arter som har en tilstrekkelig tilstedeværende og er kommersielt viktig i Norden, og bør vurderes til bruk for overvåking av plastpåvirkning på fisk. Muslinger oppfyller mange av kriteriene som kreves for en biomonitor art, og noen av de viktigste fordelene over fisk er at de er sessile og mye lettere å håndtere, samt at det er mer standardiserte metoder tilgjengelig. Blåskjell har også tidligere blitt foreslått for å overvåke mikroplast fordi de har en klar definert økologisk nisje, og de er tilstedeværende $\mathrm{i}$ hele det nordiske miljøet, samt at de brukes til andre overvåkingsstudier. Siden sediment kan være et oppsamlingssted for plastforurensning, har sediment-levende organismer, spesielt flerbørstemarker, et stort potensiale for å kunne brukes til plastovervåking. Arenicola marina er foreslåes som en egnet art fordi den allerede er brukt til overvåkning, samt at laboratorieundersøkelser allerede har vist at den kan påvirkes av mikroplasteksponering. 
I et mattrygghetsperspektiv er tilstedeværelse av, og muligheten for eksponering for mikroplast gjennom sjømat, en kilde til bekymring for mange forbrukere. Mikroplast har blitt funnet i fisk og skalldyr som er kommersielt tilgjengelig, hvorav noe, som blåskjell, blir konsumert hele. Matvarer som er forurenset av mikroplast, har et potensiale til å overføre plastrelaterte kjemikalier til mennesker. Nåværende ekspertvurderinger tyder på at mikroplast i fisk og skalldyr ikke utgjør en betydelig risiko for menneskers helse. Det er derimot fortsatt knyttet stor usikkerhet til dette. Det er for eksempel knyttet mye usikkerhet til effekten av nanoplast i matvarer. Med hensyn til mattrygghet er det nødvendig å fastslå nivåene som finnes i ulike kommersielt viktige arter, og også å forstå hvilke farer dette kan ha for mennesker.

Det er flere store kunnskapshull når det gjelder nivåer av mikroplast i nordisk marin biota, både geografisk, men også med hensyn til ulike arter. De mest studerte områdene er Nordsjøen og Østersjøen, med få studier fra Skagerrak, Kattegat og nord i det nordiske området. Det er også meget få studier fra havområdene vest og nord for Færøyene, inkludert områder rundt Island og Grønland.

Sjøfugl fra det nordiske havmiljøet brukes til å overvåke plast ned til $1 \mathrm{~mm}$. Det er imidlertid ingen data på mikroplast mindre enn $1 \mathrm{~mm}$. Derfor bør også overvåkning av mikroplast mindre enn $1 \mathrm{~mm}$ inkluderes for sjøfugl.

For fisk er det noen data om inntak av mikroplast i pelagiske og demersale fiskearter, men det er begrenset datagrunnlag og kunnskap om mulige effekter. Det er et behov for å øke mengden data for de forskjellige fiskeartene, ved hjelp av standardiserte metoder slik at det er mulig å foreta nøyaktige sammenligninger mellom studier. Det er ingen data som omhandler tidlige stadier av fisk, fiskelarver, og hvordan disse eventuelt kan bli påvirket av mikroplast.

For tiden er det ingen informasjon om fytoplankton eller zooplankton som omhandler inntak eller annen påvirkning av mikroplast fra det nordiske havmiljøet. Det er viktig å studere organismer fra lavere trofiske nivå da de er basisen i næringskjeden.

I tillegg er det ingen data for nesledyr, svamper eller koraller. Siden mye mikroplast i havmiljøet er forbundet med sedimentene, er det også viktig å studere sedimentlevende organismer. Veldig lite informasjon er tilgjengelig på flerbørstemark, med kun noen få preliminære studier som har sett på Arenicola marina. For leddyr er det også begrenset tilgjengelig data og det er viktig å forstå effekter av mikroplast på viktige grupper innen leddyr som krepsdyr. For muslinger er det noen studier på blåskjell, men data er begrenset også her. I tillegg til blåskjell, som er filtrende, er det også mange andre viktige muslinger som har forskjellige fôringsmekanismer, og som derfor kan bidra til en bredere forståelse av plasteksponering for denne gruppen av organismer. Ingen informasjon er tilgjengelig for snegler eller blekksprut. Videre er det utilstrekkelig kunnskap om mikroplast i marine pattedyr fra det nordiske havmiljøet, og siden de står øverst i næringskjeden, kan de være indikatorer for hvorvidt trofisk overføring skjer. 
Kunnskapshull - geografisk:

- Nordsjøen og Østersjøen er de mest studerte havområdene.

- Få studier er utført i Skagerrak, Kattegat, og vest og nord i det nordiske havmiljøet. Det er også meget få studier fra havområdene vest for Færøyene, inkludert områder rundt Island og Grønland.

Kunnskapshull - biota:

- Organisering av diskusjonsfora for å diskutere egnede metoder for overvåkning av mikroplastisk i biota. I tillegg til å diskutere egnede metoder, bør fokus også være på å håndtere skjevheter som kan oppstå som følge av magevolum (matinntak) for fisk, generell subjektivitet i metoder og kvalitetskontroll, kontroll for forurensing av prøver m.m.

- Metodeutvikling for å få en lavere deteksjonsgrense. Deteksjonsgrensen vanligvis 200 til $100 \mu \mathrm{m}$.

- Harmonisering og standardisering av metoder som brukes til å undersøke mikroplast i biota.

- Inter-kalibrering mellom laboratorier med f.eks. ringtest for å lære om variasjoner mellom laboratorier.

- Identifisering av egnede arter for overvåking for ulike habitater. For eksempel identifisering av pelagiske og bentiske fiskearter fra kyst- og offshore lokaliteter.

- $\varnothing k e$ antall dyrerekker som har blitt studert for mikroplast inntak fra det nordiske havmiljøet.

- Studere inntak av mikroplast i arter fra lavere trofiske nivåer.

- Studere inntak av mikroplast i høyere trofiske nivåer (bortsett fra sjøfugl).

- Øke antall studier for alle dyrerekker, også for de som allerede er studert til en viss grad, spesielt for virvelløse dyr.

- Undersøke mikroplastinntak i samme art med samme metoder for ulike områder, for å kunne se på spatiale og temporale trender.

- Allerede eksistrenede plast-overvåkingsprosjekter bør inkludere mindre mikroplastpartikler. For eksempel er den nedre størrelsesgrensen for tiden $1 \mathrm{~mm}$ for overvåking av sjøfuglen havhest under OSPAR.

- Mikroplaststudier av biota fra flere steder i det nordiske havmiljøet kreves for bedre å forstå påvirkning og nivåer. 

Appendix 
Table 13: Study ID corresponds to figures 13-17

\begin{tabular}{|c|c|c|c|c|c|c|c|c|c|}
\hline Study ID & Species name & Species Latin name & Sea & Year & Most dominant polymers & $\mathrm{n}$ & $\%$ containing MPs & Type of reference & Reference \\
\hline$A C-01$ & Atlantic cod & Gadus morhua & North Sea & 2013 & PE and PP & 67 & 14,9 & Scientific & Foekema et al. \\
\hline AC-02 & Atlantic cod & Gadus morhua & North Sea & 2013 & 1 & 13 & 0,0 & Scientific & Foekema et al. \\
\hline AC-03 & Atlantic cod & Gadus morhua & North Sea & 2015 & $\mathrm{PE}$ and $\mathrm{PA}$ & 7 & 0,0 & Scientific & Rummel et al \\
\hline AC-04 & Atlantic cod & Gadus morhua & North Sea & 2015 & I & 28 & 14,3 & Report & Lenz et al. \\
\hline AC-05 & Atlantic cod & Gadus morhua & North Sea & 2015 & I & 72 & 48,6 & Report & Lenz et al. \\
\hline AC-o6 & Atlantic cod & Gadus morhua & Norwegian Sea & 2016 & Polypropylene (PP) & 12 & 8,3 & Scientific & Bråte et al. \\
\hline AC-07 & Atlantic cod & Gadus morhua & North Sea & 2016 & Polyester (PCT)), Polyvinyl chloride (PVC) & 30 & 26,7 & Scientific & Bråte et al. \\
\hline AC-08 & Atlantic cod & Gadus morhua & North Sea & 2016 & I & 50 & 0,0 & Scientific & Bråte et al. \\
\hline AC-og & Atlantic cod & Gadus morhua & Norwegian Sea & 2016 & I & 56 & 0,0 & Scientific & Bråte et al. \\
\hline$A C-10$ & Atlantic cod & Gadus morhua & Barents Sea & 2016 & I & 58 & 0,0 & Scientific & Bråte et al. \\
\hline$A C-11$ & Atlantic cod & Gadus morhua & Skagerrak & 2016 & l & 96 & 0,0 & Scientific & Bråte et al. \\
\hline AC-12 & Atlantic cod & Gadus morhua & Baltic Sea & 2013 & I & 16 & Yes - do not know \% & BSc thesis & Agersnap \\
\hline$A C-13$ & Atlantic cod & Gadus morhua & Baltic Sea & 2015 & l & 50 & 26,0 & Report & Lenz et al. \\
\hline $\mathrm{AC}-14$ & Atlantic cod & Gadus morhua & Baltic Sea & 2015 & I & 51 & 15,7 & Report & Lenz et al. \\
\hline$A C-15$ & Atlantic cod & Gadus morhua & Baltic Sea & 2015 & $\mathrm{PE}$ and PA & 338 & 1,4 & Scientific & Rummel et al \\
\hline $\mathrm{AH}-01$ & Atlantic herring & Clupea harengus & North Sea & 2013 & $\mathrm{PE}$ and $\mathrm{PP}$ & 116 & 1,7 & Scientific & Foekema et al. \\
\hline $\mathrm{AH}-02$ & Atlantic herring & Clupea harengus & North Sea & 2013 & 1 & 450 & 0,4 & Scientific & Foekema et al. \\
\hline $\mathrm{AH}-\mathrm{O} 3$ & Atlantic herring & Clupea harengus & North Sea & 2015 & I & 50 & 30,0 & Report & Lenz et al. \\
\hline $\mathrm{AH}-\mathrm{O}_{4}$ & Atlantic herring & Clupea harengus & North Sea & 2015 & I & 50 & 16,0 & Report & Lenz et al. \\
\hline $\mathrm{AH}-05$ & Atlantic herring & Clupea harengus & North Sea & 2015 & $\mathrm{PE}$ and $\mathrm{PA}$ & 102 & 0,0 & Scientific & Rummel et al \\
\hline AH-o6 & Atlantic herring & Clupea harengus & Kattegat & 2013 & 1 & 45 & 27,0 & Report & Sørensen et al \\
\hline $\mathrm{AH}-07$ & Atlantic herring & Clupea harengus & Baltic Sea & 2015 & I & 55 & 7,3 & Report & Lenz et al. \\
\hline $\mathrm{AH}-08$ & Atlantic herring & Clupea harengus & Baltic Sea & 2015 & l & 50 & 16,0 & Report & Lenz et al. \\
\hline AH-og & Atlantic herring & Clupea harengus & Baltic Sea & 2015 & $\mathrm{PE}$ and $\mathrm{PA}$ & 58 & 0,0 & Scientific & Rummel et al \\
\hline$A H-10$ & Baltic herring & Clupea harengus & Baltic Sea & 2016 & Unknown & 299 & 21,0 & MSc thesis & Beer 2016 \\
\hline $\mathrm{AH}-11$ & Baltic herring & Clupea harengus & Baltic Sea & 1 & Unknown & 150 & 1,8 & Unpublished data & Badumir et al. (unpublished) \\
\hline AM-01 & Atlantic mackerel & Scomber scombrus & North Sea & 2013 & 1 & 84 & 0,0 & Scientific & Foekema et al. \\
\hline AM-02 & Atlantic mackerel & Scomber scombrus & North Sea & 2015 & PE and PA & 172 & 13,2 & Scientific & Rummel et al. \\
\hline AM-03 & Atlantic mackerel & Scomber scombrus & Baltic Sea & 2015 & $\mathrm{PE}$ and $\mathrm{PA}$ & 191 & 17,7 & Scientific & Rummel et al. \\
\hline ES-01 & European sprat & Sprattus sprattus & Baltic Sea & 2016 & Unknown & 515 & 18,0 & MSc thesis & Beer 2016 \\
\hline ES-02 & European sprat & Sprattus sprattus & Baltic Sea & l & Unknown & 100 & 0,9 & Unpublished data & Badumir et al. (unpublished) \\
\hline HM-01 & Horse mackerel & Trachurus trachurus & North Sea & 2013 & PE and PP & 100 & 1,0 & Scientific & Foekema et al. \\
\hline TS-01 & Three-spined sticklebacks & Gasterosteus aculeatus & Baltic Sea & l & Unknown & 350 & 0,0 & Unpublished data & Badumir et al. (unpublished) \\
\hline
\end{tabular}




\begin{tabular}{|c|c|c|c|c|c|c|c|c|c|}
\hline Study ID & Species name & Species Latin name & Sea & Year & Most dominant polymers & $\mathrm{n}$ & $\%$ containing MPs & Type of reference & Reference \\
\hline TW-01 & Twaite shad & Alosa fallax & Baltic Sea & 2012 & I & 1 & Yes - do not know \% & Scientific & Skóra et al. \\
\hline CD-o1 & Common dab & Limanda limanda & North Sea & 2015 & PE and PA & 74 & 54,0 & Scientific & Rummel et al \\
\hline CD-02 & Common dab & Limanda limanda & Baltic Sea & 2015 & PE and PA & 98 & 0,0 & Scientific & Rummel et al \\
\hline EE-01 & European eelpout & Zoarces viviparus & Baltic Sea & 2013 & l & 30 & Yes - do not know $\%$ & BSc thesis & Agersnap \\
\hline EE-02 & European eelpout & Zoarces viviparus & Baltic Sea & 2013 & l & 30 & Yes - do not know \% & BSc thesis & Agersnap \\
\hline EF-01 & European flounder & Platichthys flesus & North Sea & 2015 & $\mathrm{PE}$ and PA & 256 & 0,0 & Scientific & Rummel et al \\
\hline EF-02 & European flounder & Platichthys flesus & Baltic Sea & 2015 & PE and PA & 299 & 10,0 & Scientific & Rummel et al \\
\hline GG-01 & Gray gurnard & Eutrigla gurnardus & North Sea & 2013 & $\mathrm{PE}$ and PP & 171 & 0,0 & Scientific & Foekema et al. \\
\hline HA-01 & Haddock & Melanogrammus aeglefinus & North Sea & 2013 & l & 97 & 6,2 & Scientific & Foekema et al. \\
\hline LB-01 & Longspined bullhead & Taurulus bubalis & Baltic Sea & 2013 & l & 7 & Yes-do not know \% & BSc thesis & Agersnap \\
\hline WH-01 & Whiting & Merlangius merlangus & North Sea & 2013 & $\mathrm{PE}$ and PP & 105 & 5,7 & Scientific & Foekema et al. \\
\hline WH-02 & Whiting & Merlangius merlangus & Kattegat & 2013 & l & 46 & 31,0 & Report & Sørensen et al \\
\hline SC-01 & Snow crab & Chionoecetes opilio & Barents sea & & & l & 20,0 & Report & Sundet \\
\hline CC-01 & Chinese mitten crab & Eriocheir sinensis & Baltic Sea & & & 50 & 28,0 & Scientific & Wójcik-Fudalewska \\
\hline CC-02 & Chinese mitten crab & Eriocheir sinensis & Baltic Sea & & & 208 & 9,0 & Scientific & Wójcik-Fudalewska \\
\hline IC-01 & Iceland Cockle & Clinocardium ciliatum & Greenland sea & & & 10 & 0,0 & Report & Herze \\
\hline BM-01 & Blue mussels* & Mytilus spp & Greenland sea & & & 10 & 20,0 & Report & Herze \\
\hline BM-02 & Blue mussel & Mytilus edulis & Kattegat & & & 120 & 66,7 & BSc thesis & Gustafsson \\
\hline BM-03 & Blue mussel & Mytilus edulis & Limfjorden & & & 5 & 0,0 & Scientific & Vandermeersch \\
\hline BM-04 & Blue mussel & Mytilus edulis & Baltic Sea & & & 30 & Yes-do not know \% & BSc thesis & Agersnap \\
\hline BM-05 & Blue mussel & Mytilus edulis & Baltic Sea & & & 30 & Yes-do not know \% & BSc thesis & Agersnap \\
\hline MW-01 & Polychaeta & Arenicola marina & North Sea & & & l & Yes-do not know \% & Preliminar results & Haave \\
\hline MW-02 & Polychaeta & Chaetozone jubata & North Sea & & & l & Yes-do not know \% & Preliminar results & Haave \\
\hline MW-03 & Polychaeta & Pectinaria belgica & North Sea & & & I & Yes-do not know \% & Preliminar results & Haave \\
\hline MW-04 & Polychaeta & Pectinaria auricoma & North Sea & & & 1 & Yes-do not know \% & Preliminar results & Haave \\
\hline
\end{tabular}




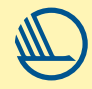

Nordic Council of Ministers

Nordens Hus

Ved Stranden 18

DK-1061 Copenhagen $\mathrm{K}$

www.norden.org

\section{Micro-and macro-plastics in marine species from Nordic waters}

This report summarises the knowledge on plastics in Nordic marine species.

Nordic biota interacts with plastic pollution, through entanglement and ingestion. Ingestion has been found in many seabirds and also in stranded mammals. Ingestion of plastics has been documented in 14 fish species, which many of them are of ecology and commercially importance. Microplastics have also been found in blue mussels and preliminary studies found synthetic fibres in marine worms. Comparability between and within studies of plastic ingestion by biota from the Nordic environment and other regions are difficult as there are: few studies and different methods are used. It is important that research is directed towards the knowledge gaps highlighted in this report, to get a better understanding on plastic ingestion and impact on biota from the Nordic marine environment 